\title{
日本に括汗る大雨の気候学的研究
}

\author{
奥田穣

\section{Climatological Study on Heavy Rainfalls in Japan}

\author{
by \\ Minoru Okuta \\ Meteorological Research Institute, Tokyo \\ (Received April 28, 1970)
}

\begin{abstract}
\section{Introduction}

In this study, the climatological characteristics of heavy rainfalls in Japan are investigated on the basis of the frequency distribution of heavy rainfalls which is calculated from the daily precipitation amount for each of the following classes: $\geqq 50 \mathrm{~mm}, \geqq 100 \mathrm{~mm}, \geqq 150 \mathrm{~mm}$, $\geqq 200 \mathrm{~mm}, \geqq 300 \mathrm{~mm}, \geqq 400 \mathrm{~mm}, \ldots$. In the first chapter, the climatological characteristics of heavy rainfalls are examined statistically, and the second, their areal characteristics are studied from the standpoint of dynamic climatology.
\end{abstract}

The reason why we take up the frequency of heavy rainfalls and classify the daily precipitation amounts as above is as follows: (1) the classes of daily precipitation amount correspond with the scale of flood disaster; (2) when we use the precipitation amount, we can not grasp the climatological characteristics unless we treat the rainfall intensity coincident with it; (3) variations of monthly and annual precipitation amount do not always coincide with those of the frequency of heavy rainfalls. Particularly in the case of a daily precipitation amount of more than $100 \mathrm{~mm}$ we must treat the frequency rather than the precipitation amount itself; and (4) the frequency is easier to treat statistically than the amount.

The statistics cover the period of ten years 1951-60, and we use the data of 137 meteorological offices and stations where raingauge observation was done for the whole period. For the discussion of the details of areal characteristics, we use the data of the entrusted raingauge stations for the 10-year period of 1952-61 (except for 8 months from September 1952 to April 1953).

(The present paper partly overlaps the author's previous paper 
(Climatological Characteristics of Heavy Rains in Japan (1) (1968) ) and Figures and Tables contained there are omitted here.)

\section{Statistical study of heavy rainfalls}

Total frequencies of daily precipitation amount at every station for each of the classes $\geqq 0.1 \mathrm{~mm}, \geqq 1.0 \mathrm{~mm}, \geqq 5.0 \mathrm{~mm}, \geqq 10 \mathrm{~mm}, \geqq 30 \mathrm{~mm}$, $\geqq 50 \mathrm{~mm}, \geqq 100 \mathrm{~mm}, \geqq 150 \mathrm{~mm}, \geqq 200 \mathrm{~mm}, \geqq 300 \mathrm{~mm}, \geqq 400 \mathrm{~mm}$ and $\geqq 500 \mathrm{~mm}$ are found to be expressed by some exponential function.

The frequency distribution of classified daily precipitation amount for each station has a peculiar form corresponding to the locality's climatic type of heavy rainfalls, the details of which are to be described later. And to get stable frequency distribution of precipitation, statistical data for a period longer than 50 year's are required.

The areal distribution of the total of heavy rainfalls during those ten years is studied for each class. Further, the seasonal variation of the areal frequency distribution of heavy rainfalls of $\geqq 50 \mathrm{~mm}$ and $\geqq 100 \mathrm{~mm}$ is examined. The characteristics of the areal frequency of distribution are as follows:

(1) The Japanese Islands are divided into several zones each one degree of latitude wide, and latitudinal ten-year mean frequencies of heavy rainfalls are calculated according to the frequencies of every station in each latitudinal zone. The latitudinal mean frequency of ten-year mean heavy rainfalls of every station in each one degree of latitude shows a characteristic distribution which corresponds to the latitudinal variation of the distribution of water vapour contents; there is a border lines in the frequency distributions at about $37^{\circ} \mathrm{N}$ for $\geqq 50 \mathrm{~mm}$ and at about $36^{\circ} \mathrm{N}$ for $\geqq 100 \mathrm{~mm}$ : to the north of this line the latitudinal variation of the frequency distribution of heavy rainfall is small and to the south of it increases remarkably as we go southwards.

(2) The season with frequent heavy rainfalls is from June to October, that is, from Bai-U to Typhoon Season. Its supplemental characteristic features are that in April heavy rainfalls are rather frequent and that their frequency is high in winter in the region of heavy snowfalls along the coast of the Japan Sea.

(3) Remarkable characteristics of the frequency distribution are as follows; (a) In peninsulas and islands situated on the Pacific side the frequency of heavy rainfalls is higher on the east side than on the west side of them. (b) In the central part of the Inland Sea of Seto, in the coastal region of Holkkaido facing the Sea of Okhotsk and in the northern part of the inland area of the Chubu District, the frequency of heavy rainfalls is considerably low. (c) High frequency areas appear along the coast of the Pacific Ocean, and considerably high frequent areas appear on the east side of the Izu and the Kii Peninsulas, and in the inland area and east coast of the Kyushu District. 
(4) Areas with a high frequency of heavy rainfalls of classes above $200 \mathrm{~mm}$ in daily precipitation amount are restricted to those which are characterized not only by abundant water vapour inflow but also by frequent passages of meteorological disturbances.

(5) According to the seasonal variation of frequency and the total number of heavy rainfalls of each station, we can classify the heavy rainfalls in Japan into four climatic types and some transitional ones:

Type I with low frequency throughout the year; the frequency of heavy rainfalls more than $50 \mathrm{~mm}$ in daily precipitation amount is less than 30 days in 10 years, heavy rainfalls occurring only in the warm season (Hokkaido except the southeast Pacific coast, the coastal region of Aomori Bay, the inland area extending from Yamagata Prefecture to Fukushima Prefecture a little nearer to the Pacific Ocean, the Nagano Basin and the central part of the Inland Sea of Seto).

Type II with high frequency throughout the year; the frequency is more than 80 days, heavy rainfalls appearing throughout the year (the coastal regions along the Pacific Ocean).

Type III with high frequency in winter; the maximum in the year appears in the season of winter monsoon but heavy rainfalls more than $100 \mathrm{~mm}$ are rather frequent in the warm season (the coast along the Japan Sea).

Type IV with high frequency in the warm season; the frequency is more than 80 days, heavy rainfalls appearing only in the warm season (the inland area of Kyushu and the mountainous region of the northern Kanto District).

Transitional Types; Type I to Type II (the coast of the Bungo and the Kii Channel, the southern part of the inland area of the Kanto and the Chubu District), Type I to Type III (the Japan Sea coast from the Hokkaido District to the Tohoku District)'.

(6) Then, combining those types and comparing frequencies of heavy rainfalls between the Bai-U and the Typhoon Season or between June and July by using the data of the entrusted rain-gauge stations in the western part of Japan, it is suggested that subdivision of the climatic provinces of heavy rainfalls is possible.

The climatic provinces of heavy rainfalls that we suggested in this paper very well coincide with the climatic provinces proposed by E. Fukui (1933).

\section{Dynamic climatological study of heavy rainfalls}

(1) Relation between frequency of heavy rainfalls and rainfall density: 
From the fact that the distribution type of frequencies of each class of daily precipitation amount from $\geqq 0.1 \mathrm{~mm}$ to $\geqq 500 \mathrm{~mm}$ at each station is expressed by some exponential function, it is proved theoretically that rainfall density can be an index to the frequency of heavy rainfalls. But the relation between rainfall density and frequency of heavy rainfalls is different by the climatic type of heavy rainfalls. So, if one wants to take up the rainfall density as an index to the frequency of heavy rainfalls, he should make an accurate classification of the climatic provinces of heavy rainfalls, and then the relationships between the rainfall density and frequency of heavy rainfalls which are obtained for respective climatic provinces of heavy rainfalls should be applied to his purpose.

(2) Relations between the altitude and the frequency of heavy rainfalls:

The frequency of heavy rainfalls in mountainous regions is about one and a half times that in the adjacent level land. This phenomenon is explained by the forced accent effect of wet air currents due to mountainous topography.

(3) Primary conditions causing areal characteristics of heavy rainfalls :

The primary conditions causing the areal characteristics of heavy rainfalls may be divided roughly into two as follows:

(A) Whether or not large quantities of water vapour are supplied continuously into a certain area.

(B) Whether or not strong ascending currents occur continuously in a certain area.

(A) The frequency of heavy rainfalls as controlled by water vapour contents:

The water vapour content in the atmosphere is controlled mainly by temperature and also affected by the distributions of ocean currents. The fact that the frequency of heavy rainfalls increases rapidly as one goes southward from the border line at about $36^{\circ}-37^{\circ} \mathrm{N}$ is caused by the latitudinal distribution of the water vapour content. In the area with less than $13 \mathrm{mb}$ of annual mean water vapour pressure the variation of the frequency of heavy rainfalls with latitude is small, and in the area with more than $13 \mathrm{mb}$ it is large.

Supply of water vapour into the atmosphere is done by the process of evaporation, and the higher the sea-surface temperature rises above the atmospheric temperature, the more is the evaporation generated. So, water vapour is supplied into the atmosphere over Japan in the area of warm ocean currents in the South Seas and Japanese waters, and areas of frequent heavy rainfalls are naturally found in regions where the wet air current can easily flow in after having been modified during its passage over the warm ocean current for a long time and distance.

The areas of extremely low frequency, such as the northern part 
of Nagano Prefecture and the central part of the Inland Sea of Seto, are under the influence of the screening effect of mountains upon the wet air current flowing in from the ocean. As an example of this, we showed the relation between the wind direction at $850 \mathrm{mb}$ level and the difference of frequency of heavy rainfalls on the east and the west side of the Kii Peninsula.

(B) Primary conditions causing the asending current:

The conditions causing the ascending current are considered under the following four heads:

i) Meteorological disturbance on a synoptic scale is strong.

ii) Stratification of the atmosphere is unstable.

iii) Dissolution of convective instability concentrates locally.

iv) Forced ascending current is produced by orographic effect and strong forced convergence occurs.

Those four conditions are examined closely in relation to the areal characteristics of heavy rainfalls. Meteorological disturbances on a synoptic scale are responsible for the areal characteristics and the seasonal variation of the frequency of heavy rainfalls. It is shown that the seasonal variation of heavy rainfalls can be explained by that of the circulation systems in East Asia suggested by A. KuRASHIMA (1968).

Near cyclones and fronts, the stratification of the atmosphere is unstable, and the areal concentration of the dissolution of convective instability appears frequently in the western part of Japan at the time when the wet air current flows into that area in the shape of a tongue at the edge of an anti-cyclone of the North Pacific Ocean. The heavy snowfalls on the Japan Sea coast in winter are caused by the dissolution of convective instability accumulated gradually in the cold air mass as it crosses the Japan Sea.

In addition to the screening effect of mountains upon the transportation of water vapour contents, there are the following effects of topography upon the areal characteristics of heavy rainfalls:

a) Forced ascending current due to mountainous topography

b) Ascending by forced convergence due to topography

c) Ascending by forced convergence caused by relief

d) Rapid decay of meteorological disturbances by relief

Among these effects, a)', b) and d) have been examine by many researchers up to now. The effect of c) has not yet been examined sufficiently, except that T. BERGERoN (1959) tried to explain it by orographically conditioned convergence and C. W. NEWTON (1959) discussed about it.

The author explains the formation of the zone of frequent heavy rainfalls near the coastal region and at the edge of a mountainous region by forced convergence caused by the difference of roughness between land and sea or plain and mountain. A good example of the zone of frequent heavy rainfalls by this roughness effect is found 
along the coast of the Kii Peninsula at a distance of $20-25 \mathrm{~km}$ from the seashore.

Lastly, the author shows that there are also areal characteristics in the diurnal variation of the frequency of rainfall intensites of more than $10 \mathrm{~mm}$ per hour at the time of heavy rainfalls. The maximum appears at about sunrise in the coastal region and in the afternoon in the inland area. This fact runs counter to the theory of H. LANDSBERG (1950) and others. It is pointed out that the variation of the local circulation caused by the diurnal variation of heat budget has some influence on the diurnal variation of rainfall intensity at the time of heavy rainfalls, too. 


\section{目次}

1.はしがき

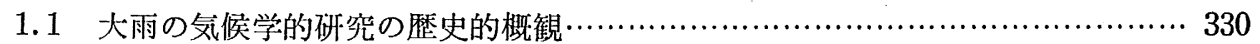

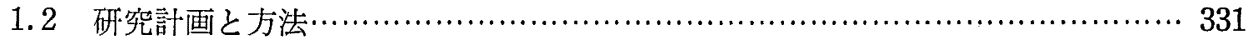

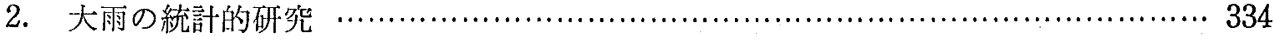

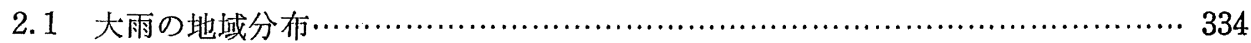

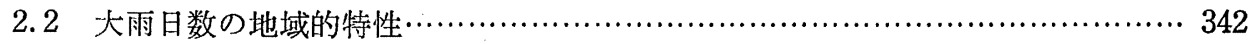

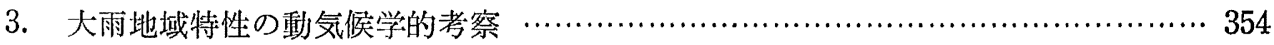

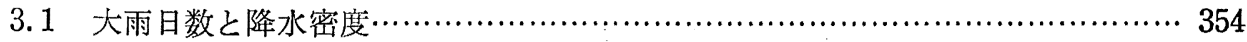

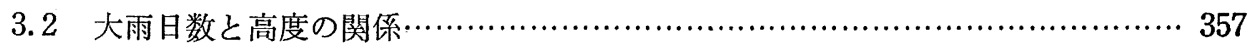

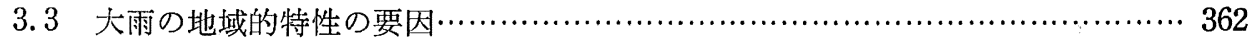

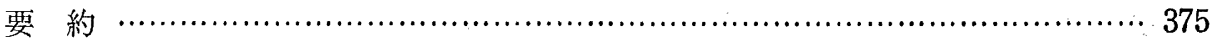




\section{1. は $し$ がき}

\section{1 大雨の気候学的研究の歴史的概観}

降水要素を用いて，日本に特ける降雨の気候学的特性を研究したものは数多い。たとえば, 福井英一郎 (1934) は日本に打ける降水変化量を論じ，矢沢大二(1949) は降水量の量的な局 地性について, 関口武 $(1944,49)$ は総降水日数に刘する $1.0 \mathrm{~mm}$ 以下の微雨日数の占める割合 の分布怙よび，年降水日数の分布型について検討を加えている。また，土屋正孝 (1960) は, 月および年の $1.0 \mathrm{~mm}$ 以上の降水日数で同期間の総降水量を除した值，すなわち降水密度によっ て地域区分を試みた。吉野正敏 (1960) は10分ないし36時間の各時間雨量の雨量一特間曲線等 の地域分布特性を論じ, 雨量強度の算出実験式に関する綿密な吟味を行なった。

さらに最近になって, 関口武らによって東京扔よび 関東地方の大雨に関する研究が行なわれ ているし $(1965,67)$, 水越允治 (1962) は, 梅雨期に多雨の出現度数の多い地域が南南西ない し西南西の湿潤気流の, 山岳地形によって遮蔽されない地域と一致すると主張した。また, 福 井英一郎 (1967) は，日降水量が年降水量の 10\% 以上になった時の雨を集中豪雨とし，集中豪 雨の出現度数の年変化拉よび経年変化を検討し, 集中豪雨の多発域が大体一定していることを 指摘している。

これらの研究のうち，大雨日数を直接取り扱っている研究は関口らの一連の研究である。関 口らは, 「東京の大雨の気候学」に拈いて, 日雨量を単位要素とし, 月別雨量階級別度数分布に よって，東京の大雨が 秋の台風期に多いことを示し，その大雨の気象的原困を吟味して，100 $\mathrm{mm}$ 以上の大雨の大部分が台風によるものであることを明らかにし, さらに, 雨量分布型から, 地形性 レインバンド型, 全域型, 前線型, 海岸型, 分散型の 5 類型を導いた。関口らは「関東 地方の大雨の気候学」に抽いて，さらに同じ手法によって研究を進めている。

外国に和ける研究について見ると，降水に関する気候学的研究は数多くあり，枚挙にいとま がないが，われわれの研究，すなわら大雨に関係する気候学的研究にしぼって概観することと する。

大雨に関する研究となると，外国でも一般に大雨の確率分布から再現期間に関するものが多 くなっている。そのなかで，L. REICHMANN (1964) は，北部ザクセン平野部に括ける豪雨拉 よび長雨を取り上げて，気候学的研究にまで立ら入って研究を進めている。すなわち，1 級観測 所39地点, 2 級98地点の資料を基として, 豪雨と長雨の季節による分布, 月降水量への寄与度, 出現確率, 地域分布などを1950～60年の期間について議論し, さらに, 広域の天候状態, 循環, 風向, 雷雨経路から, 山岳地形, 植生, 聚落状態をその他の地理的特性のような力学的要因との 関係にまで立ら入って検討を加えている。また，T. J. CHANDLER (1965) は，その著“The Climate of London” の降水の章で, Kew 資料により, 統計的取り扱いによる各種降水要素の 克明な解析を行なっている。すなわち，降水量特よび降水時間の日変化から年変化，降水密度 扣よび雨量強度, 日雨量特よび降水継続時間の階級別度数分布の年変化など細かく分析してい る。

最後に, 大雨の直接の研究論分ではないが, H. LANDSBERG (1950) の “Physcal Chimatology”を取り上げなけ扎ばならない。彼はそのなかで，降水日数执よび雨天日数による平均雨量 (降水密度) 和よび雨量階級別度数をとることの必要性を指摘している。また．降水の日変化を 論じ，集中豪雨を例として，雨の降り方にまで注目しなければならないと強調している。 
以上概観したごとく，従来の気候学に扣ける雨に関する研究では，降水量自体をとりあげて いるすのが多く，日数を取り扱っている研究は少ない。わずかに日本では吉野正敏，関口武ら の研究に見られるだけで，大雨の問題となると，地域特性に対する検討を経ずして，直接大雨 の再現期間を問題にしている。それゆ兄, 大雨の気候学的研究は, 現状では極めて不十分であ るといえよう。

また, 治水めるいは利水計画の基礎として対象集水域の気象条件の調査が㥶施されるのが通 例であるが，これらの調査についてる，日本に括ける大雨の気候学的特性を十分考慮に入れた 調査とは言いがたい状態にある。

本研究は，日本に物ける大雨の気候学的特性を明らかにする一方，間接的には防㷋面の技術 に対する具体的改善策の提示を目的として行なったものである。

\section{2 研究計画と方法}

本研究の目標は, 日本に括ける大雨の発生度数の地域分布, その季節変化の状態の詳細を明 らかにし，さらに，その気象的，地理的原因を分離し明らかにすることにある。

(使用資料)

「気象庁月報」: 気象庁発行

「○。県の気候」：各地方気象台発行

「全国気象旬報」: 気象庁発行

「気象要覽」: 気象庁発行

「日本の気候表」その2: 気象庁発行

$\lceil$ Aerological Data of Japan」: 気象庁発行

「印刷天気図」: 気象庁発行

$\lceil 大$ 雨予想資料」: 気象庁発行

\section{2 .1 研究計画}

上記研究目標を達成するために研究計画を次のようにたてる。

a) 雨量階級別大雨日数の地域分布牞よび季節変化の実状を明らかにする。

b）大雨日数の季節变化呿よび年間日数による大雨の地域区分。

c）雨量階級別度数分布型の地域性括よび安定性を明らかにする。

d）大雨日数の地域性扣よび季節変化を気候学的に明らかにする。

1.2 .2 方法

a) 単位要素として日降水量から大雨日数を求め, 大雨日数を主体として用いる。

b）大雨日数は各地点，月毎に日降水量を次の階級区分によって求めた日数である：

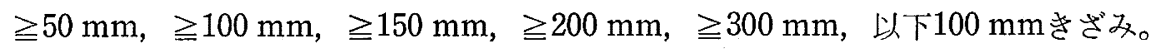

降水量自体を取り上げず，大雨日数を取り扱ったこと，敃よび大雨日数を上記日雨量階級 区分によって求めた理由は次のと招りである。

(1) 水害と日雨量との関係を日本全国について調べると, 気象官署で日降水量 $\geqq 50 \mathrm{~mm}$ の降 雨があった場合には，その周辺の何処かで小水害が発生し，100 mm を越兄ると必ず水害を 発生している。 $\geqq 200 \mathrm{~mm}$ の日降水量の場合には大水害となる。

これらの関係を裏付ける一つの資料として，各雨量階級別の年間大雨日数を都道府県単位 に求める(これを都道府県年間大雨月数とする)。との求め方は都道府県内の気象台, 測候 
所の大雨日数のなかで最大大雨日数をもって該当都道府県の大雨日数とした。水害件数は， 斉藤鍊一編「府県別年別気像災害年表」から水害に該当するものをとり出し，之の出現度数を

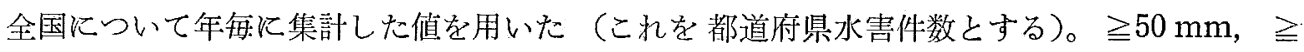
$100 \mathrm{~mm}, \geqq 150 \mathrm{~mm}, \geqq 200 \mathrm{~mm}$ の各階級別の都道府県年間大雨日数全国集計と都道府県年 間水害件数全国集計との関係を 1951 60 年について調べたのが Fig. 1 である。回䡅式と相関 倸数を Table 1 に示したが，資料数がわずが10個であり，相関の良否を㛜密に指摘するわ けにはいかない。しかし $\geqq 100 \mathrm{~mm}$ の場合に最も良い相関関係を示しているといってよいだ ろう。

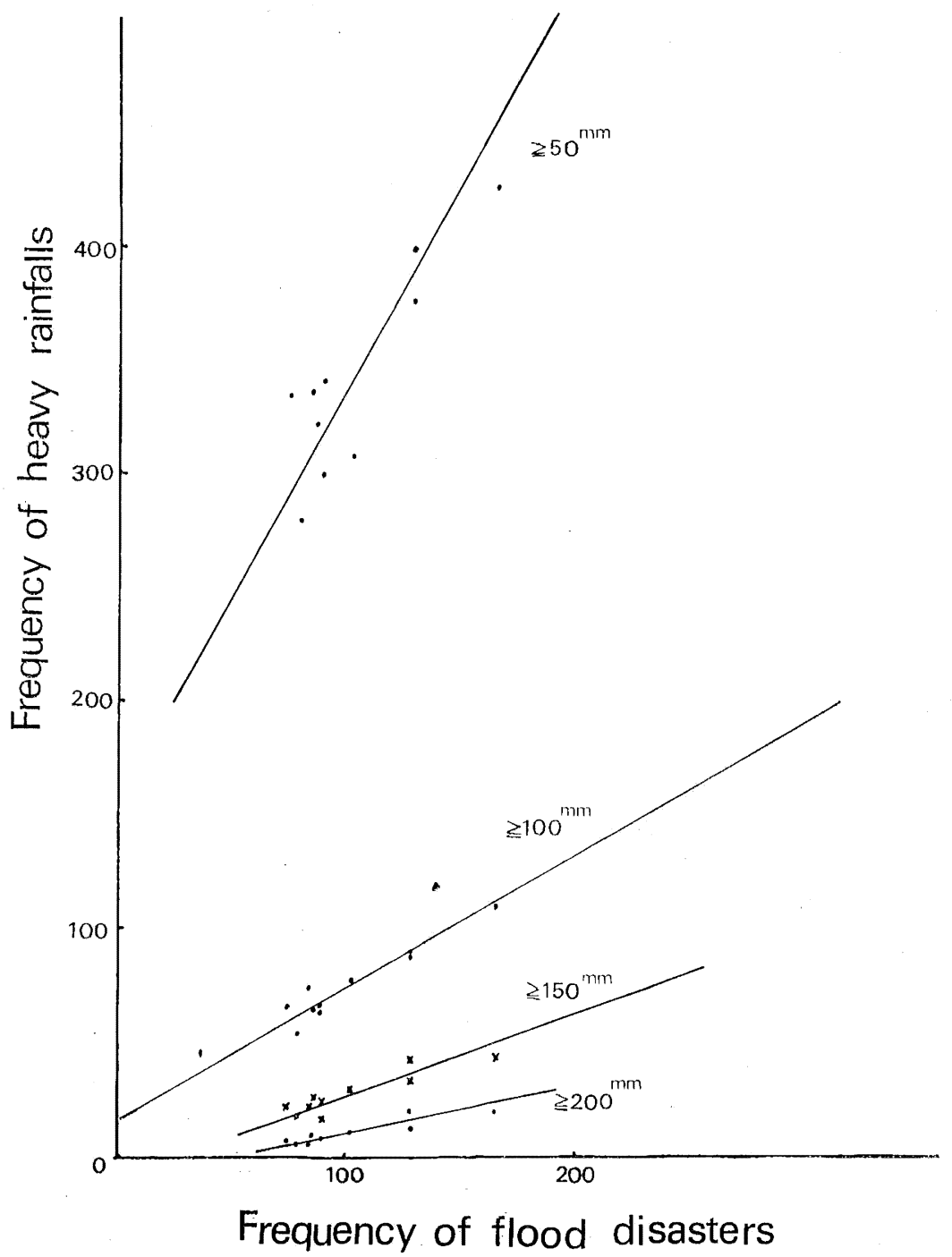

Fig. 1. Relation between annual frequency of heavy rainfalls and that of flood-disasters in Japan (unit is prefecture, 1951-60): 
Table 1. Regression equation and correlation coefficient between annual frequency of specified classes of heavy rainfalls and that of flood disasters in Japan (unit is prefecture, 1951-60).

\begin{tabular}{c|c|c}
\hline Class of heavy rain & Regression Equation & $\begin{array}{c}\text { Correlation } \\
\text { Coefficient }\end{array}$ \\
\hline$\geqq 50 \mathrm{~mm}$ & $\mathrm{D}=0.5480 \mathrm{R}_{50}-80.2352$ & 0.86 \\
$\geqq 100 \mathrm{~mm}$ & $\mathrm{D}=1.7238 \mathrm{R}_{100}-29.6431$ & 0.95 \\
$\geqq 150 \mathrm{~mm}$ & $\mathrm{D}=2.7422 \mathrm{R}_{150}+25.6184$ & 0.91 \\
$\geqq 200 \mathrm{~mm}$ & $\mathrm{D}=4.6920 \mathrm{R}_{200}+50.7880$ & 0.90 \\
\hline
\end{tabular}

$\geqq 100 \mathrm{~mm}$ の大雨日数集計值が水害件数集計值より少ないのは，水害件数には100 mm 以下 の場合でも水害の発生している場合が含まれているからである。

(2) 降水量自体を取り扱った場合には，雨域の広がり特よび雨量強度に関寸る量をる同時に 取り上げなければ，気候学的特性は把握されない。むしろ，大雨日数によって気候学的特性 をまず明らかにし，その結果に基づいて雨域の拡がりや雨量強度などによる細部の気候学的 特性を研究することが，大雨の気候学的特性を明らかにするという目的のためには合理的で 㐫る。

(3) 月降水量, 年降水量は必ずしも大雨日数と一致せず，大雨を問題とするときには階級別 大雨日数を取り扱った方がよい。年降水量と年間大雨日数との間には高い相関関係があって もよいように思われるが，必ずしも高い相関ではない。これは雨の降り方に関係している。 たと兄ば，高田と大島とでは年降水量平年值が注涪等しい約 $3000 \mathrm{~mm}$ である。乙かし，両者

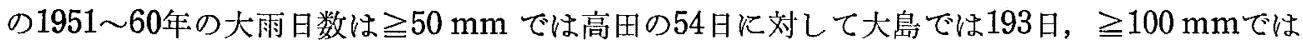
高田の 4 日に対して大島の34日と，はるが大島の大雨日数が多くなっている。また，同一地

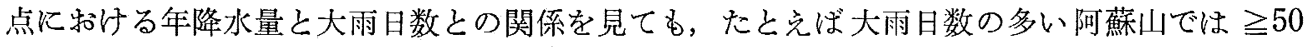
$\mathrm{mm}$ では割合高い相関が得られるが， ミ100 mm の場合には相関が非常に悪くなっている。 この関係は，大雨日数の少ない地点では ミ50 mm の場合でも相関関係が悪くなっている。

(4) 統計的取り扱いは降水量自体よりる日数の方が容易である。

c）使用資料の統計期間は10年間とし，日本全国については1951〜60年の全資料がそろら食象 官署137地点を用い，地域区分の詳細を論じた西日本については資料の関係上 1952〜61年の資 料を用いた。(この期間の資料を用いたのは, ゾンデ資料等の精度が向上されて招り,戦争によ る中断がないこと，他の気候統計值との対比が容易であることなどの理由からであり，10年間 の統計值によったのは,地域特性を明らかにするためには,最低10年を必要とするからである。）

d）研究計画の a ) c ） は統計的手法による。

e）研究計画のd）は, まず大雨の地域性と他の気候要素の地域性との対比から, 従来の気候 区分との関係を検討し，最後に，大雨の地域性ならびに季節変化の要因を動気候学的に明ら かにする。

\section{2 .3 第 1 報との関連}

本論文は，東京教育大学の博士論文として作られたものであるが，論文構成として，「日本に 物ける大雨の気候学的特性（第 1 報)」(Pap. Met. Geophys., 19, 227-308. ) を包含するもので ある。それゆ克，第 1 報と部分的重複は避けられないところも出て来るが，その重複部分は簡 単な記述にして，詳細は第 1 報を参照していただけるように述べてゆくこととする。 
第 1 報から引用する Table 特よび Fig. は Table (I, 1, p. 279) といらょうに, 図表の番号 および掲載頁を付記することとする。

\section{2. 大雨の統計的研究}

\section{1 大雨の地域分布}

10年間の 137 全地点合計の階級別度数の月別分布は Table (I, 1, p. 279) で示し，第 1 報です でに指摘したように階級別度数の分布型は指数関数型となっている。この分布型は各地点につ いてミ0.1 mm の階級までの度数を考慮に入れても同様である。ただし，各地点によって分布曲 線の傾斜飞特徵があると同時に, 統計期間によっても分布曲線の傾斜に変化がある。この分布 型の地域による違いは，大雨の再現期間を求める場合は最も重要な問題となる。

\section{1 .1 年間日数の地域分布}

各雨量階級別年合計值の地域分布を Fig. (I, 2, p. 280) 飞示し，第 1 報で各雨量階級別の分 布の特徵を述べてあるゆ兄, その概要を記述し, 次に日本列島を緯度によって分割した場合の, 緯度変化について述べることとする。

大雨日数の地域分布の特徵は，a）半島や島の東側の方が，その西側より多い。b）瀬戸内 海, 北海道のオホーツク海沿岸, 中部地方内陸部の北部地方に位置する盆地形のところに著し く度数の少ない地域がある。c) 多発域は太平洋沿岸に現われ, 特に顕著な地域は伊豆半島拉 よび紀伊半島の東側と, 九州の内陸部牤よび南東部である。

$\geqq 50 \mathrm{~mm}$ 预よびミ100 mm の大雨日数の地域分布には，一般的傾向として，緯度が高まるほ

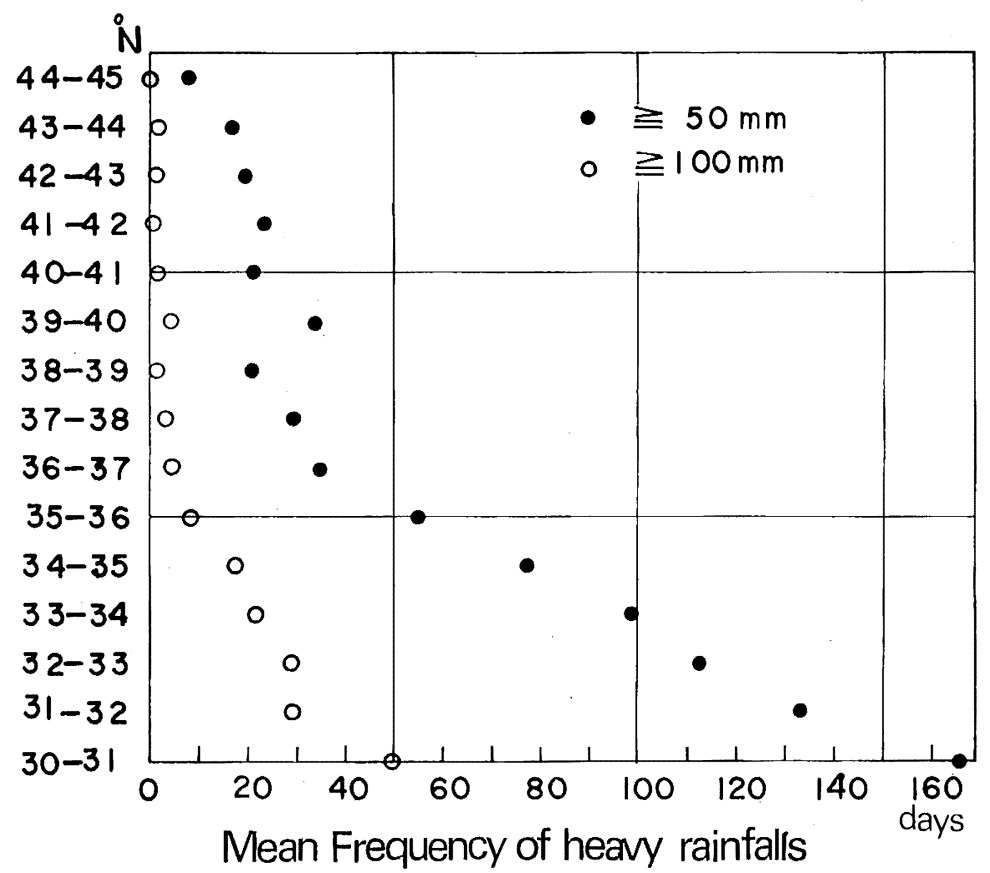

Fig. 2. Latitudinal distribution of the mean frequency of heavy rainfalls in each one degree of latitude in Japan (1951-60). 
ど日数が減少する傾向にある。これをさらに明確にするために, Fig. 2 にミ50 mm 特よびミ100 $\mathrm{mm}$ の大雨日数について, 緯度 $1^{\circ}$ 毎に包含される観測地点の平均日数を求め, 緯度と平均大 雨日数との関係を示した。図から明らかなよらに，ミ50 mm の場合は $37^{\circ} \mathrm{N}$ を境として，それ より高緯度では緯度による変化は緩かであり，それより低緯度では急激な增加を示している。

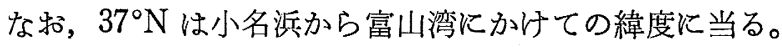

$\geqq 100 \mathrm{~mm}$ の場合は，屈曲点が $\geqq 50 \mathrm{~mm}$ の場合より南下しており， $36^{\circ} \mathrm{N}$ 以南での大雨日数 の増加の仕方が少なくなっている程度で，傾向は ミ50 mm の場合と同様に現われている。な特， $36^{\circ} \mathrm{N}$ はほぼ福井と銚子を結ぶ緯度に当る。

以上のような緯度による平均大雨日数の分布は, 日本列島の複雑な地形分布から生ずる大雨 日数の地域分布を平滑化し，大雨日数の緯度による变化の一般的特徴を示しているものと考兄 られる。な拉, 後章で述べるように, この緯度変化は, 水蒸気量の緯度分布によって説明さ れる。

\section{1 .2 各月の地域分布}

各月の地域分布については，第 1 報の281 284頁に, Fig. (I, 3, 4, p. 282, 283) のミ50 mm お。 よび $100 \mathrm{~mm}$ の 1 ～12月の度数分布を示して，詳細に記述して物いた。本報では後節で述べる

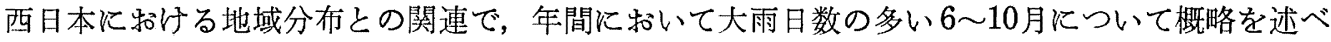
ることとする。

(1) 6 月：年合計值の分布に大体類似するが，特に九州から周防灘沿岸を経て，中国山地の中 央部に延びる度数の多い地域が見られるのと，北海道の北部大半が度数ゼ口，東北地方から関

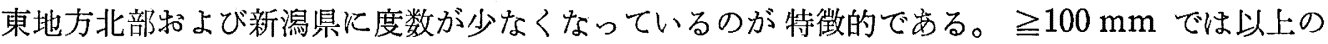
分布の特徵が顕著に現われる。

(2) 7 月: 分布は 6 月とだいぶ違って扣り，度数の多い地域は北海道中央部括よび南部沿岸地 帯，東北地方の日本海側から北陸地方に見られ，九州南部から四国沿岸にかけて相対的に少な い地域が見られる。九州から中国地方に 延びる多発域は 6 月より若干北進している。以上は

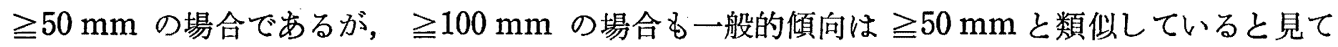
よいが，度数が少ないために明膫でない。東北地方の日本海側に度数の多い地域が現われるの が特徵的である。

(3) 8 月：北海道と東北地方中央西部，九州中央部から東側沿岸部に度数の多い地域がある。

(4) 9 月：9 月の特徴は, 度数の多い地域が日本海側から大平洋側に移ることである。この特 徵の顕著に現われるのは，北海道から東北地方にかけての地域であり，東日本内陸部にも度数 の多い地域が見られる。

(5) 10月：9月の分布特徵がさらに顕著に現われる。北海道から東北, 関東兩地方の太平洋岸 に度数の多い地域が現われ，日本海側は度数の少ない地域となる。 中国地方以西之太平洋岸，それに東北地方の秋田，岩手を連水る地帯に見られる。

2.1 .3 大雨日数多発域の季節変化

第 1 報に括いて，すでに日雨量 $\geqq 50 \mathrm{~mm}$ の大雨日数によって，各月の年間大雨日数総計に対 する百分率を各地点で求め, その分布を Fig. (I, 8, p. 298) に示し, さらに, 日本付近を通る 低気圧の各月の経路を Fig. (I, 8, p. 300) に, 同じく低気圧の発生個数, 通過個数括よび総個

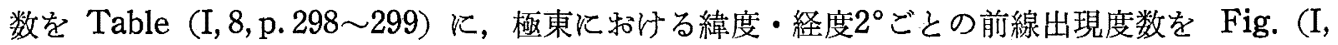


10, a ), b ), p. 301 302) に示して，大雨日数多発域の季節変化をそれらの気像じょう乱出現の 季節変化と結びつけて論じた。その結論だけを要約すると，次のようになる。

大雨日数多発域は明らかに季節変化して特り，その変化は，前線帯や㫫著低気圧，台風など の気象じょら乱の発現度数, 経路の季節変化特よび流入水蒸気量の季節変化とによって説明さ れる。ぬた，関東地方内陸部と中部地方中央部括よび京都盆地の 8 月の多発は雷雨によって説 明される。

\section{1 .4 西日本に叔ける地域分布}

気象官署のみによる大雨日数の地域分布に扣いて, 紀伊半島の東西雨側面あるいは紀伊水道, 豊後水道の東側沿岸と西側沿岸との間に日数に大きい相違があり，半島または島の場合には東 側，水道は西岸地域の方が反対側より多い傾向が見られる。気象官署のみでは分布が粗いので, これらの問題の検討を含めて, 詳細な地域分布の検討を西日本（ただし九州は福岡，大分雨県 のみ）の区内観測所資料によって行なった。「全国気象旬報」から気象官署の場合と同様の手順 で大雨日数を求めた。 統計期間は1952 61年の10か年であるが，資料の都合から 1952年 9 月〜 53年 4 月の 8 か月を欠いたが，大勢を見るのにさしつかえないと考党る。

Fig. 3 に 6 10月の $\geqq 100 \mathrm{~mm}$ の西日本に和忛る大雨日数の地域分布を示した。各月の分布 の特徵は次のと抮りである。

(1) 6 月：周防灘に面した九州沿岸に少発域が方り，対岸山口県の多発域と対称的である。瀬 戸内海地方の少発域は同地方中心部から東にある。四国および紀伊半島は太平洋沿岸沿いに多 発地帯があり，兵庫県六甲山系から京都北西部にかけて割合多い地帯，鈴鹿山脈東側から岐阜 県北部山間地方にかけて細長い多発地帯が現われている。

(2) 7 月：6月より複雑な分布を示し，前線 帯の北上に伴って山陰地方から福井県にかけての 日本海に面した地方でも $\geqq 100 \mathrm{~mm}$ の日数が現われ，瀬戸内海地方の 0 日数の地域は部分とな り，同地方中心部より東方に現われる。太平洋沿岸の多発地帯では，四国の日数は 6 月とほぼ 同程度であるが，紀伊半島では少なくなっている。

(3) 8 月：多発域は四国山地太平洋側斜面，紀伊山地東側斜面と，岐阜県雨白山地南部から鈴 鹿山脈にかけての地帯に見られ，兵庫県六甲山地と島根県の中国山地西方にも部分的に割合多 い地城が部分的に見られる。瀬戸内海地方を中心とした 0 日数の地域は周防灘の方が広がる。

(4) 9 月: 多発域は四国山地, 紀伊山地特よび鈴鹿山脈から雨白山地西南部にかけの細長い地 帯に見られ，瀬戸内海地方の 0 日数地域の大半は北岸中国地方沿岸に限られ，大雨日数の多い 周防灘沿岸でも少なくなっている。

(5) 10月：9月までの太平洋沿岸沿いの多発地帯では紀伊山地東側を除いて全域にわたって急 減している。

[西日本に招ける大雨日数地域分布の特徵]

区内钼測所資料に上る西日本の大雨日数の地域分布を見ると, 以上のように, 気象官署資料 のみでは見出し得ないいくつかの特徴が現われている。それらは次のように要約される。

(1) 瀬戸内海地方の 0 日数域を含む少発域は6，7月には同地方中心部より東方に現われ，9月に は反対に西方に現われる。

(2) 周防灘に面した九州側沿岸では中国側沿岸部と対称的に少発域となる。

(3) 兵庫県六甲山地から京都府丹波山地にか子て割合多い地帯が見られる。 


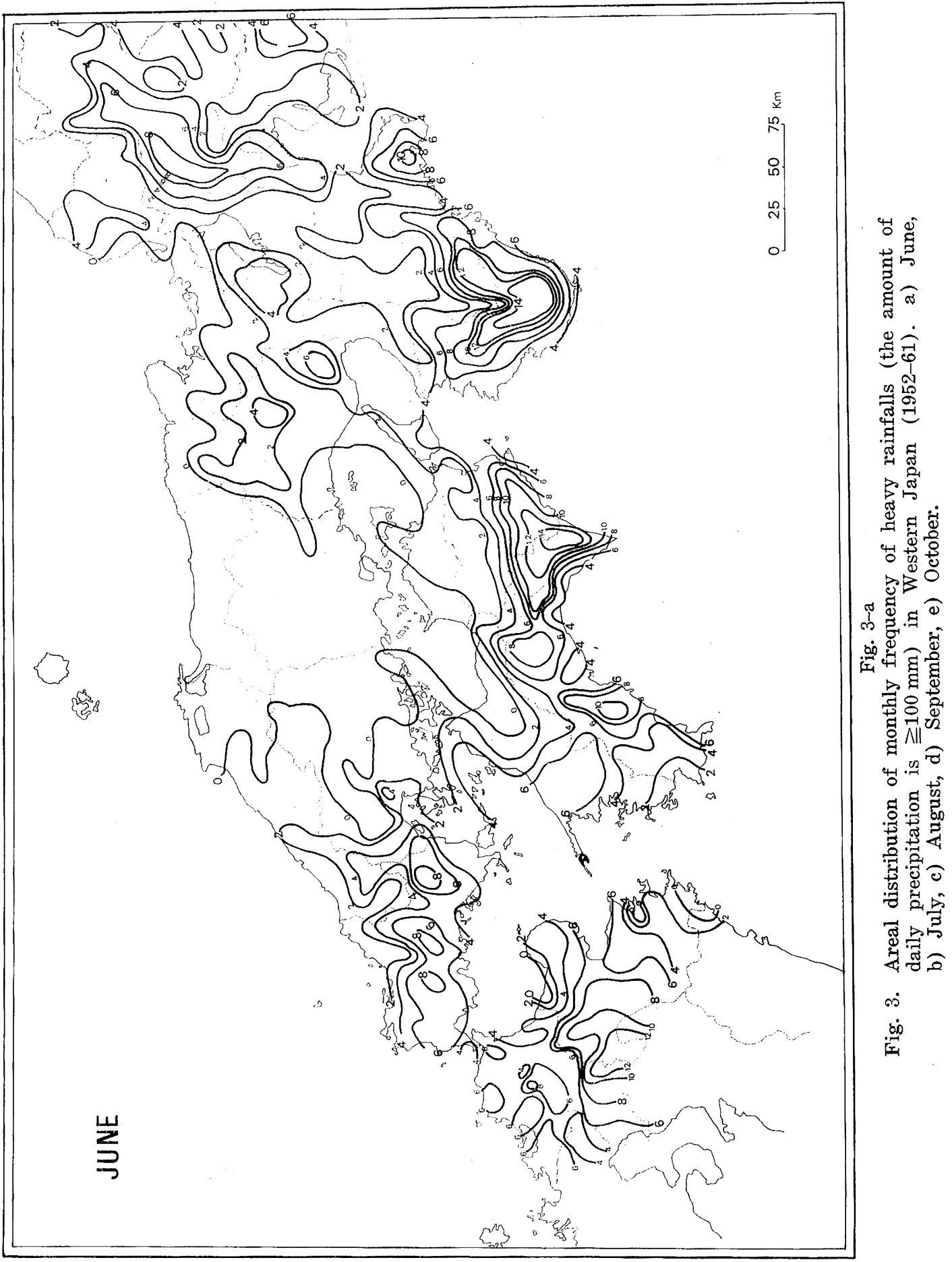




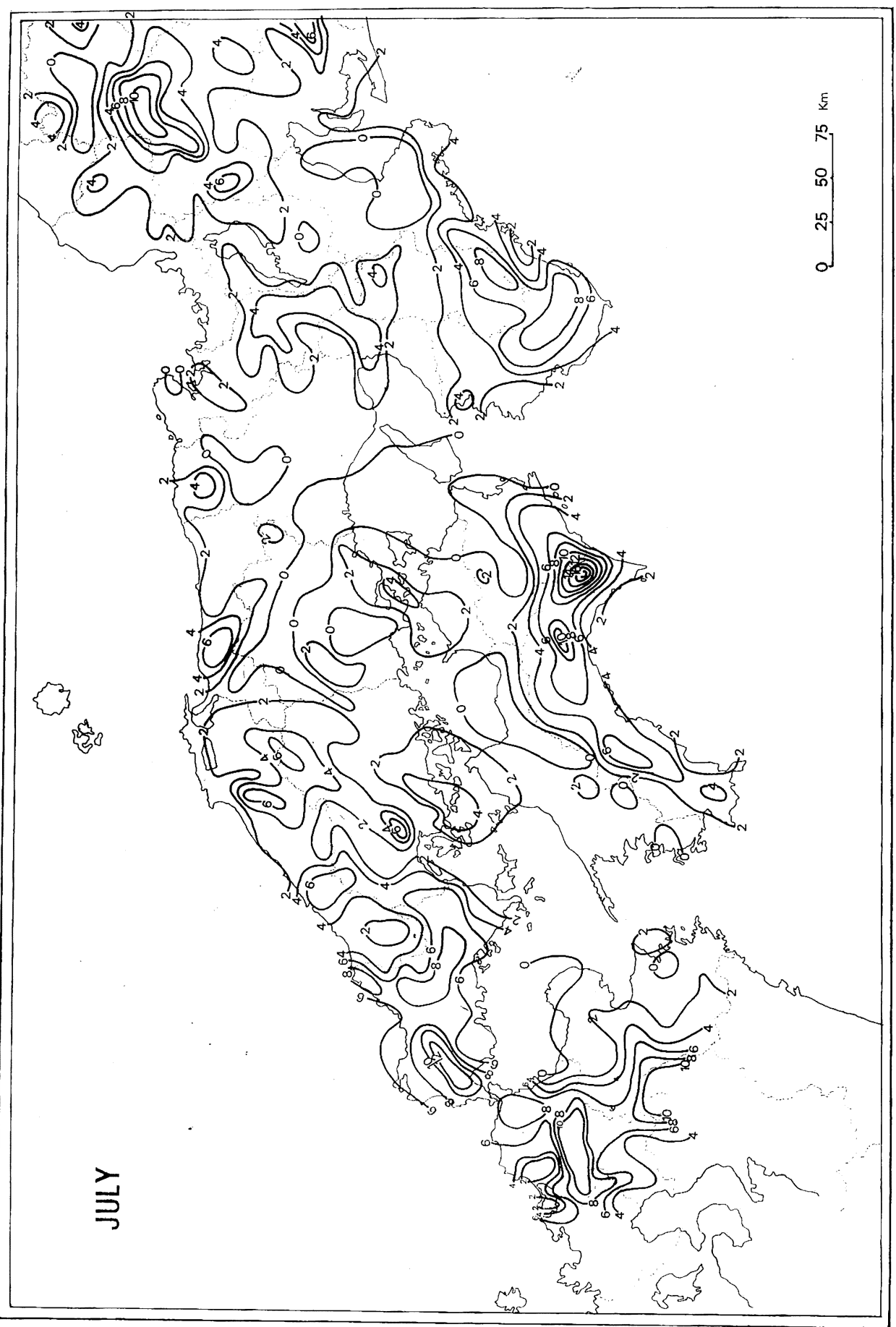

离 


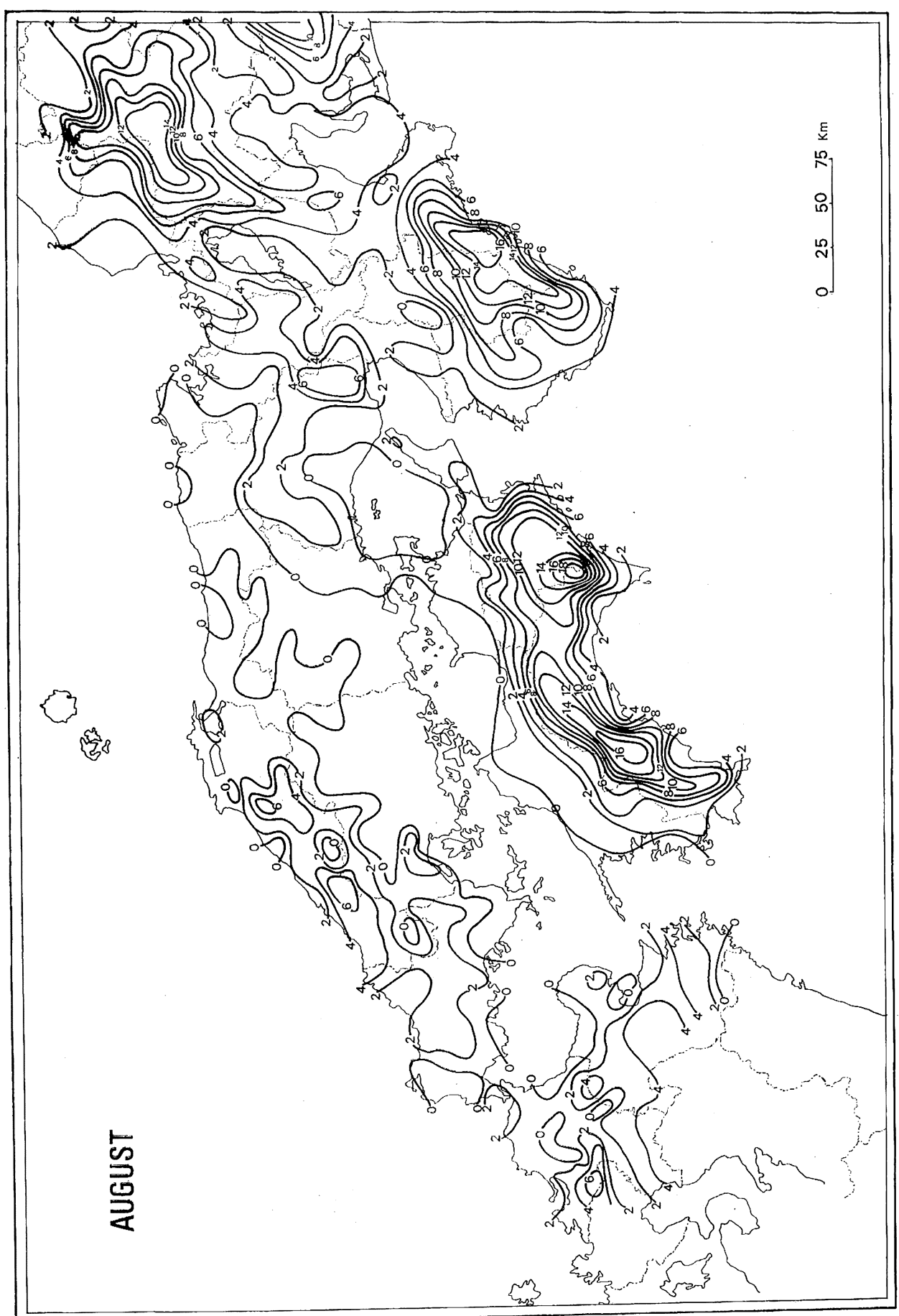

0
0
0
0 


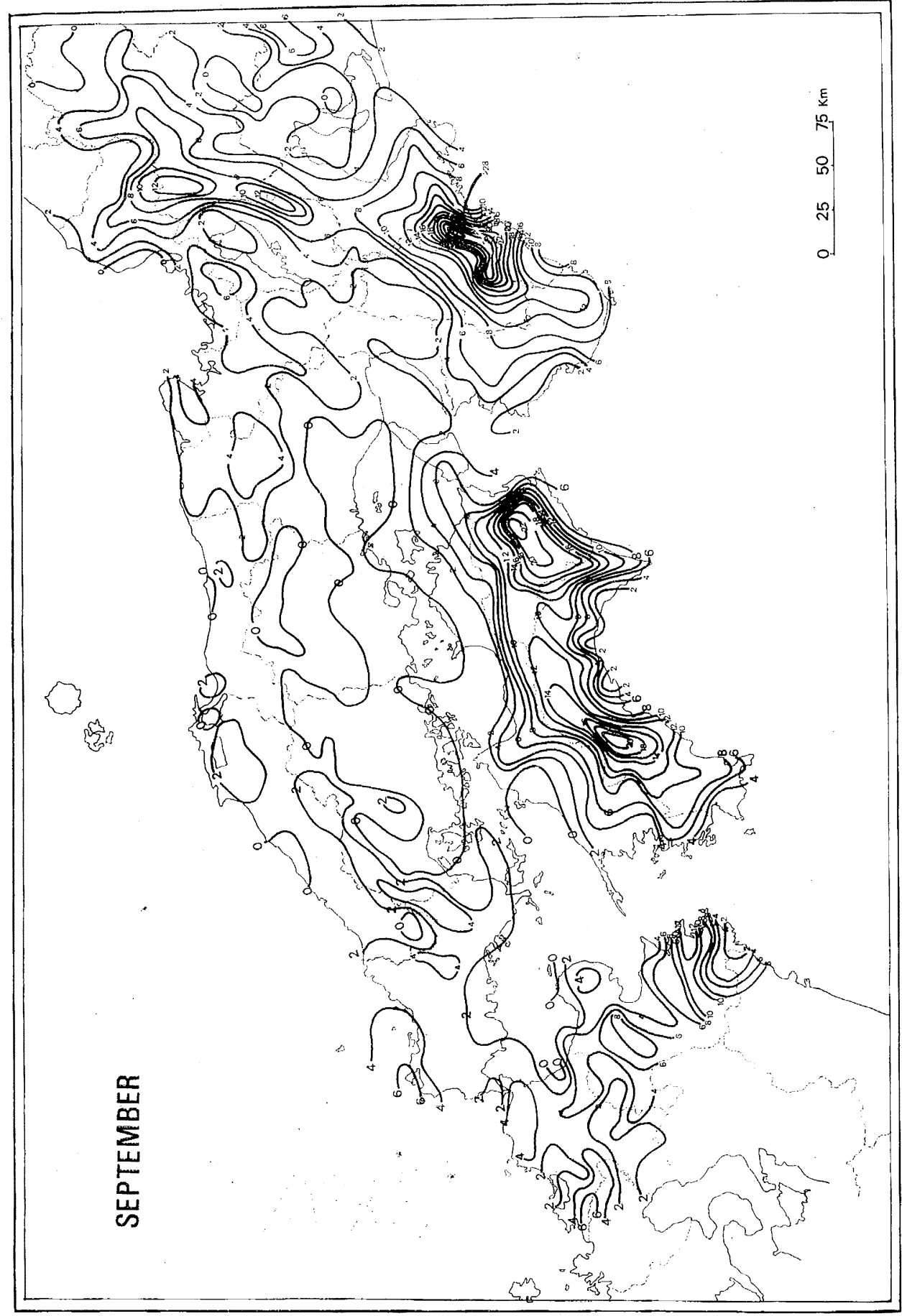

iे 


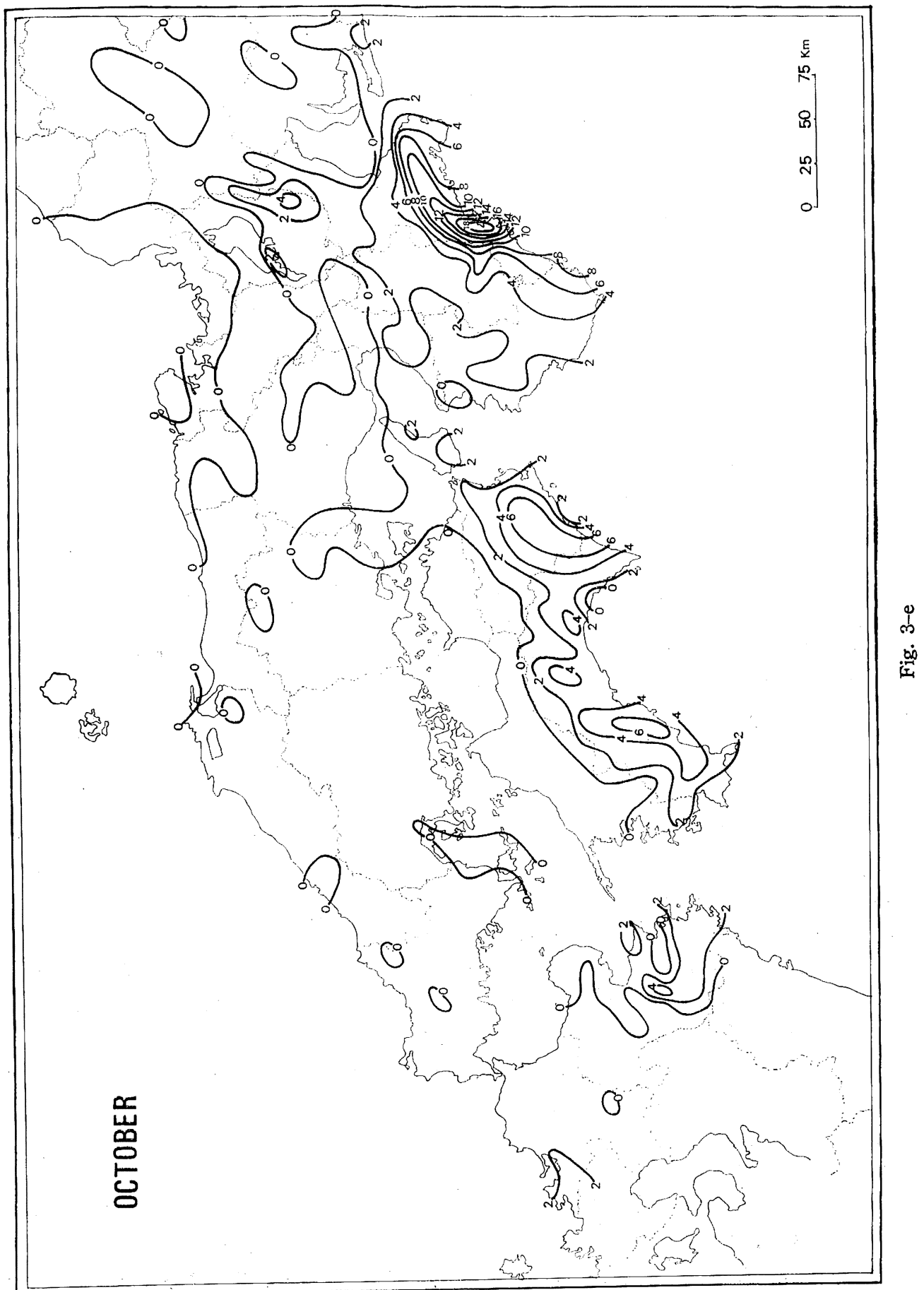




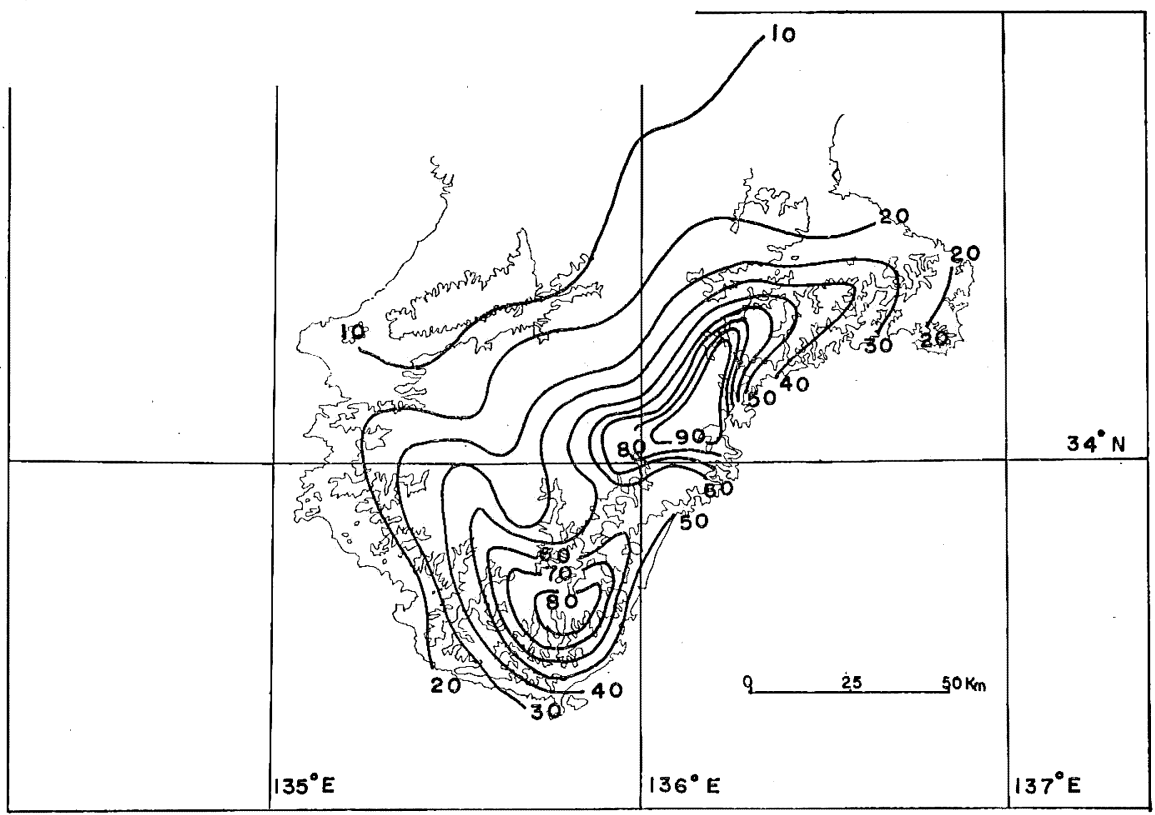

Fig. 4. Areal distribution of the total sum of the frequency of heavy rainfalls (the amount of daily precipitation is $\geqq 100 \mathrm{~mm}$ ) in the Kii Peninsula (1952-61).

(4) 多発域は, 四国山地, 紀伊山地, 鈴鹿山脈, 両白山地と, 山地飞密接に関係して現われ, 梅雨期の 6,7 月と台風期の 9 月とでは多発域中心域の位置に微妙な変化がある。すなわら, 気 象官署資料のみの分布に怙いて指摘した半島東側が西側より大雨日数が多いという特徴は, 6〜7月にはいちじるしくないが，9月には顕著である。紀伊半島の年間総日数分布図を Fig. 4 に示したが，この特徵が明膫に現われている。

(5) 山地が割合海に迫っている地方の多発域中心軸の海岸からの距離は注ぼ一定で, $15 \sim 30 \mathrm{Km}$ の範囲に入っている。

以上のような分布特徵の気候学的検討の細部は後章に譲るが, 次のように理解することがで きる。日本に和ける大雨の季節は梅雨期と台風期であるが，梅雨期の大雨は前線が日本列島上 あるいはとの沿岸近くにあって，低気圧が前線上を東進することによってもたらされることが 多い。そして，湿潤暖気流は主として西南西～南の気流となって流入する。これに対して台風 期は台風や顕著低気圧の北上ないし東進によってもたらされ，それらの進行前面に湿潤暖気流 が東南東〜南の強風となって流入する。このような湿潤暖気流の流入経路の相違が梅雨期と台 風期の分布を微妙に変兄ているといえる。

\section{2 大雨日数の地域的特性}

\section{2 .1 大雨日数による地域区分（日本全国）}

以上は大雨日数が如何に分布しているか，その事実を述べたのであるが，大雨日数の季節変 化执よび年間総日数によって 4 個の主型と，それらの中間型に分けられる (Fig. 5 参照)。ま ず，気象官署のみによって日本全国について区分し，西日本を例として，さらにその細分を行 ならこととする。

I . 年間総数が少なく, 暖候期にしか現われない。（太平洋沿岸を除いた北海道, 青森湾沿岸, 


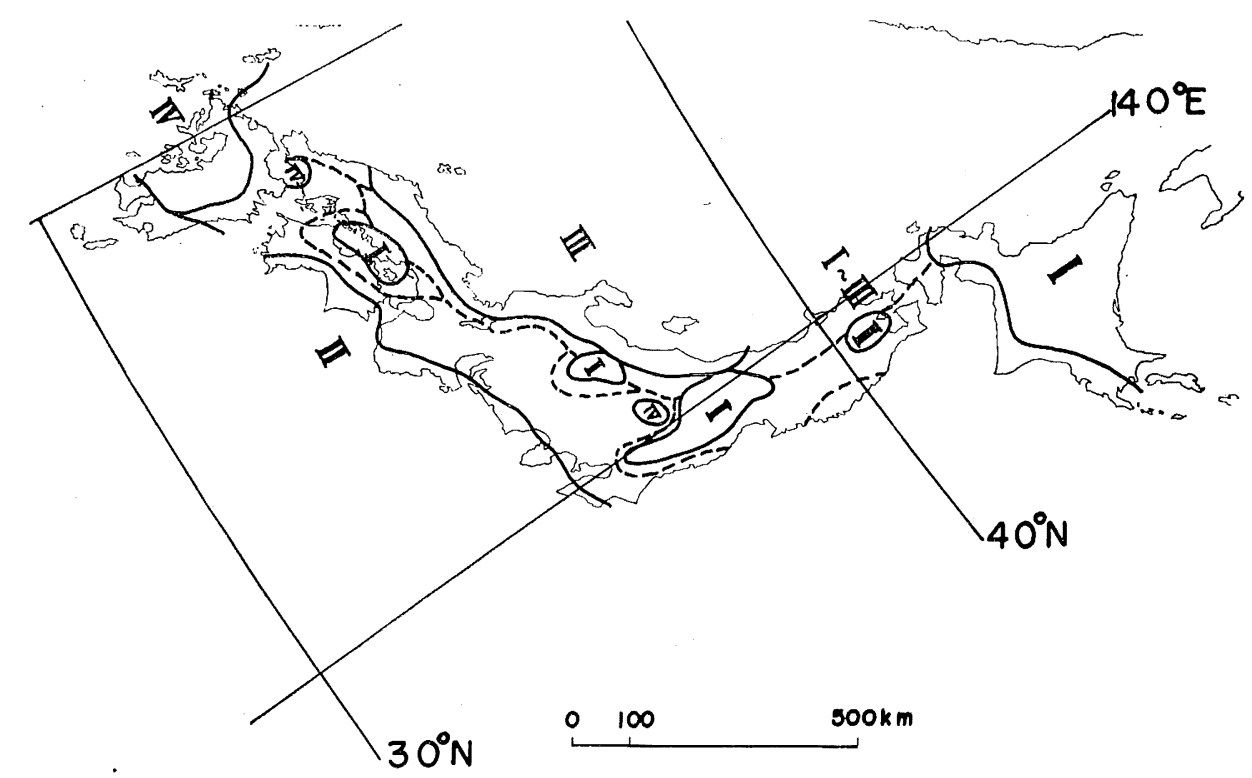

Fig. 5. Synthetic classification of regions for heavy rainfalls in Japan.

I: low frequency through the whole year.

II: high frequency through the whole year.

III: high frequency in winter.

IV: high frequency in the warm season.

山形県から福島県太平洋寄り内陸部, 長野県北部盆地, 瀬戸内海中央部)

II. 年間総数が多く, 年間を通じて現われる。(太平洋沿岸)

III. 年間の日数極大月が12月に現われるか，冬季に日数が多い。ただしミ100 mm の大雨はほ とんど暖候期にしか現われない。(日本海沿岸)

IV. 年間総数が割合多いが, 暖候期にしか現われない。(九州内陸部や関東地方の北部山岳地帯) 中間型は上記 4 主型の特徴の中間的なるので，それらの中，I〜IIの中間型，I〜IIIの中間 型が明らかに見られる。以下各主型特よび中間型について記述する。

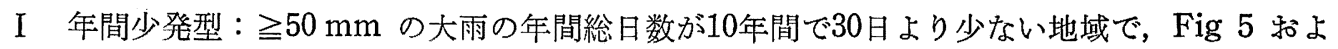
び Table 2 に示すように, 北海道の太平洋岸を除いた地域, 福島県内陸部, 長野県北部特よび 瀬戸内海沿岸地域に見られる。その他，青森湾沿岸や日本海沿岸でも新潟のように局地的少発 域が見られるが，新潟は佐渡島の影響によって，じょう乱扣よび水蒸気の同地方への流入が妨 げられるために局地的に大雨の出現数が少なくなっているもので, 新潟は而の冬季多発域の分 類に入れる。(地域の細分化の場合には分離が必要)。

この型の特徵は, 特に北海道のオホーツク海沿岸, 長野県北部に現われる。

II 年間多発型： $\geqq 50 \mathrm{~mm}$ の大雨の年間総日数が 10 年間で 80 日以上で, 年間を通じて大雨の発 生が見られる。Fig. 5 特よびTable 3 に示すように, 房総半島以西の太平洋沿岸がこの地域に 当る。同じ多発域の中にも, 房総半島のように90日以下のところから, 尾鴝のように238日という 多発域まで含まれる。東北地力太平洋岸は年間総日数は少ないが. 多発型の特徽を持っている。

III 冬季多発型：冬季季節風の卓越する時期に大雨が多発する地域である。ただし， ミ100 mm の大雨となると，暖候期に発生するものが汪とんどで，Table 4 に示すように，わずかに豪雪 


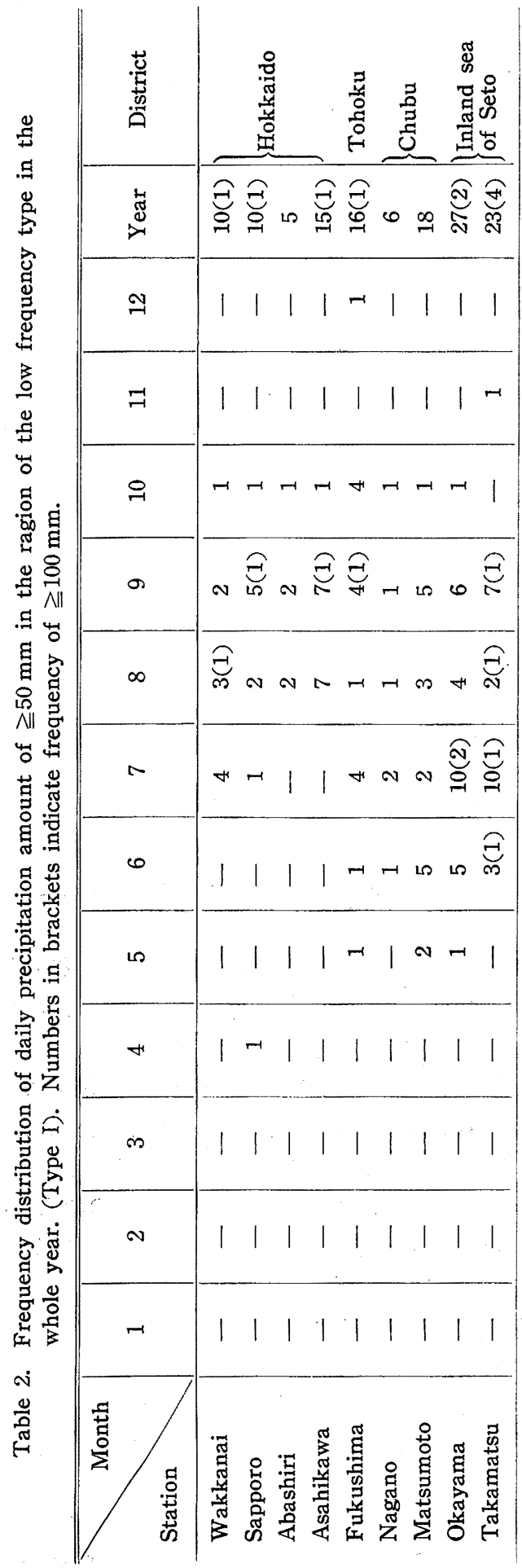

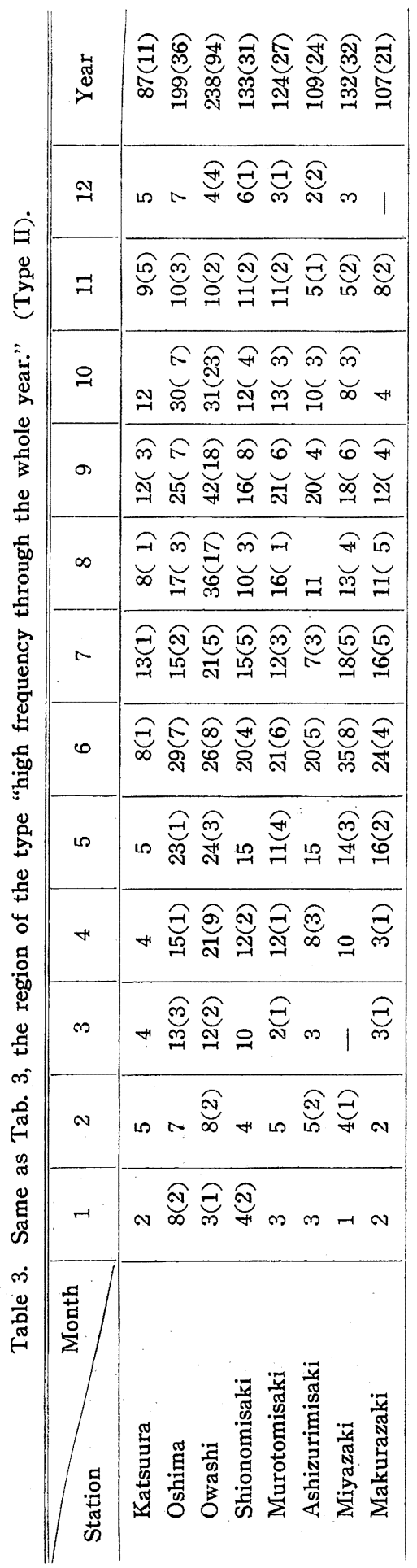



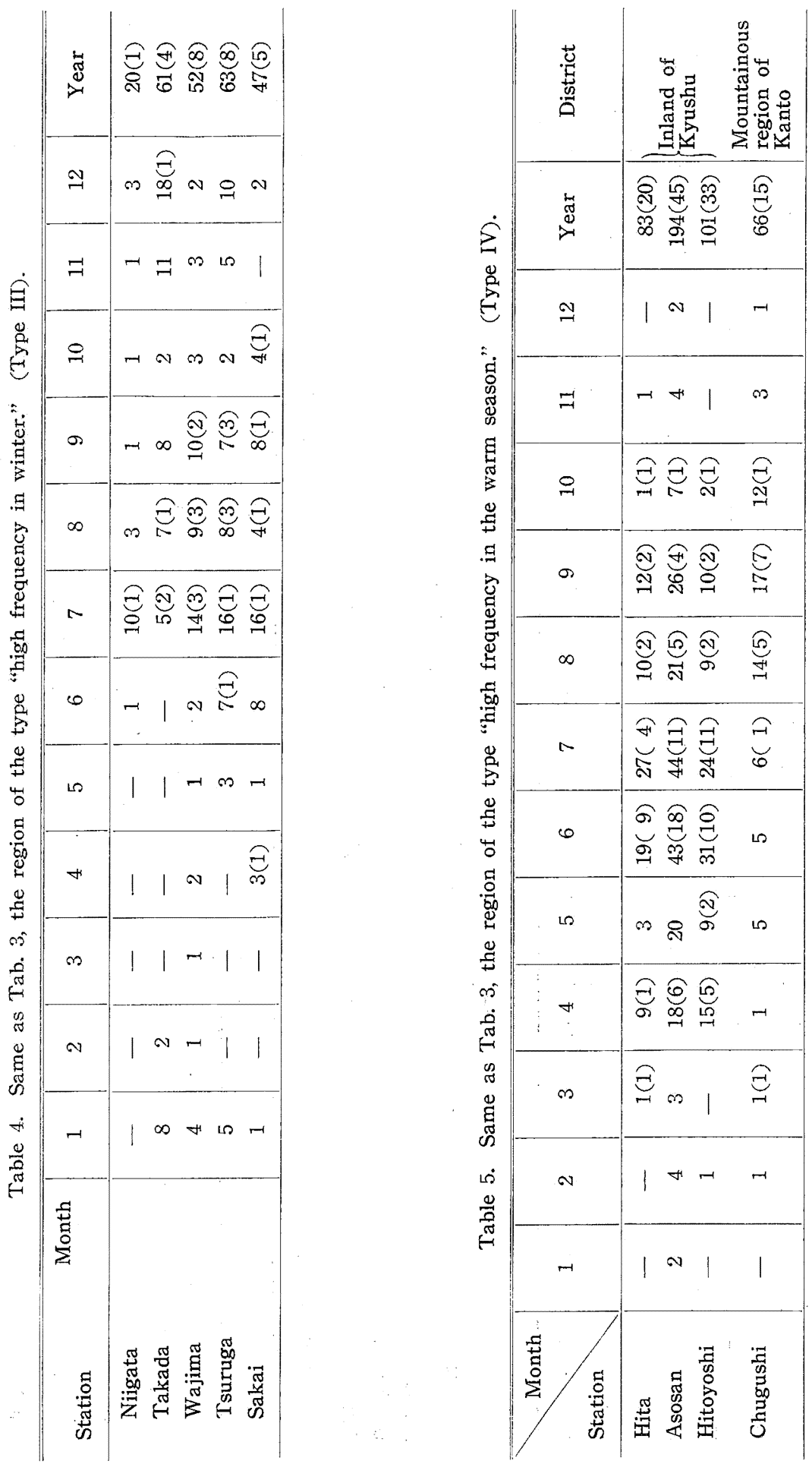


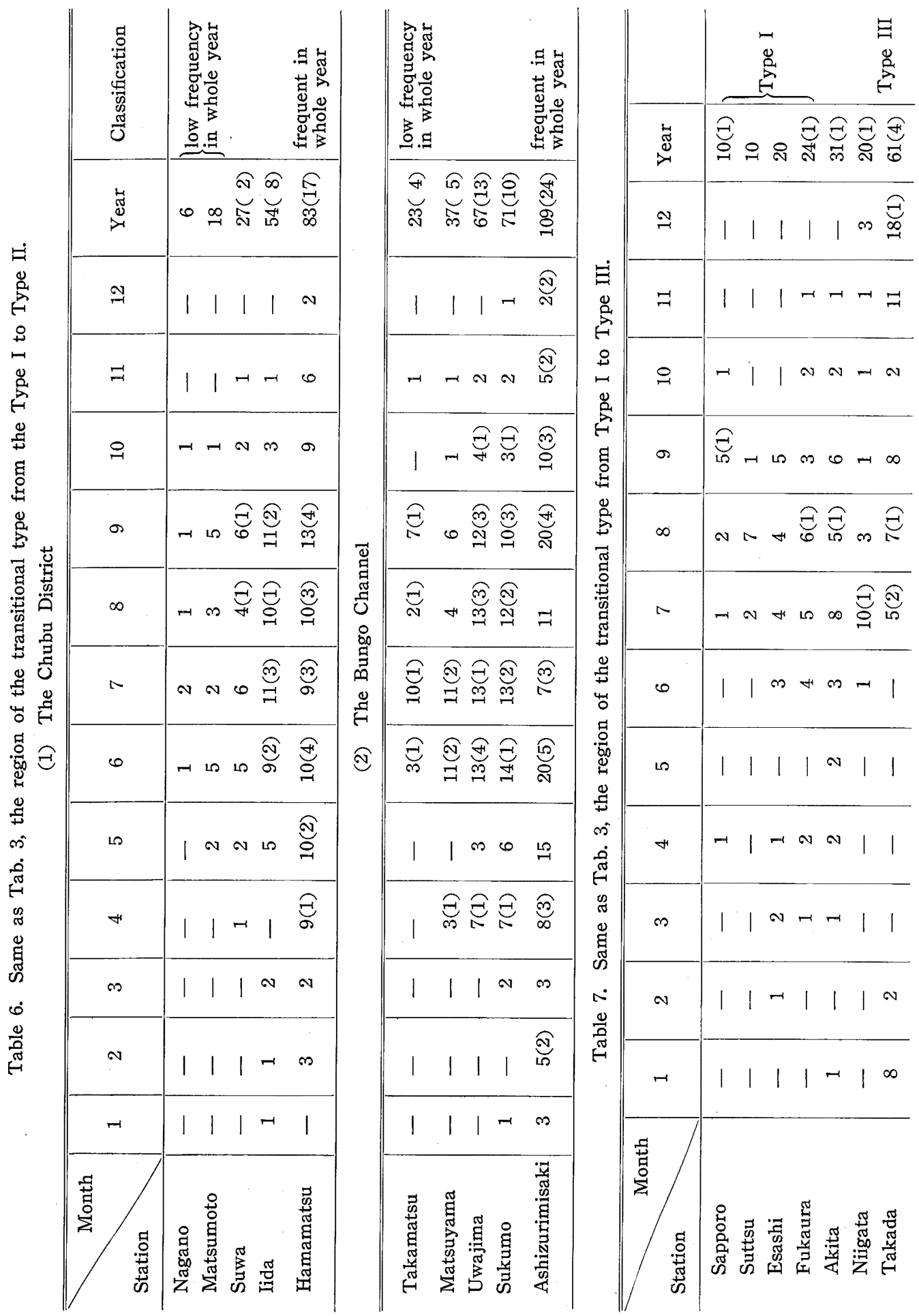


地帯である高田に 1 日見られるだけである。年間に拈ける最多発月は 7〜9月のいずれかの月に なる地点が多いが，高田や敦賀は12月の多発が目立っている。冬季多発型の地域内でも，新潟 のように日数の少ない地域と, 高田や敦賀のように多発する地域とがあり, 地域の細分化が可 能である。

IV 暖候期多発型 : 10 年間の $\geqq 50 \mathrm{~mm}$ の年間総日数が 80 日以上で，乙かも6 9月の日数の年間 総日数に対する割合が $80 \%$ 以上，6 9月の最多特よび次多月の日数の年間総日数に対する割合 が 40\% 以上の地点によって暖候期多発型とした。ただし，中宮祠は年間総日数が66日で，80日 よりはるかに少ないが，同緯度の平均日数 35 日の約 2 倍の出現率を示しているので，特にこの 型に入れてある。

この型に入る地域は Fig. 5 物よび Table 6 に示すように, 九州内陸部から東支那海沿岸に かけての地域と, 関東地方山岳部である。な特, 豊後水道に面した防府がこの型の基準に合致 していることを付け加えて拈く。

$\mathrm{V}$ 中間型：各主型間に中間型が存在するのであるが，細部にわたっては区内観測所の資料で 解析した結果を必要とする。それゆ兄, ここでは主型間の転移地域として, 明らかに中間型が 認められる地域について述べる。な拉，区内観測資料を基とした転移層の細分は次節で論ずる こととする。

(i) 年間少発型と年間多発型の中間型 : 少発型と多発型との中間型は, 両型の中間地帯に存 在する。その典型は中部地方の長野から太平洋岸の浜松までの間, 瀬戸内海中央部から豊後 水道に面した四国西岸に見られる。四国東岸の紀伊水道に面した地域では, 気象官署資料の みでは中間型の存在は不明で, 徳島では太平洋岸の年間多発型類似の型となる。中部地方の 場合と四国沿岸の場合とを Table 6 (1),(2)に示した。

(ii) 年間少発型と冬季多発型の中間型：この型は Table 7 に示すように, 北海道南部の日本 海沿岸から東北地方の日本海沿岸に見られる。北海道の渡島半島北部ではまだ少発域である が, 南部の江差では $250 \mathrm{~mm}$ の年間総日数が 20 日以上となり, 東北地方の日本海沿岸を南下 するにつれて冬季多発型に近づく。

\section{2 .2 大雨日数による地域区分（西日本）}

前節では気象官署のみによる全国の地域区分を行なったのであるが，各主型間の中間型特よ び主型の細部の分布については観測地点網があまりにも粗なために詳細な立論をさしひかえな ければならなかった。本節では区内観測所資料を基にして，西日本を対象にこの問題について 検討を加壳ることとする。

(1) 4 主型と中間型細分による地域区分。

前節の区分に中間型として次のような細分型を付加する。

I とII の中間型（年間少発型から年間多発型または暖候期多発型への中間型）

$\mathrm{I}^{1}: \geqq 50 \mathrm{~mm}$ の年間総日数が $30 \sim 39$ 日

$\mathrm{I}^{2}: \geqq 50 \mathrm{~mm}$ 同 上 $40 \sim 49$ 日

$\mathrm{I}^{3}: \geqq 50 \mathrm{~mm} \quad$ 同 上 $50 \sim 79$ 日

IVを除く他の型との組み合わせ型（冬季多発型と年間少発型, 年間多発型およびその各中間型 との組み合わせ型)

$\mathrm{I}^{1}-\mathrm{III}: \geqq 50 \mathrm{~mm}$ の年間総日数が30〜39日で，冬季にも日数が多い。 


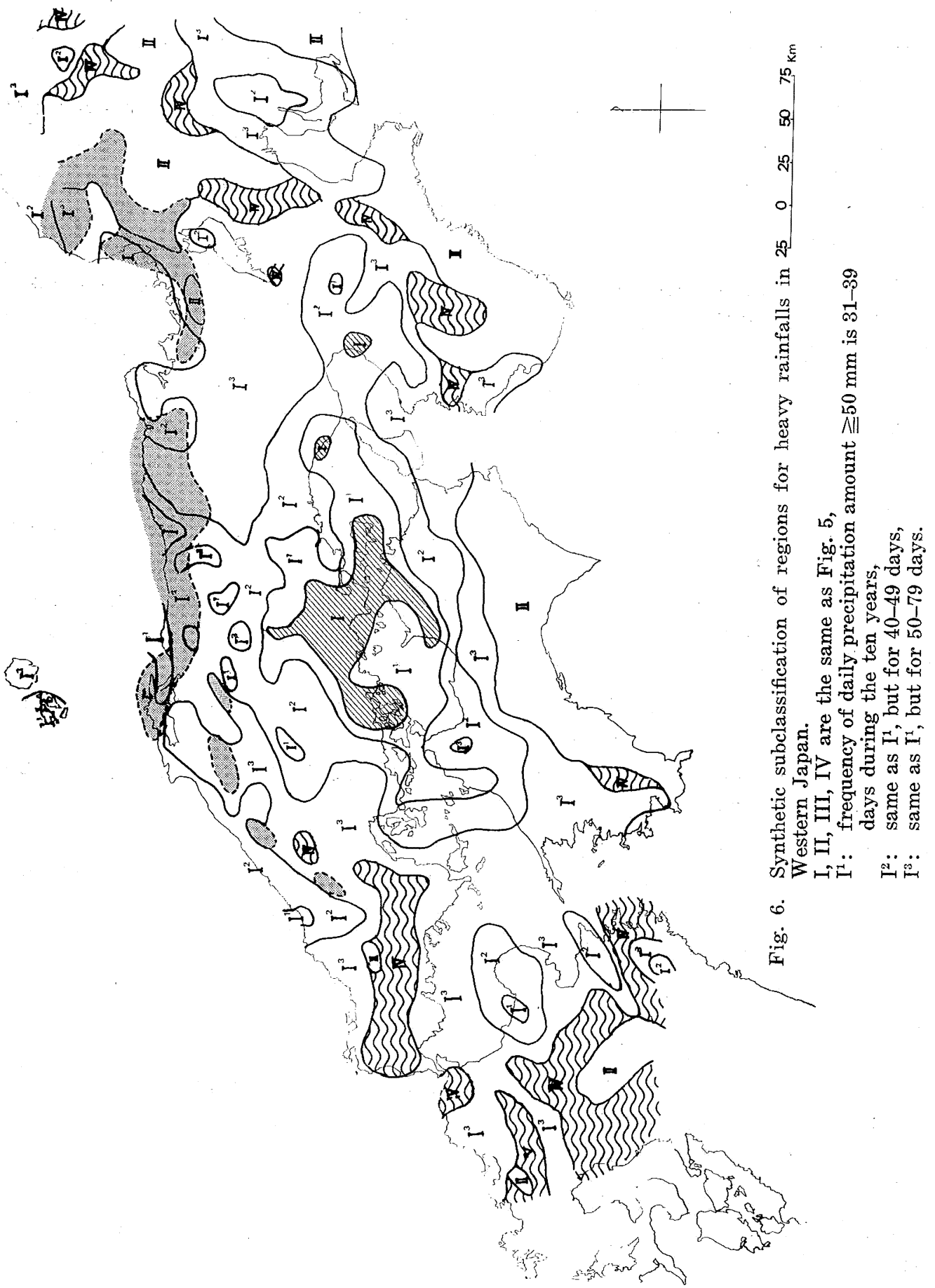




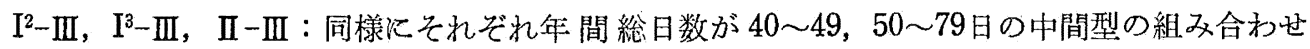
と，年間多発型との組み合わせが作られる。〔I（年間少発型）との組み合わせる考学られる が，西日本ではなかったので省略した。]

以上のような中間型の細分特よび組み合わせによって西日本について地域区分したのが Fig. 6 である。分布が複雑であり，分布の詳細を述べるよりは図を見て判断していただいた方がよ いので, 特徵的なるのだけを以下にあげて特く。

(1) 年間少発型 (I) は瀬户内海地方中心部にあるが, 四国側より中国側の面積が厇く, 特に岡 山県側は内陸部に広く入り込んでいる。兵庫県の高砂市付近にも局部的に見られる。

(2) 年間多発域 (II) は四国, 紀伊半島の大平洋側に見られるが, 雨地方とも東側の方が北方ま で大り込んでいる。また，鈴鹿山脈東側から岐阜県执よび福井県の山岳地带にかけて広汎に現 われている。

(3) 冬季多発型 (III) は日本海側地方に現われているが，島根紧では島根半島以外は山間部に現 われている。また, 福井県では冬季多発型の地域に年間多発型の地域が多く含まれているのも 特徽の一つである。

(4) 暖候期多発型 (IV) は九州と山口県に多く, 四国と紀伊半島では山脈の稜線付近に存在し, 岐皁県東部山萎地带についても同様の傾向がある。

(2)，最多発月扣上び梅雨期と台風期との大雨日数の比較に上る地域区分。

前項までの地域区分飞，さらに季節変化を細分して，梅雨期 $(6,7$ 月) と台風期 $(9,10$ 月) と でどららが多発するか，梅雨期でも6月と7月とではどちらが多いか，さらに，これらの組み 合わせに 4 月と 5 月の対比を加えるなどによって，地域区分を細分化することが可能である。 これらの中，われわれは年間最多発月による地域区分を気象官署のみによって全国について行 ない (Fig. 7), 梅雨期と台風期の大雨日数の違いと, 梅雨期の 6, 7月のどららに日数が多いか

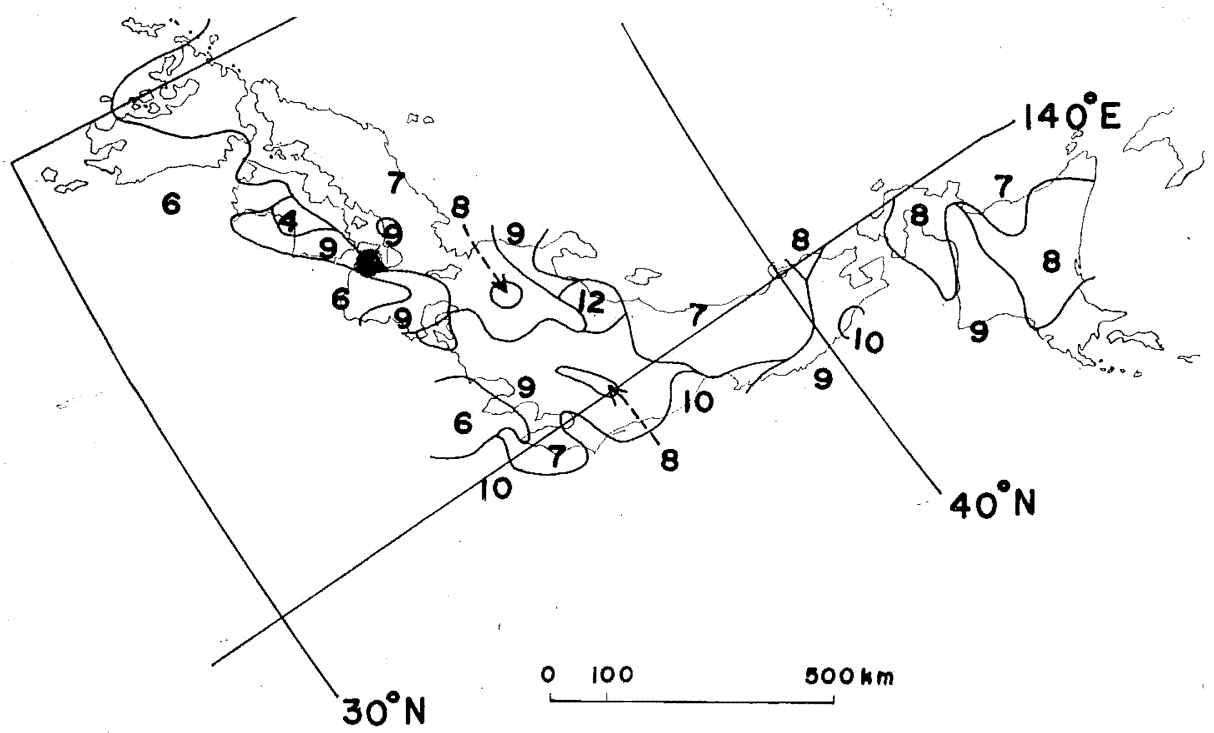

Fig. 7. Classification of region by the maximum frequency month.

とを組み合わせた区分は区内観測所資料により西日本について行なった（Fig. 8)。 


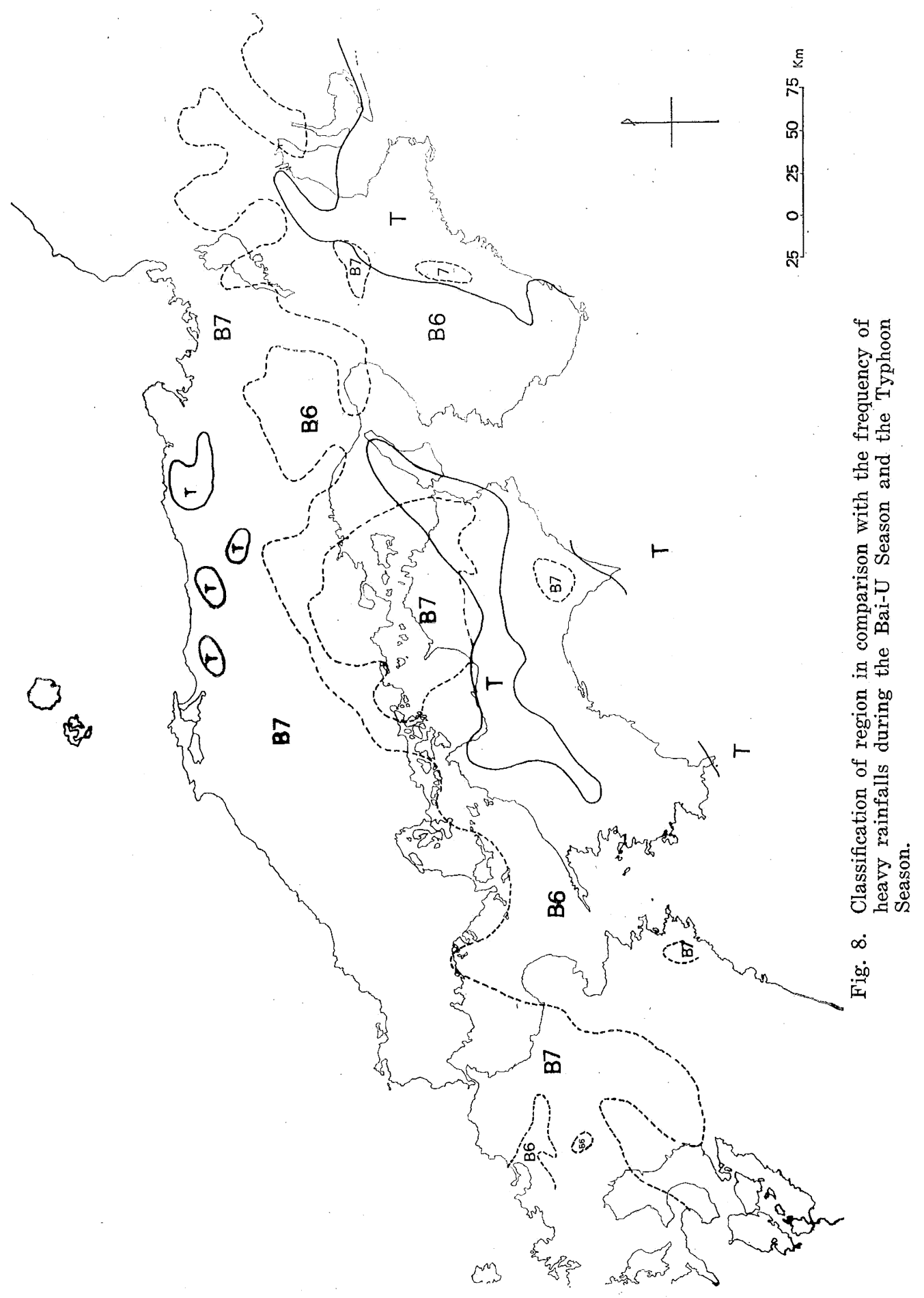


Fig. 7 を見れば明らかなよらに，分布は複雑であり，年間最多発月だけを使用した場合には， 10年間の資料では偶然も作用する叔それがあり，単独使用は避けなげればならないと考觉る。

Fig. 8 は割合まとまって, 意味のある分布をしている。Fig. 7 の分布からる推定されるよ らに, 西日本の大部分は梅雨期の方の大雨日数が多くなっているが，その中で，台風期に多い 地域は次のようである。

(1) 四国の太平洋に突出している足摺岬や室戸岬付近と四国山地から淡路島西部。

(2) 紀伊半島の紀伊山地の東側。

(3) 山陰地方の鳥取県と兵庫県に部分的。

さらに, 梅雨期に大雨日数の多い地域内で 6 月の方が 7 月よりも多い地域は, 九州では大分 県の脊梁山脈東側特よび熊本県南部から南方, 四国では香川県を除く大半, 中国地方では広島 県東部から岡山県内部を経て兵庫県南部までの細長い地帯, 丹波山地の南側, 紀伊半島から琵 琶湖南部执よび濃尾平野と東海地方の南部となって括り，第 1 報で気象官署資料を基にして指 摘した 6 月から 7 月にかケての大雨多発域の北上傾向はここでも明らかに示される。その中で,

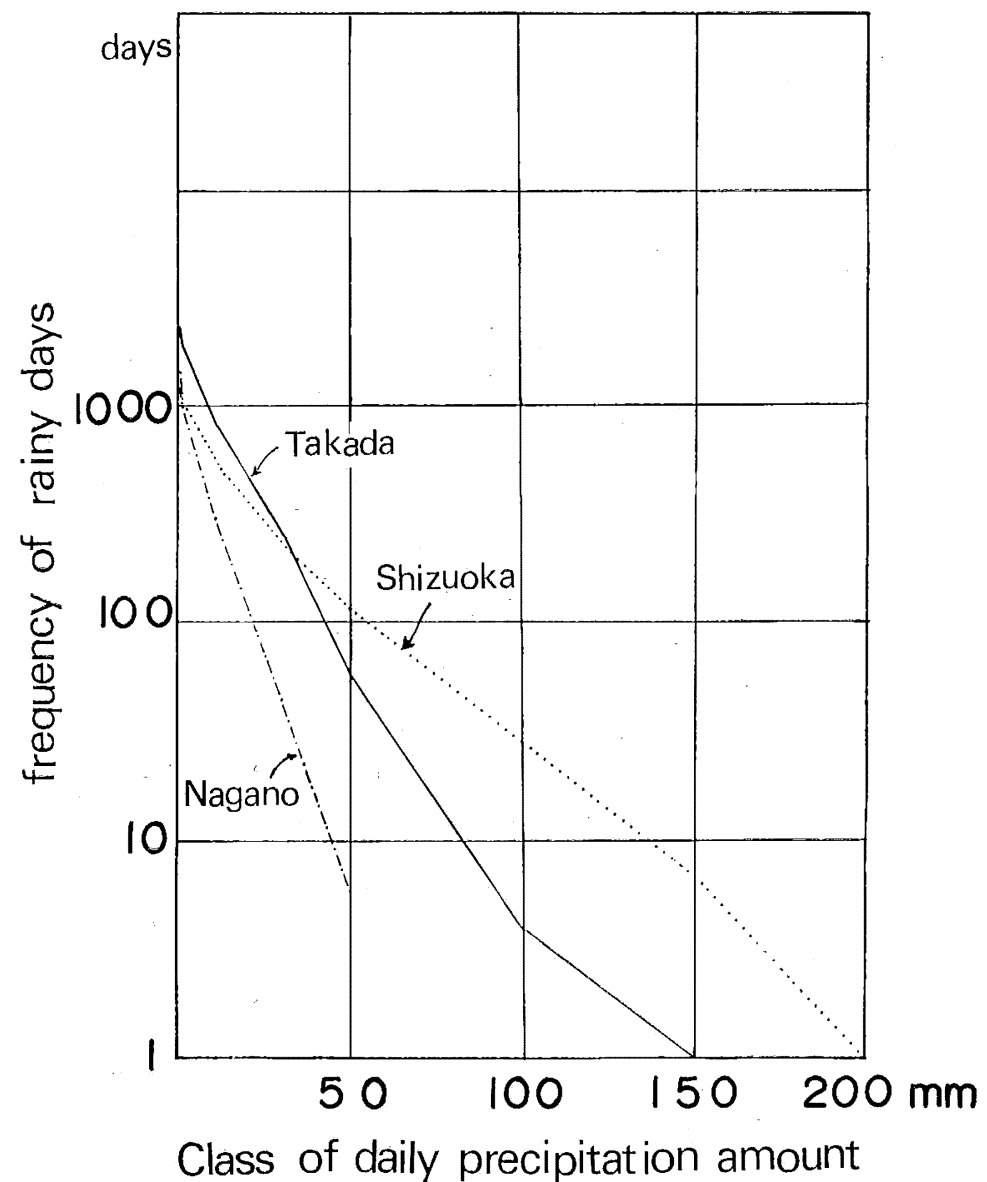

Fig. 9. Examples of the frequency distribution of classified daily precipitation amount. 
室戸岬北方の四国山地南端付近と紀伊山地の大台ケ原付近に部分的に 7 月に多い地域があるこ とと，埛山県北部に細長い 6 月に多い地域がある理由については，湿潤暖気流の流入の海陸分 布抽よび地形による影響によって発生しているすのと思われるが，明快な説明は困難である。

(3) 地域区分に和ける問題点。

以上はわれわれの今回行なった地域区分であるが，まだ次のような問題点が残されている。

(1) 次節で述べるように，10年の統計期間では，まだ偶然が作用する可能性が十分にあり，分 布が安定になるまでの統計期間の資料を使用する必要がある。

(2) さらに雨量階級別度数分布型を各地点で求め, 数量的な基準を求めることによって, 区分 をより客観化する必要がある。

2.3.2 地域による度数分布型とその安定性

2.1 で指摘したように, 日雨量 $\geqq 50 \mathrm{~mm}$ 以上の雨量階級別度数は指数型分布を示す。これに $\geqq 0.1 \mathrm{~mm}, \geqq 1 \mathrm{~mm}, \geqq 10 \mathrm{~mm}$ などの日雨量 $50 \mathrm{~mm}$ 以下の階級の度数分布を加えても同様の分布を示

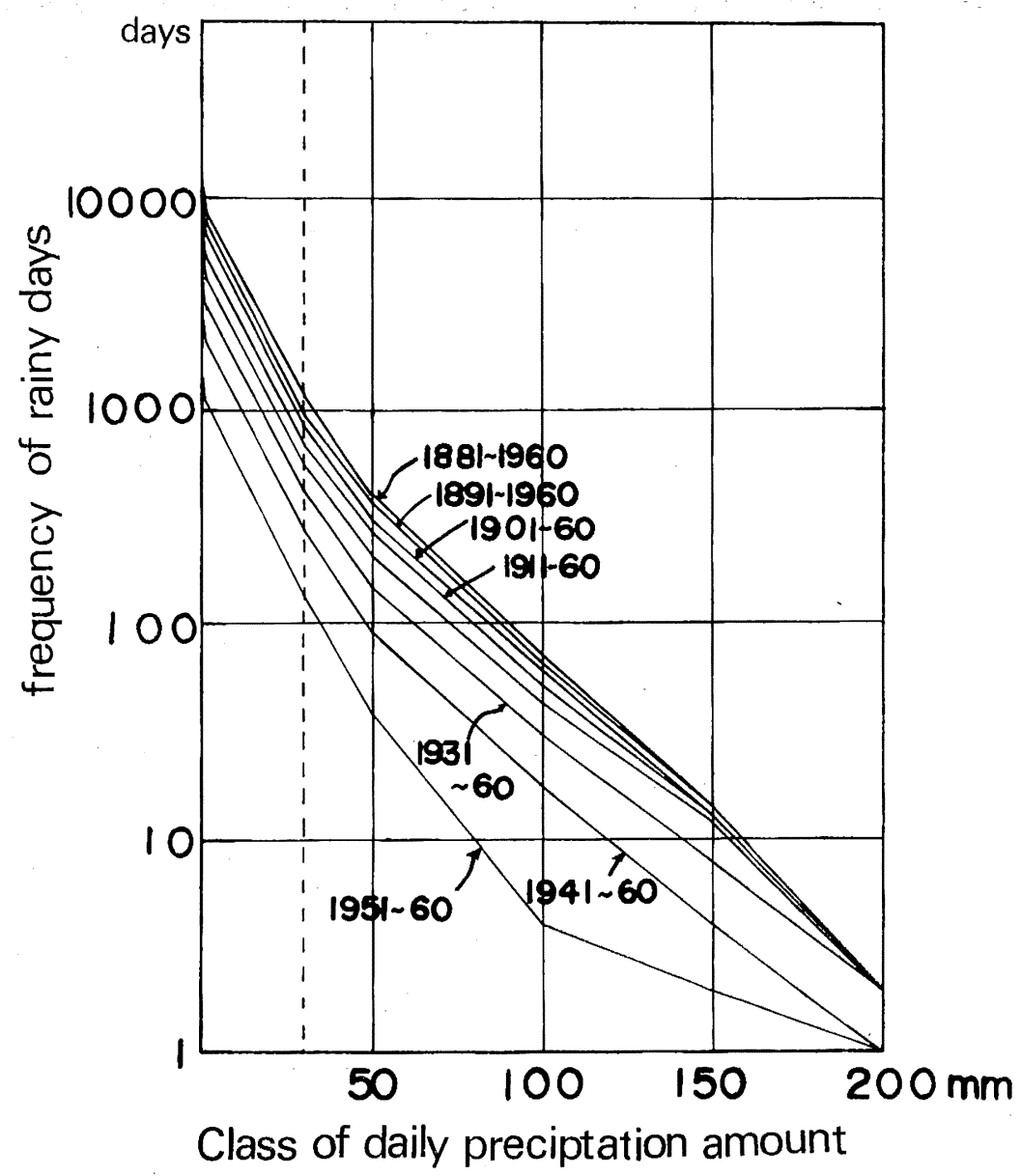

Fig. 10. Variation of the frequency distribution of the classified daily precipitation amount according to the period of observation (Tokyo). 
す。この指数型分布を各地点について見ると，地域区分によってそれぞれ特有の分布型を示し ている。その 1 例として高田 (冬季多発型, 日本海沿岸), 長野 (年間少数型, 中部地方内陸 部), 静阔 (年間多発型, 太平洋沿岸) の $0.1 \mathrm{~mm}$ 以上の日雨量階級別度数分布を Fig. 9 に示 した。度数分布曲線の傾斜は長野が最も急で, 静岡が最もゆるやかであり, 高田は $10 \mathrm{~mm}$ 以下 の階級で他地点より急速な日数の増加を示している。すなわち, 明らかに3地点の属する地域の 特性を備兄，分布型に違いが現われている。

図に示したのは 1 例であるが，これらの地点の属する地域区分内の他地点は，それぞれ類似 の分布型を示す。それゆ兄，再現期間あるいは超過確率の計算をする場合には，大雨の地域区 分每に地点を選び計算しなければならない。そして，大面の地域区分が次節に述べるように， 福井英一郎の分類による気候区分にほぼ一致していることから，ある地点の資料で計算した再 現期間は，その地点の属さない他の気候区に適用してはいけないことを示している。

また，雨量階級別度数分布は，統計期間が短いと安定性が悪くなる。何年間の統計によって 安定した度数分布型が得られるかは，確率計算を行なら場合に問題となる。Fig. 10 は統計期 間の長い東京について検討した結果で，1960 年から10 年毎に過去にさかのぼり，各雨量階級別 度数を積算した值を図にしたものである。最終の統計期間は1881〜1960年の80年間であるが, 50 年以上になると安定した分布型になっているようである。他の地点について同様に検討した 結果からも，50年以上になると安定した分布型を示すようになる。

安定した度数分布型が与党られれば，それによって指数型分布に拈ける係数決定を行ない, さらに前節で述べたように，大雨の地域区分を゙吟味することが可能となる。そして，安定した 分布型を基として各地域区分毎の大雨の再現期間を求める確率分布を与えることが可能となる はずである。

\section{2 .4 従来の区分との対応}

大雨日数による地域区分が，大雨だけに特徵的に現われるるのであるか，他の気候要素によ る区分に従った分布をしているかが問題である。

本邦の気候区分としては，KÖPPEN や THORNTHWAITE の方法に上る気候区分，あるい は降水要素炎の他の気候要素の組み合わせにより，福井英一郎，関口武らによって数種の気候 区分が提出されている。われわれの大雨日数から見た地域区分は, それらの中で, 福井英一郎 の1933年に提出された気候区分に最も近い分布を示す。（福井の気候区分は精細であるのに対し て，われわれの区分は大まかである)。

福井英一郎の気候区分は，大区分（第 1 次分類）として気温を使用，中区分（第 2 次分類） として降水量およびその季節変化を，小区分（第 3 次分類）として小地形の影響を受けやすい 降水 (量と季節変化), 霜・雪・結水の日数と期間, 地方風などが使用され，大体の区分が決定 されている中区分に打いて降水量特よびその季節変化が使用されている。降水要素のとり方に 違いがあるが，われわれの地域区分とほぼ一致しているのは，年降水量とその季節変化を中心 に，隣接地域との相対的な違いをとり出す方法で行なわれたためと考える。年降水量や降水量 の季節変化は, 大雨日数の季節変化, 特に日降水量 $\geqq 100 \mathrm{~mm}$ の大雨日数のとれとは良い対応 を示さない。しかし，地域間の相対的な違いを見る限りに扣いては，年降水量と月降水量によ る季節変化にも，違った形での地域差が現われ，これがわれわれの地域区分と一致するような 分布をすることによって，福井の気候区分との一致を見たすのと思われる。 
な浐，土屋正孝 (1960) は日降水量 $1 \mathrm{~mm}$ 以上の降水日数によって求めた降水密度を基にし て地域区分を行なっているが，われわれの地域区分とは一致しない。何故に一致しないかは， 今のところ不明である。東京の 80 年間の資料について，各年の $\geqq 50 \mathrm{~mm}$ 㐨よび $\geqq 100 \mathrm{~mm}$ の大雨日数と $\geqq 0.1 \mathrm{~mm}$ をとった場合の降水密度拈よび $\geqq 1.0 \mathrm{~mm}$ の降水密度との相関を調べ た結果では両者とも相関はほとんど等しい。あるいは3.1節で示すような両者の関係に顕著な地 域性があることに原因しているのではないだろらか。

\section{3. 大雨地域特性の動気候学的考察}

\section{1 大雨日数と降水密度}

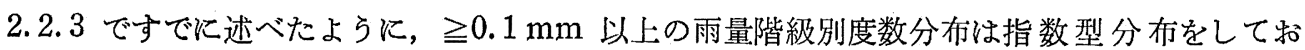
り，しかも，度数分布曲線の傾斜は大雨の地域区分に対応した現われ方を示している。この関 係を考慮に入れた気候要素を用いることによって，大雨日数による地域区分が気候学的に意義 のあるものであることを明らかにすることができる。その意味で降水密度との関係を検討した。

3.1 .1 降水密度と大雨日数との関係の理論的考察。

第 1 報に扔いて，すでに日雨量 $0.1 \mathrm{~mm}$ 以上の雨量階級別雨天日数が指数型度数分布をする ことから，理論的に降水密度が大雨の地域区分を与える指標となりらることを証明したが，一 部数式の取り扱い方を誤って特るのと，議論を進める都合上，再論することとする。

指数型度数分布は

$$
f(R)=\beta e^{-\beta R}, \quad R \geqq 0
$$

で与えられる。また，日雨量 $0.1 \mathrm{~mm}$ 以上の全階級別度数の総和を 1 とすれば,

$$
\int_{0}^{\infty} f(R) d R=1
$$

は明らかでめり, 減衰率及は最尤法によって

$$
\beta=\frac{1}{\bar{R}}
$$

で与觉られる。しかるに, 平均降水量

$$
\bar{R} \equiv \frac{\text { 降水量合計值 }}{\text { その期間の } 0.1 \mathrm{~mm} \text { 以上の日数 }} \equiv \text { 降水密度 }(D)
$$

である。ゆ无に減衰率は

$$
\beta=\frac{1}{D}
$$

で与えられる。

そこである雨量階級 $R_{0}$ 以上の $R$ が現われる確率は，(1)式と(2)式から

$$
\int_{R_{0}}^{\infty} f(R) d R=e^{-\beta R_{0}}=e^{-\frac{R_{0}}{D}}
$$

となる。よって, 降水密度 $D$ が大ならば $R_{0}$ 以上の $R$ の現われる確率は大きくなり, 
$D$ が小ならば確率は小さくなる。

$R_{0}$ として $50 \mathrm{~mm}, 100 \mathrm{~mm}$ を入れ，各地の降水密度によって実際に確率分布を求めれば, 大雨日数の分布図に対応する分布が求められるはずである。

すなわち，日雨量の $0.1 \mathrm{~mm}$ 以上の各雨量階級別度数分布が指数型であるといら条件から， 降水密度が大雨日数の地域特性を与兄るよい指標となりらることが証明される。

ただし，この議論は(1)式で表わされるような単純な指数型分布の場合には当てはまるが，実 際に各地点別の度数分布を見ると，単純な指数型分布ではない（Fig. 9 参照）。それゆ克，直 ちにこの関係を大雨の再現期間あるいは超過確率計算に適用することはでさない。

以上，われわれは雨量階級别度数分布が単純な指数型であると仮定することによって，降水 密度と大雨日数との関係を導いたのであるが，各地点に搞ける実際の度数分布は単純な指数型 ではない。そこで，実際資料を用いて解析的にこれらの関係を吟味する必要がある。

3.1 .2 大雨日数と降水密度との関係の解析。

雨天日数として日降水量 $\geqq 0.1 \mathrm{~mm}$ の日数をとり，月をたは年の総降水量を同期間の雨天日 数で除した值をもって，月または年の降水密度とした。

まず, 全国気象官署について, 各地点の1951 60年の各月平均降水密度と, 同期間の $\geqq 30 \mathrm{~mm}$,

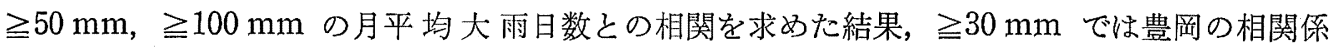
数が 0.55 という低值である以外は，Fig. 11 に示すように高い相関分布を示している。

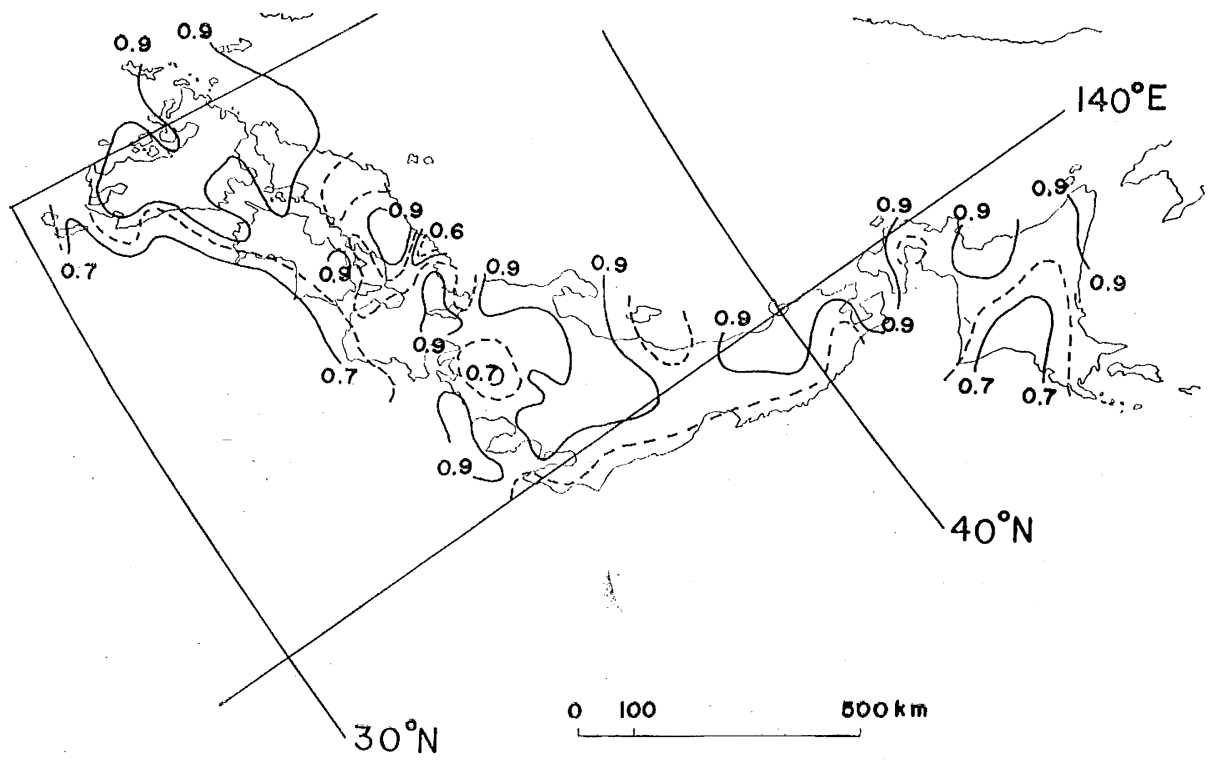

Fig. 11. Areal distribution of the correlation coefficient between the monthly mean frequency of heavy rainfalls (daily precipitation amount is $\geqq 30 \mathrm{~mm}$ ) and the monthly mean railfall density (1951-60).

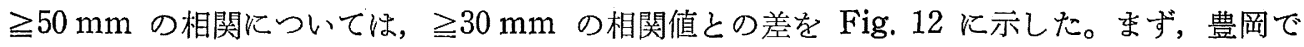
あるが，図から明らかなように，相関係数は 0.72 と高くなる。一般的傾向として，大雨の少発 域で $\geqq 50 \mathrm{~mm}$ の相関が低くなり，多発域で高くなっていることがわかる。 


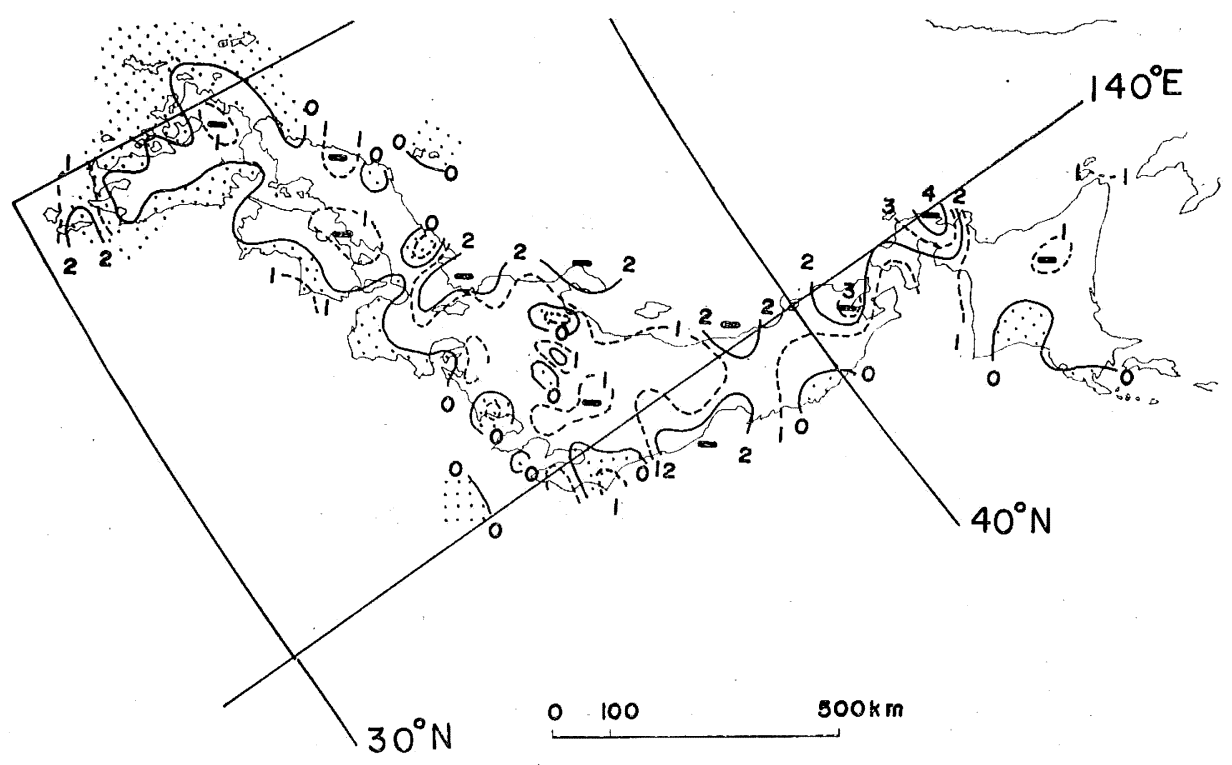

Fig. 12. Difference in correlation coefficient of the monthly mean rainfall density between the case of $\geqq 30 \mathrm{~mm}$ and the case of $\geqq 50 \mathrm{~mm}$.

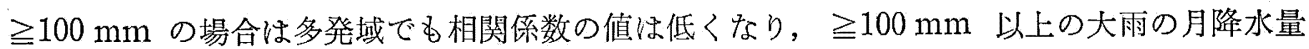
に対する寄与度は，大雨多発域に虰いても少なくなることを示している。

次に各地点の年平均降水密度と 10 年間の $\geqq 30 \mathrm{~mm}, \geqq 50 \mathrm{~mm}, \geqq 100 \mathrm{~mm}$ の各雨量階級別大 雨日数の年間合計值との関係を調べた。その結果, ミ30 mm の場合は降水密度との関係は直線 的であるが, ミ50 $\mathrm{mm}$ と $\geqq 100 \mathrm{~mm}$ の場合とは降水密度 $8 \sim 9 \mathrm{~mm} /$ day 付近以上と以下とで 分かれる 2 直線で関係が示される。

$\geqq 50 \mathrm{~mm}, \geqq 100 \mathrm{~mm}$ の大雨日数と降水密度との関係が 2 直線で示されるのは何故か, さらに, それらの関係が地域的に違いを示していないかを検討するために，地域別の関係を調べた。

Fig. 13 は地域別に区分した $\geqq 50 \mathrm{~mm}$ についての結果を示したものである。地域区分は, 内 陸部 (年間少発域), 日本海沿岸 (冬季多発域), 太平洋沿岸 (年間多発域), 九州 (暖候期多発 域), 内陸部中間領域とした。両内陸部と日本海沿岸は緩傾斜の直線上に乗り, 年間少発域, 冬 季多発域, 中間領域の順に, 降水密度に対する大雨日数の割合が多くなっている。太平洋沿岸 と九州は急傾斜の直線上に乗る。な拈, 降水密度に対する大雨日数の割合が異常に大きい地点 があるが，とれらは太平洋側の島と阿蘇山である。

降水密度と大雨日数との間に以上のような地城性があることは, 前述の相関解析と相まって, 降水密度を画一的に大雨日数の指標として全国的に適用しえないことを示している。上述のよ うな地域性を考慮に入れて用いれば，降水密度は大雨日数のよい指標となりうる。

降水密度と大雨日数との関係に以上のような地域性がある原因は, 流入水蒸気量に地域性が あるためである。年間少発域はいずれる流入水蒸気量の少ない地域であり, 日本海沿岸の冬季 多発域も冬季の相対的に水蒸気量の少ない時期に, ほとえど連日の降水の間に発生する豪雪が $\geqq 50 \mathrm{~mm}$ となるのであるから，以下の日数が $\geqq 50 \mathrm{~mm}$ 以上の日数に比して当然多くなる。 


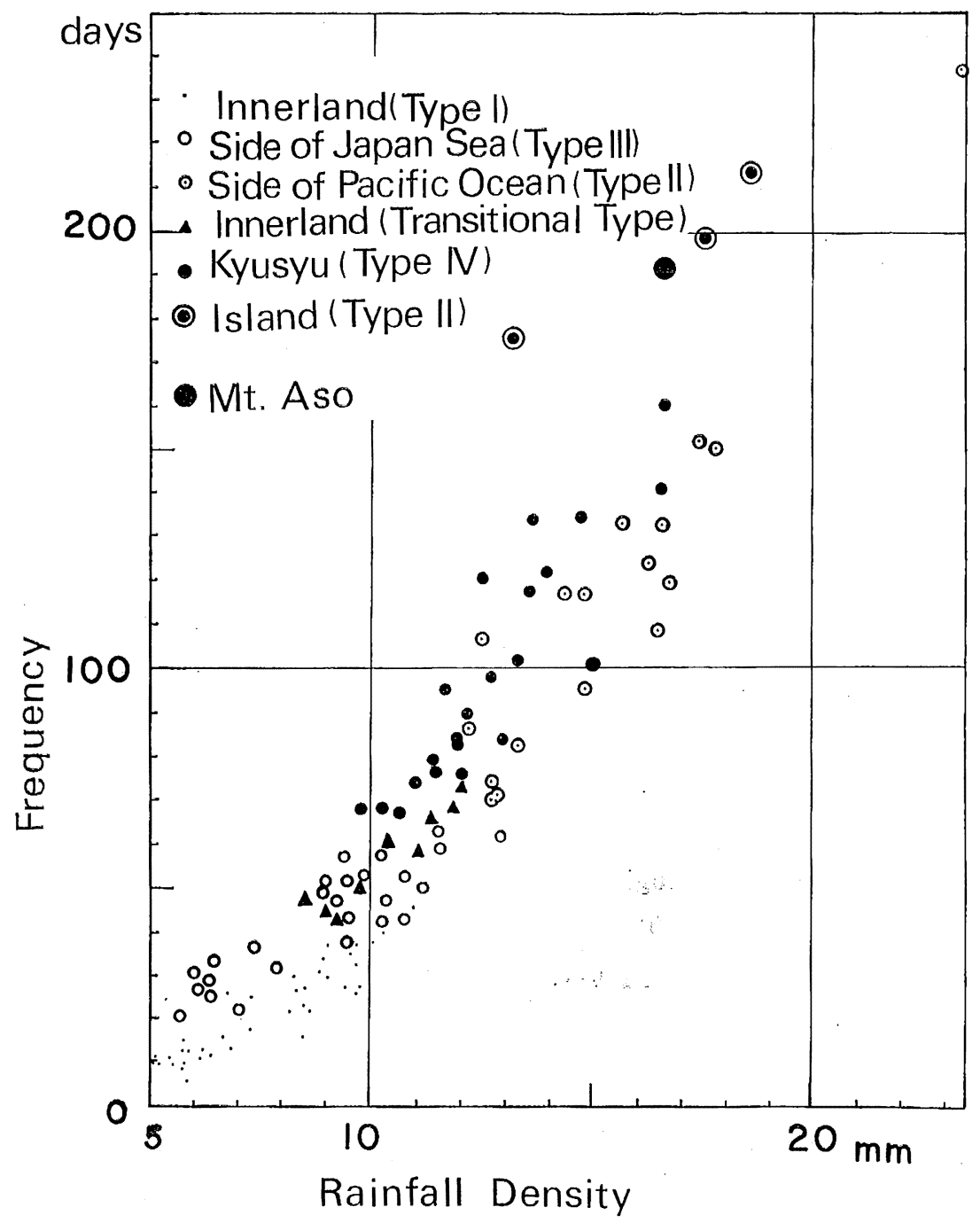

Fig. 13. Areal difference in the relation between annual mean rainfall density and annual frequency of heavy rainfalls $\geqq 50 \mathrm{~mm}$.

多発域はいずれも流入水蒸気量の多い地域に当り，気象じょう活通過時の一雨雨量が多くなる 地域である。な执，水蒸気量と大雨日数との関係は後述する。

\section{2 大雨日数と高度との関係}

\section{2 .1 山岳と隆接平野部との関係}

高度による降水量の違いについては，山岳気象観測がはじまって以来，特に，明治 44 年 (1911)の森林治水事業の一環として森林測候所が開設されてから，多くの研究がなされて来た。 そして海抜高度と雨量との関係が降雨の原因によって異なることも明らかにされて来ている。 たと觉ば，伊吹山の山岳雨量を取り扱った児玉良三 (1954) は，「伊吹山の南斜面では中腹に極 大がでるのは低気圧, 梅雨前線, 台風のときで, そのときの雲底高度と風速によって, 山頂と 
山麓のどちらが多量になるかがきるる。雨量が高度とともにあまり変化しない場合は，原因は いろいろ另るが，いずれも風速が弱いとき，また，山頂が最大で山磇が少ないときは低気圧， 前線通過後の北西風のときまたは山頂よりも雲底高度が高い場合であった」と述べている。

われわれが取り扱ら大雨日数は年単位のものであり，児玉その他の人々が行なっているよう な気象じょう乱別の分析はできない。また，山地に括ける海抜高度の月または年の雨量との関 係について多くの実験式が提出されているが，われわれの取扱った 137 地点の地理的分布から いって，同様の議論をすることはできない。従来の研究は降水量の高度による違いについて行 なわれているもので，大雨日数の高度による違いについてはまだなされていない。この研究で は不十分な資料ではあるが，若干の検討を試み，第 1 報に報告した（p. 303〜305，Figs. I. 11， 12，特よび Table 9)。

その要約を述べると次のようになる。

(1) 温泉岳一長崎, 温泉岳一熊本, 阿蘇山一熊本, 中宮祠一宇都宮の各組み合わせ飞よって,

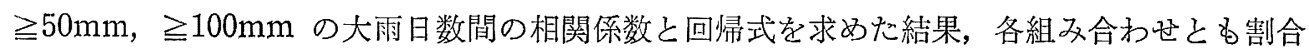
高い相関があり，温泉岳一長崎の組又合わせを除いて，1.4１.6倍の比率で山岳官署の方が 多くなっている。

(2) この山岳官署の大雨日数が隣接平地官署の 1.4 1.6 倍という比率は, 阿蘇山一熊本，中宮 祠一宇都宮の年降水量によって求めた回帰俰数とほぼ等しく，また，只見川上流高峯斜面の 標高と積雪相当水量との間に現われる関係もほぼ同様の値を示す。

(3) 温泉岳一長崎の組み合わせのみは，上記のような高度差による関係が現われないが，これ は，次節で述べるように湿潤不安定気流の直接流入しやすい海岸近傍にある長崎近傍では，海 面と陸地起伏との間の粗度 (Roughness length) の違いによって, 大雨発生の一つの条件で ある気流収束帯が形成されるためであると考它られる。

\section{2 .2 海面と陸地との地面摩擦の違いによる影響}

1959年 Woods Hole で開催された Cloud Physics Conference そ䄮いて，T. BERGERON は冒頭講演 “Problems and Methods of Rainfall Investigation”を行なったが，その中で， 海岸付近飞持ける地形性降雨の増大を次のように指摘した。すなわら, 南西スカンジナビア海岸 に扣ける前線性降雨をとりあげ，海岸近傍では，山岳によって強制された収束 (orographically conditioned convergence) によって雨量が増大すると結諭した。これに対する討諭に和いて， C. W. NEWTON は，南西ルイジアナ州の山岳効果があると思われるような大きい山脈を欠く 海岸地域で，やはり雨量分布に多い地域が㐫り，これから考㝋ると，山脈によるよりは，海上 と陸上との摩擦効果の違いによって雨量が增大するのではないかと指摘している。

以上のような海岸付近で多雨の事実は,

(1) Fig. 3 に示した西日本に执忷る大雨日数の地域分布にも現われて特り, 特に紀伊半島に顕 著に現われている。Fig. 4 の紀伊半島に和ける大雨日数年間総数の分布でも海岸からの直線 距離 $20 \sim 25 \mathrm{~km}$ の地带に大雨日数の多発帯がある。

(2) 東支邦海沿岸の平戸，佐世保，長崎と，内陸部に入った佐賀，熊本，有明海沿岸各地点と では，東支邦海沿岸各地の方がいずれも多雨であること，そして，前節で述べたように，温 泉岳の大雨日数が長崎より高度が高い山岳官署であるにもかかわらず，長崎よりそれほど多 くはないこと。 
などに現われている。

われわれはここで, 彼等の提起した海岸付近に和ける雨量增大の原因について, 最近の諸家 の研究，特に乱流論の成果によって若干の検討を加えることとする。

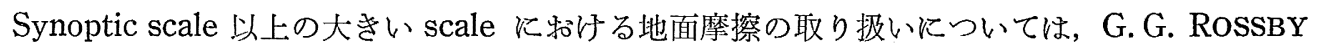
\& R. B. MONTGOMERY (1935), R.C. SutTClIFFE (1936) 等が取り上げて以来, 多くの人 々によって研究されて来て执り，1959年に J.S. SAWYER が数值予報に括ける地形効果の取り 扱いを (a下部刘流圈飞和ける small-scale の乱流，(b)成層圈飞まで桩がる重力振動，(C)地衡風 的平衡のまわりに拉ける振動, (蕉地衡風的運動に分けて諭じ, (a乱流運動のSynoptic-scale 以上のものに対する影響は省略できるとした。翌1960年, G.P. CRESSMAN 海面と地形起伏の 異なる陸地の抵抗係数を過志の諸研究を基にして与兄, 北半球の数值予報を Barotropic-model で行ない。海陸の抵抗係数 $\mathrm{C}_{\mathrm{D}}$ の相異を数值予報モデルの中に入れる必要性を強調している。こ れらはいずれも格子間隔が $150 \mathrm{~km}$ 以上の scale に和ける地形起伏の大気運動に対する影響を論 じたもので，平滑化された地形を取り扱ったとも考えられる。

一方, 乱流論の立場からのこの問題に対する研究は境界層の問題として, 風洞実験, 野外に 特ける micro-scale の実験が重ねられ，理論的研究も，例兄ば，R.J. TAYLOR (1962) など によって展開されている。

しかし，これら乱流論に特ける研究が，われわれの対象としている meso-scale から smallscale に怙ける運動にそのま適用できるとは，相似則の関係から簡単には言えない。われわれ の対象としている問題はまだ末解決といらよりは，末だ， ほとんど手のつ方られていない分野 に属するるのである。

われわれはここで定性的にではあるが，その影響を吟味してみる。海面と陸地との地面摩擦 の違いは Roughness length $\left(z_{0}\right)$ あるいは抵抗係数 $\left(C_{D}\right)$ の違いで表示される。

長崎付近の平均高度は， 5 万分の 1 地図から緯度・経度 $1^{\prime}$ 毎の海抜高度を，長崎一温泉岳の 緯度を中心とする $32^{\circ} 40^{\prime} \mathrm{N} \sim 32^{\circ} 50^{\prime} \mathrm{N}$ の東支那海から橘湾までの経度の範囲で読み取った結果,

約 $200 \mathrm{~m}$ となる。

根本茂(1968) が気象仃観測塔に和ける台風による強風時特よび弱風時の観測記録により $z_{0}$ を 求めたが, 弱風時では $1.9 \mathrm{~m}$, 強風時には $1.8 \mathrm{~m}$ という值を得ている。気象庁周辺の建物の平 均高度を $30 \mathrm{~m}$ ととると, 弱風時の場合の $z_{0}$ は平均高度の約 $1 / 15.8$, 強風時には約 $1 / 16.7$ であ る。これらの平均高度と $z_{0}$ との関係を用いて, 長崎付近の $z_{0}$ を求めると, 強風時の場合は 12.4 $\mathrm{m}$, 弱風時の場合は $12 \mathrm{~m}$ となる。われわれの目的は地面摩擦の粗度による相違をオーダー的に 推定しようとするのであるから，強風時の $12 \mathrm{~m}$ を $z_{0}$ として採用する。

C. H. B. PRIESTley (1959) により,

$$
C_{D}=\left(\frac{u_{*}}{u}\right)^{2}
$$

で与兄られる。ここで $v_{*}$ は摩擦速度, $u$ は風速であり，これらと $z_{0}$ との関係は Sutton (1953) により,

$$
\frac{u}{u_{*}}=\frac{1}{k} \ln \frac{z}{z_{0}}
$$

故に 


$$
C_{D}=\frac{1}{\left(\frac{u_{*}}{u}\right)^{2}}=\frac{1}{\left(\frac{1}{k} \ln \frac{z}{z_{0}}\right)^{2}}
$$

ここで, $k$ は Kármán 常数で, 0.4 である。

上式に, $z=200 \mathrm{~m}, z_{0}=12 \mathrm{~m}$ を入れて計算すると，

$$
C_{D}=0.0202=2 \times 10^{-2}
$$

となる。

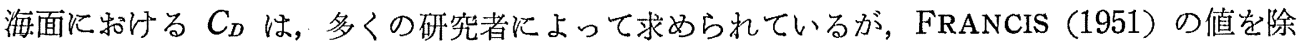
き, $10^{-3}$ のオーダーでわれわれの取り扱っている地形起伏の場合の陸地の抵抗係数よりも 1 桁 小さい。

われわれの場合には定性的な議論しかできないのであるが， $C_{D}$ が 1 桁異なるよらな不連続な 境界面があった場合にその上空を流れる気流に対する影響は次の 2 通り考兄られる。

(1) 等圧線と風向とのなす角が大きく変わる。W. A. L. MARSHALL (1954) によれば，海上 での等圧線と風向とのなす角は約 $6^{\circ}$ であり, 陸上では一般に約 $30^{\circ}$, 山岳地帯では約 $35^{\circ}$ とな る。

(2) $C_{D}$ の相違により, 海面上から流入する気流は陸上に入って，少なくとも摩擦層内に扣ける 気流は乱れ，風速は減少する。

これら 2 通りの影響の仕方によって，海岸近傍では収束帯が形成されることとなる。抵抗係 数 $C_{D}$ は Rougness length $z_{0}$ が高ければ大きい值となるので, 海岸地帯の海拔高度が急に高 くなるような地形のところでは，これ等の効果による収束が大きくなり，それだけ降雨強度を 増すこととなる。

以上のような地面摩擦による効果（粗度効果と呼ぶ）によって，すでに述べた紀伊半島の大雨 多発帯と東支那海沿岸の大雨の地域性を解釈して見よう。

a ) 紀伊半島の大雨多発帯

2.1.4 に特いて，中国地方の日本海側四国特よび紀伊半島の太平洋に面した地方では，海岸 からほぼ等しい距離の地帯に大雨の多発帯が見られ，紀伊半島のそれが特に特徽的であると述 べた。紀伊半島の多発帯は海岸からの距離 $20 \sim 25 \mathrm{~km}$ の線を軸とする地帯に見られる。この多 発帯の存在は, 上記粗度効果によって形成される収束帯によって説明される。

大雨多発帯が海岸ではなく，海岸から 20〜 25km 離れた地帯に存在する理由は次のように考 えられる。

紀伊半島へ湿潤不安定気流が南西〜南東の範囲の風向で海上から流入し，年の気流内ですで に海上に特いて対流雲が発生し，成長しつつ陸上に向かっているとする(豪雨時のレーダー・エ コー写真によれば，このような対流雲が次々と陸上に向かって来る事実が観測されている)。

海上から対流雲が陸上に進入して来る際，粗度の違いによる海岸近傍の収束帯の影響を受け て，対流雲内に物ける収束上昇は加速され，対流雲の発達が加速されることとなる。

対流雲が発達して降雨が発生するまでには時間を要する。豪雨時の対流雲内に括ける上昇速 度は平均 $5 \mathrm{~m} / \mathrm{sec}$ 以上，速い場合には $10 \mathrm{~m} / \mathrm{sec}$ という観測もある。豪雨をもたらすような一 般的気象条件下にあって，成長しつつある対流雲が，上記沿岸部の収束帯の影響を受けて上昇 気流が加速され，急速に発達して巨大積乱雲になることは考兄られることである。もし，収束 


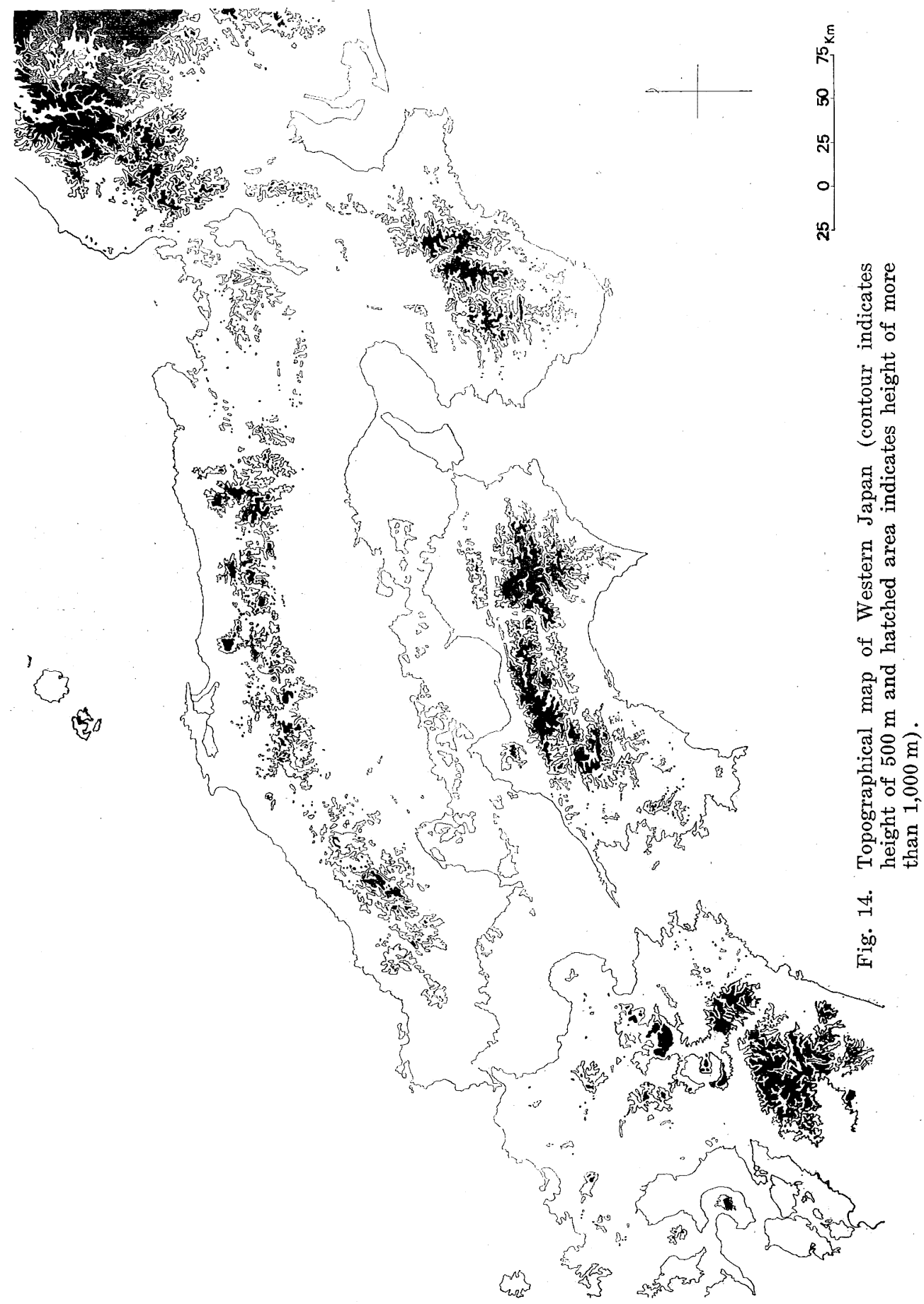


帯の影響がないならば，海上で成長した対流雲は，上陸することによって勢力を消籷し，従っ て降水量の分布も沿岸から内陸部に行くに従って漸減の形をとるはずであるし，地形による強 制上昇が VDH で表現されるような単純なるのならば，地形勾配の急なところと大雨多発域と が一致すべさであるのが，必ずしも一致していない。(Figs. 3, 4 と Fig. 14 を参照されたい)。 対流不安定下にあって，成長しつつめる対流雲が上記収束帯に到達した場合には，上昇気流 の速度が加速されて，5 10 m/sec という強い上昇速度の発生も考兄らることであり，その 際，巨大積乱雲となるまでに要する時間は 30 分以内である。その間に生成された雨滴が地面ま で落下するに要する時間は約 10 分である。一方，その間に積乱雲は一般流に流されるが，一般 流を日本付近に和祃る気象じょう乱の平均速度 $40 \mathrm{~km} / \mathrm{hr}$ と仮定すると, 雨滴の落下地点は海岸 より $24 \mathrm{~km}$ 風下の地帯を中心とした内陸部に形成されることになる。

b）東支那海沿岸の大雨地域性

長崎と温泉岳の大雨日数間には高度差による差があまり見られない。その理由も紀伊半島の 大雨多発帯と同じように説明することが可能である。

長崎は東支那海岸からの距離が約 $7 \mathrm{~km}$ のところにあって, 上記粗度効果による収束帯の影響 が現われはじまるところに当る。この収束帯の影響による大雨多発域は，紀伊半島の場合と同 様に東支那海からの距離 20〜25km の地岸に現われてよいはずである。長崎県内については区 内観測所による大雨日数の分布を調べるまでにいたらなかったが, 長崎海洋気象台発行の「長崎 県の気象」により累年平均年降水量の分布を見ると, 紀伊半島の場合と同様に, 諫早などの存在 する東支那海からの距離 $20 \sim 25 \mathrm{~km}$ の地帯の近傍に総降水量の多い地帯がある。雲仙岳の影響 は風下側に現われるはずであるが，そこは有明海である。粗度効果による収束帯の影響が長崎 にわずかではあるが現われる可能性があるのに対して，雲仙岳の南西斜面に位置して扬り，海 岸からの距離 $4 \mathrm{~km}$ 末満の温泉岳では, 山岳地形による強制上昇の影響はあっても, この収束帯 による降雨量の増大は期待され難い条件にあることが，両者の大雨日数に，他の山地官署と隣 接平地官署とのような関係を見出しえない原因となっていると考它られる。

以上，典型的な例について，粗度効果による収束帯の形成が大雨多発域の地域性に微妙な影 響を与兄ていることを示した。定量的な吟味をしたわけではない。これらの問題は, 将来数量 的に確めらなれければならないし， meso-scale の実際の大気現象に適用できるような乱流論的 な研究も，観測技術の進歩によって，近い将来に発展するものと信ずる。

洋上から陸上に上陸して来た対流雲が, 上陸点近傍でェコー強度を増し, 発達することはレ ーダー観測によって確められていることでめる。

\section{3 大雨の地域的特性の要因}

大雨・豪雨となるための要因をまとめると次のようになる。

(1) 多量の水蒸気量を含有した気団の流入があること。

(2) 激しい上昇気流がある特定地域に存在すること

これら (1)，(2)の要因は，いずれか一方を欠いた場合には大雨とならない。以下，これらの要 因と大雨との関係について述べる。

\section{3 .1 水蒸気量による大雨日数の制約}

大気中に含有される水蒸気量は気温によって左右される。気温の大まかな分布は緯度によっ て決定され，それに海流分布が影響を与光る。これらのことは事新しく論ずるまでもないこと 
である。さきに 2.1.1 で述べたように，大雨日数は緯度によって变化し，その緯度による変化 傾向は $36^{\circ} \mathrm{N} \sim 37^{\circ} \mathrm{N}$ を境として南北で異なることも明らかにした。気温の低い北海道, 東北地 方で大雨日数が少なく，相対的に気温の高い関東以西の太平洋岸で大雨日教が多くなるのる当 然とい方る。

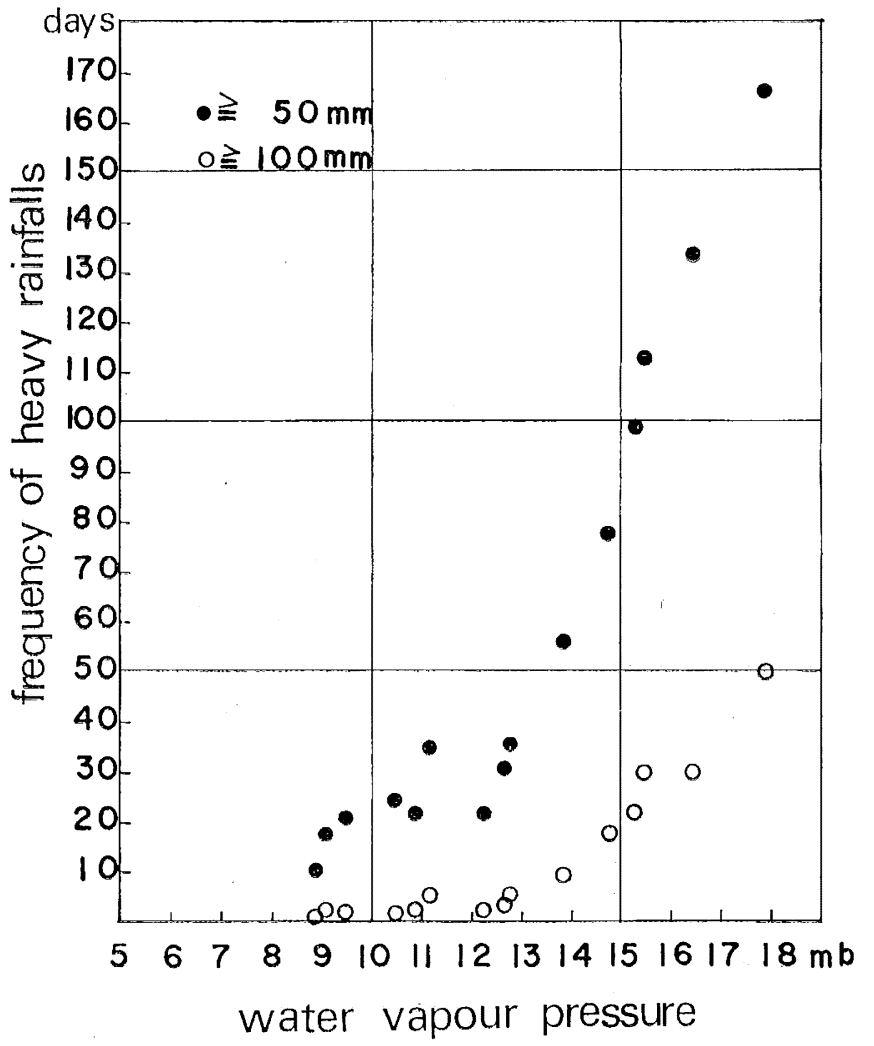

Fig. 15. Relation between the latitudinal mean frequency of heavy rainfalls and the latitudinal mean of the normal of water vapour pressure in each degree of latitude in Japan (1951$60)$.

Fig. 15 注日本全国気象官署の年水蒸気圧平年值を，2.1.1 で行なったと同様の緯度 $1^{\circ}$ 毎に 平均し，同じく平均した緯度毎の平均大雨日数との関係を示したものであるが，明らかに水蒸 気圧と大雨日数との間に密接な関係が見られる。すなわち， $13 \mathrm{mb}$ 付近を境として，それ以上で は水蒸気圧の減少に従い大雨日数も減少する傾向を示すが，減少傾向は極めて緩慢である。そ れに対して, 約 $13 \mathrm{mb}$ 以上では $\geqq 50 \mathrm{~mm}$ でも $\geqq 100 \mathrm{~mm}$ でも, 水蒸気圧の増加に伴う大雨日 数の增加が著しくなり，増加傾向もほぼ值線的である。

個々の気象官署を基にして，年水蒸気圧平年值と 10 年間の大雨日数との関係を見た場合には， 水蒸気圧 $13 \mathrm{mb}$ 前後に関係曲線の屈曲点が現われるのに変わりがないが，13mb 以上の領域での 水蒸気圧と大雨日数との間には linear な関係は見られない。（Fig. I, 13，p. 306 参照）これ は, 各気象官署の大雨日数には，水蒸気量以外の地理的位置からくる影響が大きく効いている 
ことを示するので, 緯度毎の空間平均をとることによって, 緯度以外の地理的条件(島, 沿岸, 内陸，山需，海流等々）の違いによる影響を除去することができたために，水蒸気压と大雨日数 との関係が明らかとなったのである。

多量の水蒸気を含む湿潤気流の流入が大雨の必要条件であることは, 以上の事実から明らか である。さらに，大雨の地域性に関して水蒸気量との関係を問題にしたい。

日本上空に多量の水蒸気をるたらす，その補給源は広大な海でする。海上からの水蒸気の補 給は蒸発によって行なわれる。この蒸発量は energy-balance method によっても, masstransfer method によっても, さらに, より厳密に解こうとする乱流輸送理論の立場からも, 水温と気温との差および海面上の風速勾配が大きく影響している。

冬季日本海沿岸の豪雪は以上の理由から説明される。すなわち, 大陸から南東進して来た新 鮮な寒気団は，暖流の流れている日本海上を通過してくる間に，いちじるしい水温と気温との 温度差から多量の蒸発が発生し，その結果，寒気団下層に熱と水蒸気の供給を受けて不安定化 し, 対流雲の発生によって豪雪が降る。それゆ兄, 新鮮な寒気団が日本海の暖流上を長い距離 通過するような気圧配置のとさに，日本海沿岸に豪雪が降るし，能登半島突端の輪島や佐度島 よりも，北陸・越後の沿岸地域の方が冬季の大雨 (雪) 日数が多くなる。特に大雨日数の多い高 田や敦賀は地形による気流の収束もあるが，日本海の幅が最も広い部分に当り，寒気団の変質 度合が日本海を通過して来た距離に比例し，その不安定化が極限に達する地域に高田や敦賀が あると考えることによって説明される。

暖候期に日本に運ばれて来る湿潤気流は, 村上多喜雄 (1959) 飞上る梅雨期の水蒸気収支の研 究によって明らかにされているょらに，台湾南東方の西太平洋や南支那海方面から運ばれて来 る。台風の北上・来襲によって，高湿な赤道気団が日本上空に流入することも，すでに気象界 の常識である。

また，太平洋岸の黒潮に洗われる地力も水蒸気補給の好条件をもつ。四国沖は日本付近に护 ける温帯低気圧発生地の一つであるが，気流の収束によるだけでなく，黒潮の影響も見逃せな い。房総半島以西の太平洋沿岸が年間を通じて大雨多発域となっているのは, 太平洋南岸沖が 低気珪絡となっているばかりでなく，黒潮流域からの水蒸気輸送もあずかっていると考兄ら れる。

水蒸気の補給が海洋上からなされるゆえ, 海洋上から気流の入り込みやすい地域が大雨の降 りやすい地域となるはずである。この点に着目して, 水越允治 (1962) は南南西〜西南西の風に よって水蒸気が運ばれる場合, 標高 $500 \mathrm{~m}$ 以上の山体の陰になる地域を西日本について求めて いる。それによると, 豊後水道, 紀伊水道の太平洋に向かって開放されているところで, 内陸 部に気流の入り达みやすい地域が現われて扣り，瀬戸内海沿岸中心域は山陰げ部分となってい る。大雨に関連する湿潤気流は, 水越の取り扱った西南西〜南南西の気流ばかりではない。南 東〜南の気流も多量の水蒸気を流入させる。南東〜南の気流の場合には，瀬戸内海沿岸につい て見ると, 水越の指摘した山除げ部分は西方に移動して現われる。Fig. 3 で 6 月と 9 月の瀬戸 内海地方に扣忷る大雨日数の相違は，6 月と9月の湿潤気流を流入させる一般流の，上記のよ らな相違によって現われる (Fig. 14 参照)。

湿潤気流の流入経路の相違は大雨少発域の分布に変化を与学るばかりでなく, 大雨多発域の 分布にも変化を与光る。紀伊半島に和壮る大雨日数の 6 月と 9 月との分布の間に明らかな相違 
が見られるが，この相違は上部と同一の原因によって発生しているものである。

一般流を潮胛の $850 \mathrm{mb}$ の風で代表させ，1951 60 年の各年に物ける6月と 9 月の風につい て, 風向が $91^{\circ} \sim 171^{\circ}$ と $191^{\circ} \sim 270^{\circ}$ の各出現度数と紀伊半島のほぼ同緯度にある東西両側の 大雨日数との関係を調べた。西側地点として東野上と川上を，東側地点として大杉谷と五郷を 採用し, 両地点の $\geqq 50 \mathrm{~mm}$ の大雨日数の合計值をもって, それぞれ東西両側の大雨日数とし

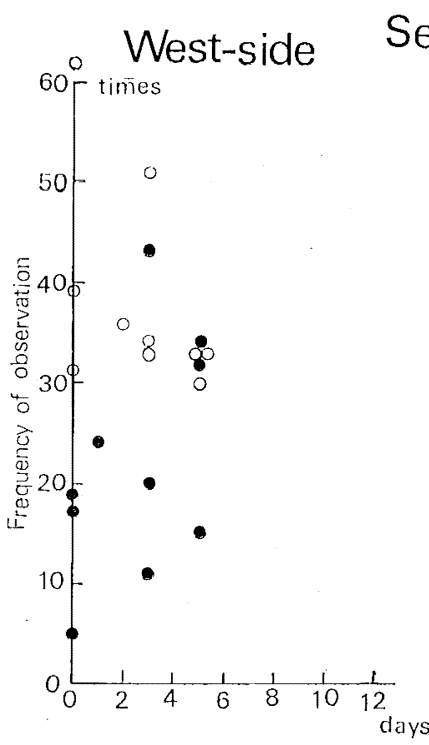

$\underset{\substack{\text { September } \\ \text { times }}}{\text { East-side }}$ days
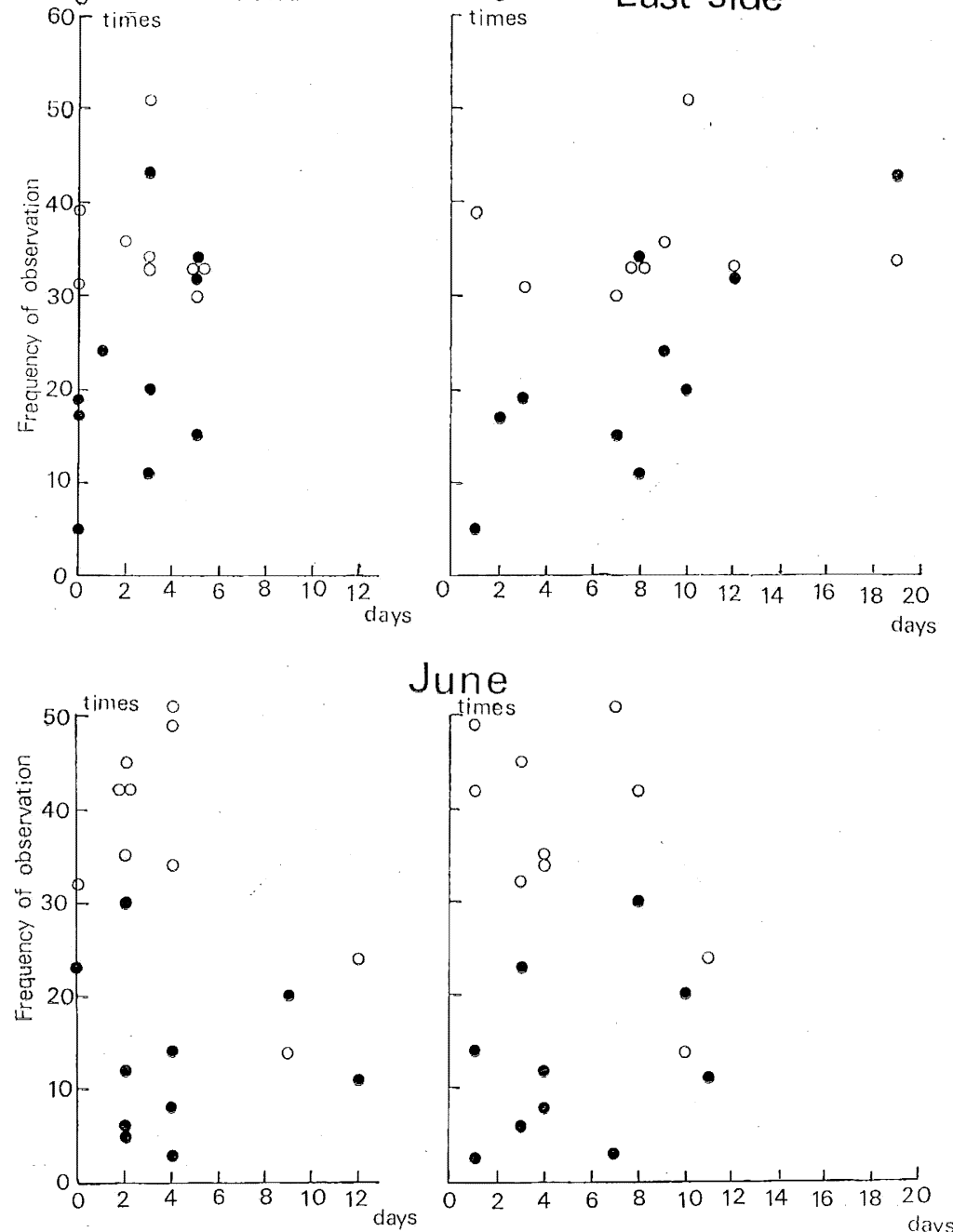

Frequency of heavy rainfalls

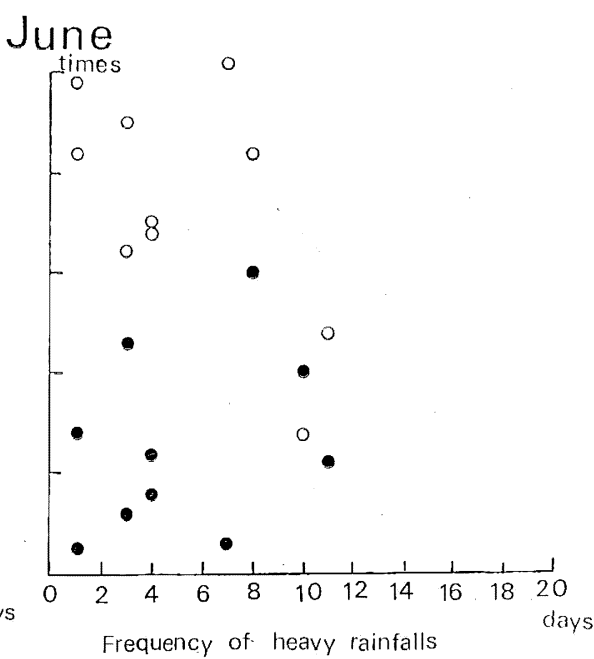

Fig. 16. Relation between appearance of heavy rainfalls at Wakayama and Owashi and upper wind of $850 \mathrm{mb}$ level observed at Shionomisaki. The white circle indicates that the daily precipitation amount at Wakayama is more than $50 \mathrm{~mm}$ but that the amount at Owashi is less than $50 \mathrm{~mm}$ or that the amount at Wakayama exceeds that of Owashi by more than $50 \mathrm{~mm}$; the black circle indicates an opposite relationship. 
た。風の観測は1日4回で欠測のこともあるが，実測回数を全部数えてある。Fig. 16 にとの結 果を示したが， $91^{\circ} \sim 170^{\circ}$ では，6月は東西両側とも相関関係が悪く，東側がからうじて正相関 の関係を示している。これに対して 9 月は，西側では相関関係が悪いが，東側では明らかに正 の相関となっている。

$191^{\circ} \sim 270^{\circ}$ の場合は，6 月は東西阔側とも負相関の傾向を示しているが相関が悪く，9月は ほとんど相関がない。

これらを総合すると，潮岬の $850 \mathrm{mb}$ 高度で東〜南南東の風が観測された回数が多い場合は， 紀伊半島の東側では大雨日数が多くなる傾向にあり，9月にはそれが明膫である。それに対し て西側では関係が明膫でない。南南西〜西風の観測回数が多い場合には，6月には東西両側之 もに大雨日数が少ない傾问に㠰るが，9月は核とんど関係がない。6月の $191^{\circ} \sim 270^{\circ}$ の回数が

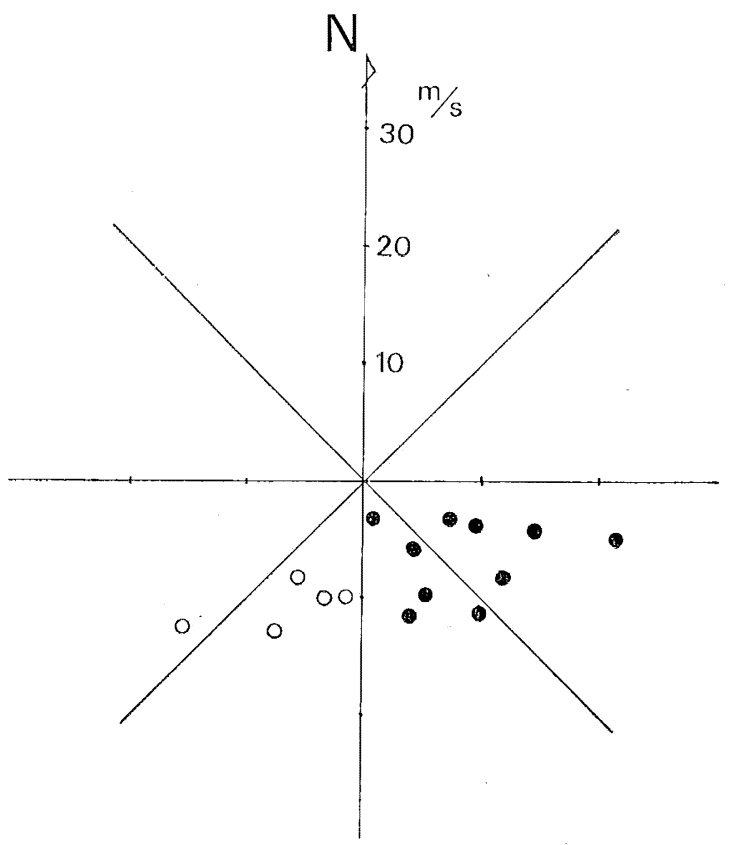

Fig. 17. Relation between the number of wind direction of $850 \mathrm{mb}$ level observed at Shionomisaki and the frequency of heavy rainfalls ( $\geqq 50 \mathrm{~mm})^{\prime}$ in June and Sept. on the east and west side of the Kii-Peninsula. (Frequency of heavy rainfalls is obtained at two stations; the white circle indicates the frequency of wind direction $91^{\circ}-170^{\circ}$, the black circle indicates that of $191^{\circ}-270^{\circ}$.

相関関係が悪いが負相関の関係にあるといらことが問題であるが，偏西風帯に属する潮岬で西 寄りの風の観測回数が多くなるのは当然であり，その西寄りの風のうち，湿潤暖気流となって いるものが大雨の原因となるので，その分離を行なわなかったために上記の結果が出たと考光 られる。

以上の結論を検討するために，尾熟と和歌山を東西両岸の代表地点にとり，いずれかの地点 
が日雨量 $\geqq 50 \mathrm{~mm}$ の大雨を観測した場合の潮岬に和村る $850 \mathrm{mb}$ 高度の風を調べた。その結果 をFig. 17 に示した。1954 年と 1961 年の 2 か年の 6 月のみであるが，尾鴊が $\geqq 50 \mathrm{~mm}$ の大雨 になっていて，和歌山が $50 \mathrm{~mm}$ 以下の場合は東南東〜南南東の風向に限られ，和歌山が $\geqq 50$ $\mathrm{mm}$ になっても，尾䉆とは日雨量で $50 \mathrm{~mm}$ 以上の差が出る。これに対して，和歌山に $\geqq 50 \mathrm{~mm}$ で尾鷲に降っても $50 \mathrm{~mm}$ 以下であるか，尾㲇の日雨量が $50 \mathrm{~mm}$ 以上少ない場合は西寄の成分 が入っている場合に限られている。

以上のような事実によって，湿潤気流の流入経路が大雨多発域の形成に重要な役割を占めて いることは明らかである。

\section{3 .2 上昇気流に地域的特性を与兄る要因}

激しい上昇気流がある特定地域に持続的に存在することが大雨・豪雨をもたらす一つの要因 であるが，上昇気流を与劣る要因はまた次のように細分される。

(1) 総観スケールの気象じょう乱 (台風, 温帯低気圧, 前線, 気圧の谷) の強いこと

(2) 大気成層が不安定成層をしていること，

(3) 対流不安定の解消が地域的に集中した形で行なわれること（集中豪雨，雷雨）

(4) 地形による強制上昇特よび強制収束上昇が強く発生すること（地形性降雨）

以下，これらの要因について述べて行く。

(1) 気象じょう乱と大雨の地域的特性

気象じょう乱の発生・発達・移動・衰弱がどの地域で, 何時の季節に如何に現われるかは, 大雨の地域的特性の主要部分を与光る重要な要因である。そして，気象じょう乱は広範囲に上 帠気流を与觉るばかりでなく，水蒸気を多量に本邦上空に流入させる主要な要因でるある。大 雨多発域の季節変化が気象じょう乱の季節変化と結びついて発生していることは，第 1 報扣よ び 1.1 .2 に沶いて明らかにした。ここでは，まず大雨多発域の季節変化を極東に括ける循環系 の季節変化から論じ，次に気象じょう乱の経路による地域的特性について述べることとする。

極東に招ける循環系の季節变化については, 倉嶋厚 (1968) の優れた研究がある。彼の提出し た日本付近の循環系の季節変化モデルを用いることによって, 大雨の一つの要因である水蒸気 の本邦への流入の季節变化をも含めて, 大雨多発域の季節変化が次のように統一的に把握され る。

(1) 3 月から 4 月にかけての大雨日数の急増と, 多発域の急激な拡大は, 冬季季節風の影響下 から中緯度季節風の影響下に入ることによって発生する。

(2) 前線度数の 4〜10 月の各月の多発域の移動・変化 (Figs. I, 10a, b, p. 301〜302) 牡よび 顕著低気圧の経路の変化 (Fig. I, 9, p. 300) から見ても明らかなように, 大雨多発域の季節变 化は寒帯前線帯および熱帯季節風の出現および季節変化と密接な関係がある。

すなわち，4〜6 月の大雨多発域の北上はあまり顕著ではないが，これは日本付近に括ける寒 帯前線帯の北上が同期間緩慢であることによって現われる。

また，6月から 7 月，8 月と大雨多発域が北上し，9，10月と南下するのは，同じく寒帯前線 帯の北上・南下によって説明される。

(3) 5 月から 6 月への急激な大雨日数の増加は, 中緯度季節風域から, 熱帯季節風带の影響下 に入ることによって発生する。

(4) 大雨日数の多い梅雨期と秋雨期の違いは, 梅雨期は熱帯季節風帯に入ることによって 
大雨が多発するが，秋雨期には寒帯前線帯の影響下にある本邦付近に台風が来襲することによ って夏季季節風が流入し，それによって大雨が発生する。寒帯前線帯による現象が西日本に弱 く，東日本で顕著であることから，秋雨期の大雨日数は東日本に多く，西日本で少なくなる。

気象じょう乱が大雨の地域性に対して影響を与兄る与兄方は, (1) 湿潤気流の流入路, (2) 上昇 気流の強さの雨面から考察されなければならない。湿潤気流の流入のしかたと気象じょら乱と の関係については，前節に呿いて太平洋沿岸を対象として諭じ，同地域に特ける大雨の特殊分 布地域の形成を説明した。それゆ光，本節では若干の補足をするにとどめる。

日本海の中央部から北側を低気圧が東進をたは北東進する場合には，温暖前線は本邦を北西 から南東に横切る形になり，湿潤気流は日本海上を西〜西南西の風向をるって日本海沿岸に流 入する。それゆ兄，能登半島に割合多い大雨日数が観测される。ほた，冬季多発域が冬季季節 風によってもたらされていることは論をまたない。

気圧の谷による場合は，湿潤気流は南〜南西の風向を持って流入するので，大雨の発生域は 梅雨前線の場合と同様に，東支那海側や太平洋沿岸の南〜南西側となる。

上昇気流の強さによる大雨の地域的特性は気象じょう乱の経路と強さによって与えられる。

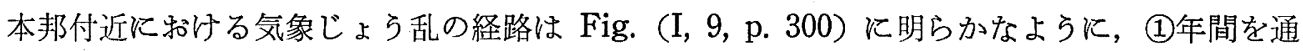
じて最も通過度数の多いのは太平洋沿岸沿いまたはその沖合である。太平洋沿岸の年間多発域 はこれに対応して現われている。（2)次に多いのは，朝鮮海陕あるいは対馬海陕を経て日本海を 北東進する経路で, この場合, 北海道北部を通るるのと, 津軽海陕または東北地方の秋田, 酒 田付近から三陸沖に抜ける経路とに分かれる。このような気象じょう乱の経路によって，東支 那海側の暖候期多発域 および九州北部から山陰地方にかけての割合多い日数の地域が発生し, 秋田付近から宮古付近拈よび北海道の太平洋沿岸の大雨日数が周辺の地域に比して多いことも 説明される。

気象じょう乱の強さによる大雨の地域的特性は, (1) 気象じょう乱の強さが起伏の影響によっ て衰弱すること。(2) 台風などの熱帯低気圧は日本付近の緯度では北上するにつれて衰弱するこ と, (3) 本邦付近の海上を東進する温帯低気圧は, 東進するにつれて発達することなどによって 与党られる。

(1) 気象じょう乱が日本に上陸した場合，急速に中心速度が衰兄て，勢力が減衰する。これ は地形起伏の影響によって, 大気下層の気流が乱れ，気象じょう乱中心に収束する気流の流速 が減衰するためと考兄られる（他に水蒸気補給等の問題もあるが）。九州の東支那海沿岸や太平 洋沿岸の大雨日数が他地域より多いのは，それらの沿岸では陸地の影響を受けない気象じょう 乱飞襲われる回数が多いことも原因となっている。

(2) 台風などの熱帯低気圧は本邦南方洋上で最発達し, 本邦に上陸するとさは盛熟期から衰 弱期に入る時期に当る。台風の大きさが減ずるにつれて強さも減ずるのが普通であり，それゆ え, 台風の上昇気流の影響を受ける範囲は, 北上するにつれて縮小される。これによる大雨日 数への影響は, 緯度が低いほど大雨日数が多くなるといら形で垷われる。

(3) 温带低気圧の日本付近に打訬る急速な発達は, 秋, 冬, 春の 3 季節である。この季節の なかで, 冬季は, 水蒸気圧が非常に少ないので問題にする必要はない。

秋の低気圧は南北に深い気圧の谷を伴い，寒冷 前線によって突風と雷雨を伴うしゅら雨をも たらす。これによる大雨は日本海沿岸の能登半島から若狭湾にかけてと，高田地方に見られる 
が，日本海側では流入水蒸気量との関係で，100 mm 以上の大雨は汪とんどない。

春の低気圧発達の影響は，北海道や東北地方の太平洋沿岸にまで大雨が現われることによっ て示される。

（2）対流不安定解消の地域的集中

低気圧，前線などがその近傍に存在しない時に集中豪雨の発生を見ることがある。その好例 に昭和38年 8 月 17 日, 熊本県の五木村を中心に発生した集中豪雨があげられる。この時には五 木村の五木川第発電所の観測によれば，8 月 16 日には $113.7 \mathrm{~mm} ， 17$ 日には $575.6 \mathrm{~mm}$ といら 日雨量を僱測し，1時間雨量は 17 日 12〜13 時に $140.0 \mathrm{~mm}$ という值を観測している。

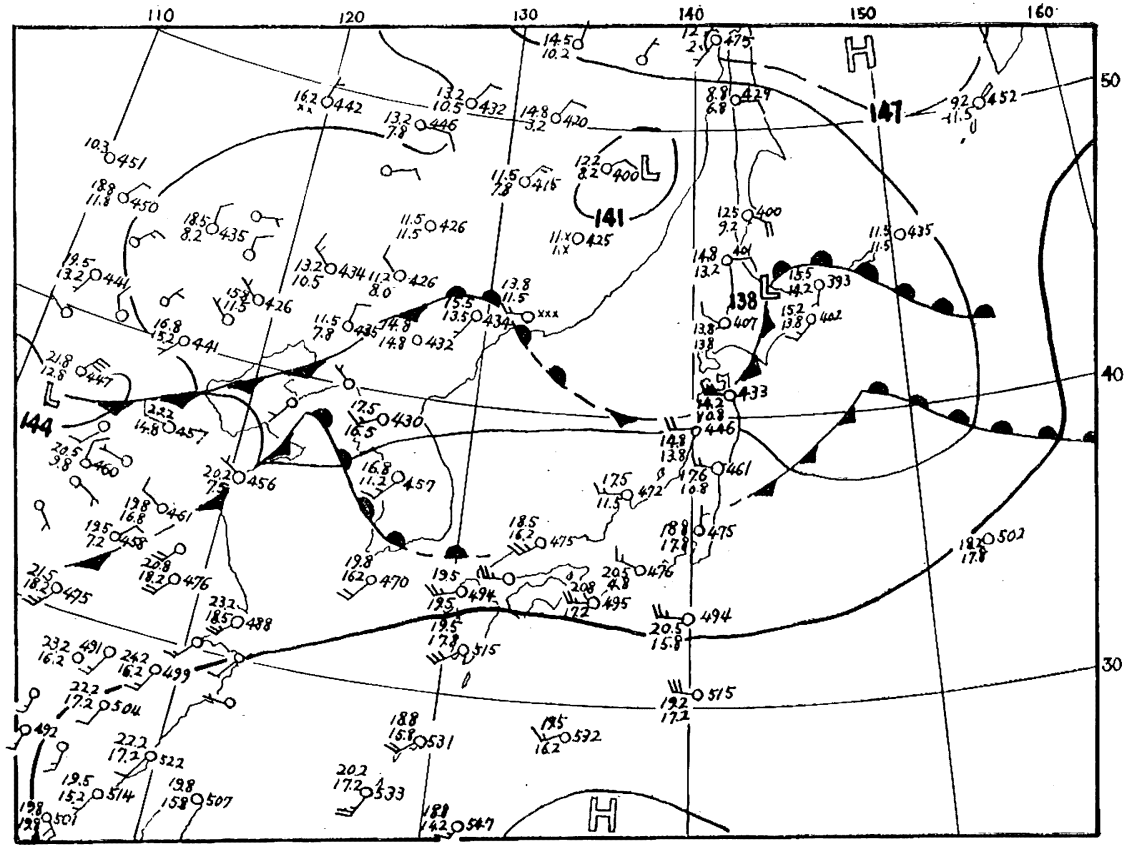

Fig. 18. $850 \mathrm{mb}$ map, 21 L.M.T., 16th Aug. 1963.

8 月 16 日 21 時の $850 \mathrm{mb}$ の天気図を Fig. 18 に示したが，豪雨に関係するよらな気象じょう 乱としては，黄海から朝您海陕を走っていた温暖前線くらいのものであり，西日本は北太平洋 高気圧の縁辺に当っていた。この日の大気成層状態を見るために, 鹿児島, 福岡と, 北太平洋 高気圧の縁辺に当らない名瀬抽よび南大東島の高層資料をTable 8に示した。明らかに九州地方 には湿潤大気が入り込み，効流不安定となっていることがわかる。しかし，この時の雨は，熊 本県で集中豪雨が発生した以外は，被害を発生するような雨が他の地方では降っていない。

対流不安定の解消が雷雲の発達による集中豪雨を発生させることは明らかであるが，それが ぞの地域に何時発生するかについてはまだ明らかでない。夏季雷雨の多発地带である関東地方 内陸部の雷雨は, 同地方が北太平洋高気圧の北縁に当るとさに発生する。るちろん, 北太平洋 高気压の北縁に当るときは，沿海州からオホーツク海に抜ける低気圧があると，低気压の後面 から南東進する寒気の侵入を見て, 寒冷前線が北太平洋高気圧の縁辺に当る地域を通過し, 大 


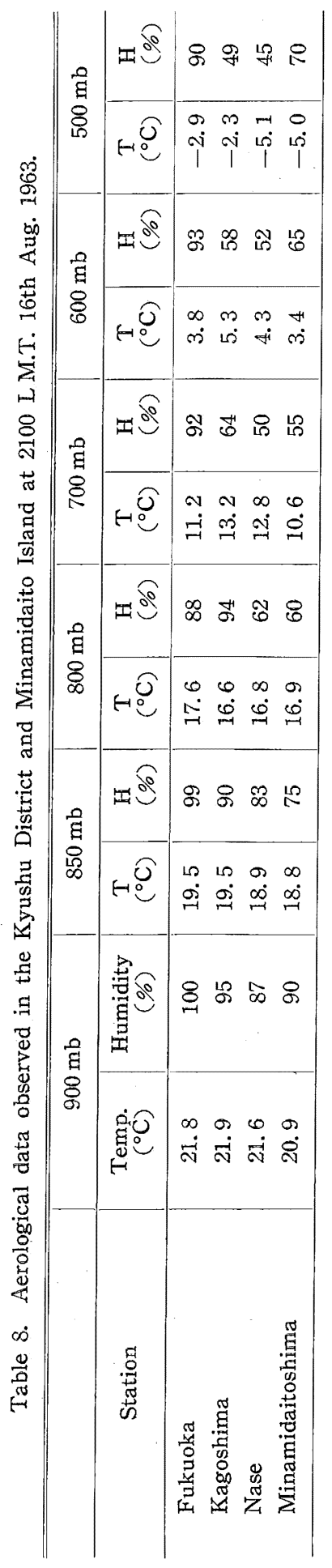


雷雨をひき起こすことも稀ではない。この場合には対流不安定のところに，寒冷前線による上 昇流が加わることになる。

夏期に雷雨の発生し発達する地域は, 内陸山岳地帯から平野部に出る地域である。これは日 射の影響による山谷風牞よび斜面風の発生によって, 気流の収束上昇気流が発生しやすい地形 の亡ころである。関東地方内陸部や中部地方拈よび京都, 伊賀両盆地の 8 月の大雨日数の多い のは雷雨による。

冬季日本海側地方の豪雪は，寒冷気団が日本海を吹き渡って来る間に下層が変質して，成層 が対流不安定化することが一つの主要な原因である。冬季雷多発域は日本海側の豪雪地帯と一 致する。

(3) 地形の影響

地形の降水に対する影響は複雑であり，山岳部の雨量分布は単純な分布をしない。地形の降 水に対する影響を大別すると，次のように分類すこるとがでさる。

(1) 水蒸気輸送の山岳地形による遮蔽

(2) 山岳地形による強制上昇

(3) 地形による気流の強制収束上昇

(4) 起伏が原因となって，2次的な前線面の形成による収束上昇

(5) 気象じょう乱の起伏による衰弱

以上のように分類した影響の仕方が総合されて，実際の降水現象が発生し，大雨日数の地域 性にも複雑さを加兄ているはずである。しかし，気象学の現段階では，まだ，これらの効果を 統一的に与穴て解くまでに至っていない。そして，上記の影響の取り扱い方にしても，(1), (2), (5)ほかは極めて不十分である。

大雨日数の地域分布と関連させながら，上記の各影響について述べることとする。

(1) 水蒸気輸送の山岳地形による遮蔽効果は2.3.1 で論じた。

(2) 山岳地形による強制上昇と降雨との関係,

この関係は岸保勘三郎ら（1956）によって，地形性上昇速度の鉛直分布を導入することによ り, 雨量の量的な地域分布の予報が可能であるという提案がなされ，その後，斉藤直輔，草野 和夫，石原健二，山下洋，野口和則乞の他の人々によって技術化が進められて来た。現在の雨 量予報はこの考方方に根ざしたものである。この考方方では，気流が山岳地帯を吹き通る場合 には気流は山岳の起伏に従って垂直運動をし，迂回するようなことをしない。すなわち，一般 流を $\mathrm{V}$ ，海拔高度を $\mathrm{H}$ とすると，VDH によって雨量の地域分布が決定される。これによる雨 量分布は定性的な地域分布の目安を与兄るが，量的には，特に雨量の多いときは適切な予報值 を与えない。また，量的な地域分布る山岳地形に密着するよらな分布を示さない。これは，山 岳地形の大気運動に対する作用が，VDH で表現されるだけのような単純なものでないことを物 語っている。

しかし，大雨の同一地域区分間に和ける山岳気象官署の大雨日数が，隣接平地官署のそれの 約 1.5 倍であることは，主として，この作用によるものと考兄られる。

(3) 地形による気流の強制収束上昇の効果

この効果については，特に地形による気流の強制収束上昇を中心として，降雨の局地性を論 ずる場合に取り上げられる。この問題は，地形による流入気流の変形を理論的に取り扱うこと 
が困難なので，解析的に，実際の雨量分布を説明するような取り扱い万をしているに過ぎない。 GEIGER の小円丘上に和ける実験観測結果などに見られる微地形上の雨量分布は, 微地形によ る気流の微妙な変化によって降雨分布が発生していることを示す。実際問題として，この問題 を現実の地形に立脚して明らかにするためには，起伏による摩擦によって，主として，大気摩 擦層内に発生する諸現象に対する知識の積み重ねが重要であると考兄る。そして，この効果に よる大雨日数の地域性は，区内観測所以下の細かい観測網によらなければ判明しにくい。それ でも, 冬季の高田や敦賀の大雨日数が隣接地点に比して多いのは, 高田は能登半島と佐渡島で 敦賀は若狭管によって制約された気流の収束域にあたることから説明される。また，尾鷲の大 雨日数が全気象官署中の最多を示しているのる尾驚が湿潤な 南南東〜南東の気流の収束しやす い地形にあたるためである。GEIGER の小円丘の実験観測に示されるような雨量分布を実際の 現象内で確かめることは困難であるが，昭和44年 10 月 22 日に太平洋岸沖を低気圧が通過した際 に三宅島測候所で総雨量 $196.5 \mathrm{~mm}$ という值を観測し, その際, 島内を巡る林道のあちこちに 被害が発生した。その被害分布図を Fig. 19 に示したが，その主風向は測候所の観測によって

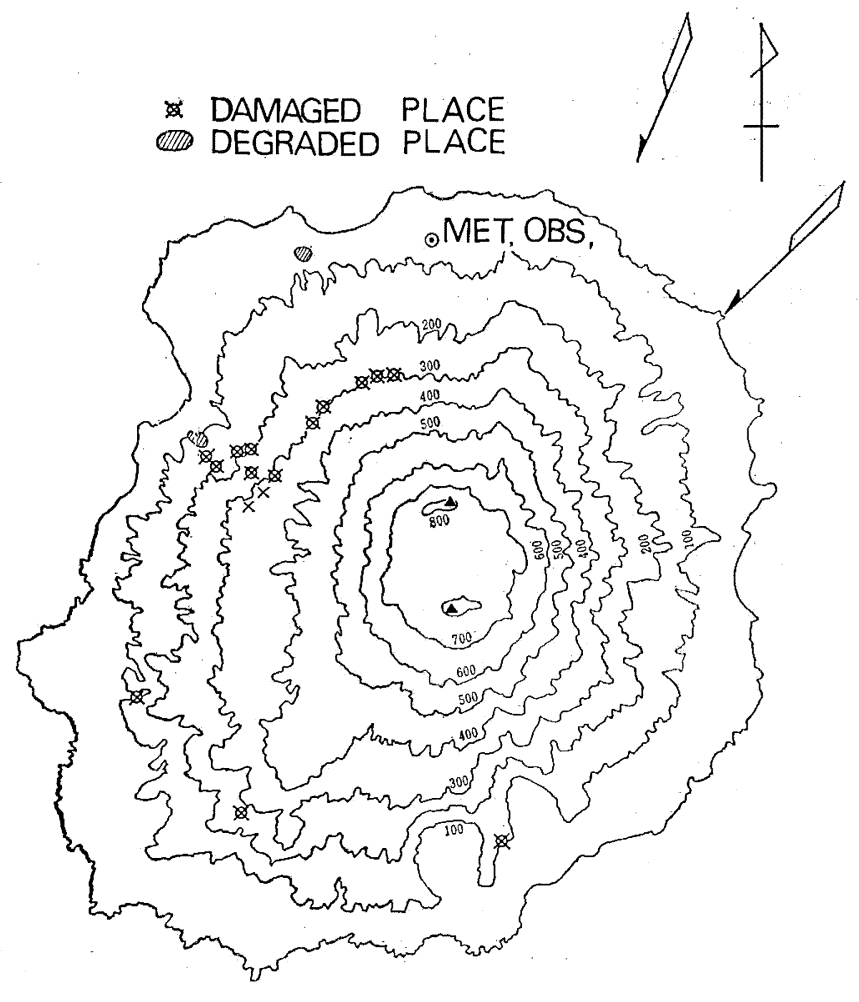

Fig. 19. Areal distribution of the damage to forest roads caused by heavy rainfalls in Miyake Island on 22nd Oct. 1969.

矢印で示した。島はちょうど円錐形をなして扔り，雨量観測綱があれば Geiger の実験観測を 実地に験証する良い資料となったと思われる。被害分布は主風向に対して島の雨側面の風下側 で多発していることを示している。この被害分布から雨量分布も同じ斜面のやや高いところに多 
く降っているものと推定される。（地表地質は一部を残いて，全島にわたってほぼ一様である。）

(4) 起伏が原因となって 2 次的な前線面の形成による収束上昇

この効果は成因によって次の二つに分けることができる。一つは 2.2 .2 で述べた地面粗度の 違いによる力学的なもの (粗度効果) と, 他の一つは熱的原因によるものである。粗度効果につ いてはすでにくわしく論じたので，ここでは，この効果は海岸近傍のみならず，平野部と山岳

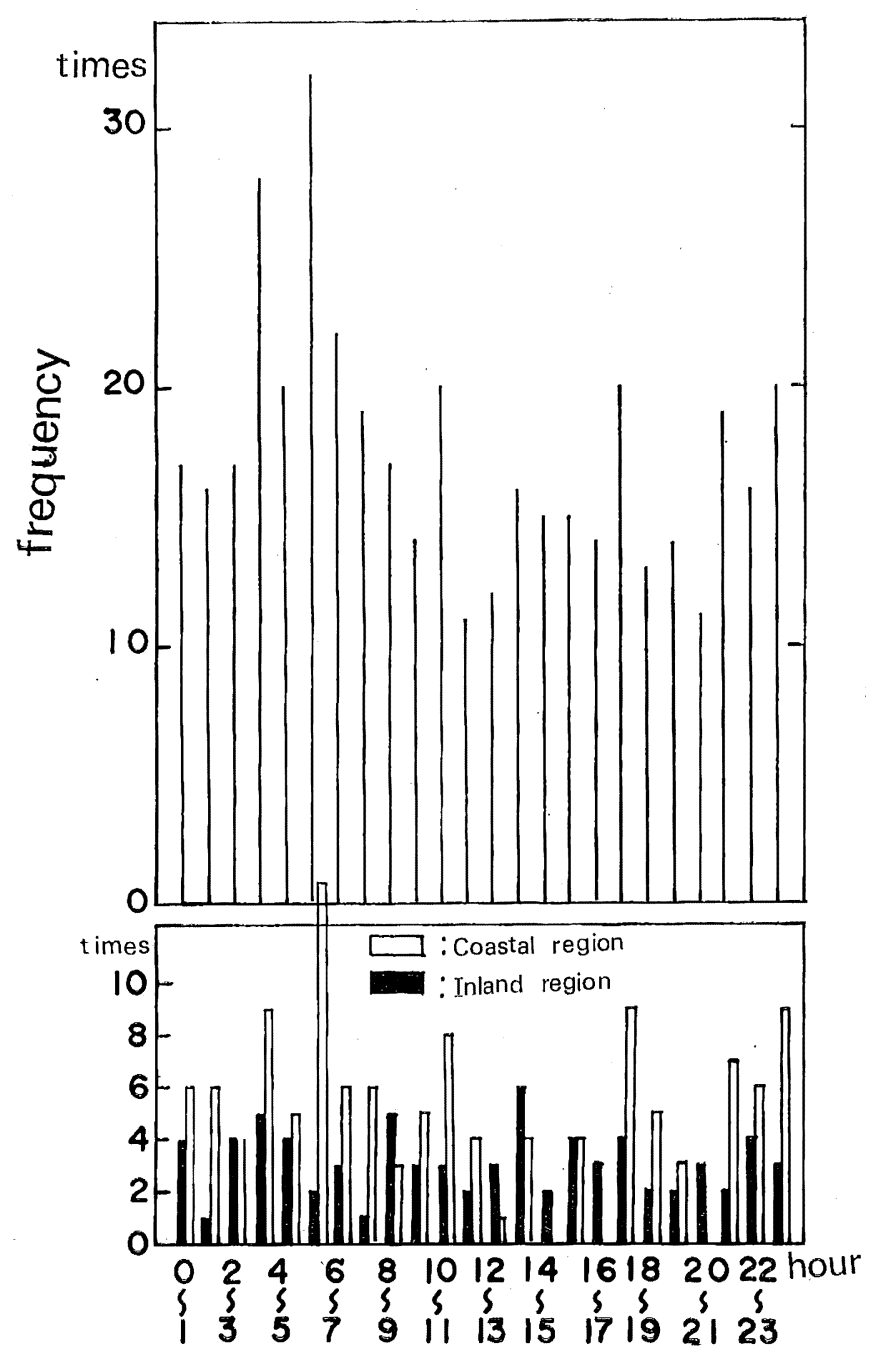

Time

Fig. 20. Diurnal variation of rainfall intensity (expressed by sum of frequencies of max. hourly precipitation amount $\geqq 20 \mathrm{~mm}$ ) at all the stations in Japan, 1951-65.

Upper part indicates the total sum of frequencies at every station; observed max. hourly precipitation $\geqq 20 \mathrm{~mm}$.

Lower part indicates sum of same frequencies observed at stations in coastal and inland regions. 


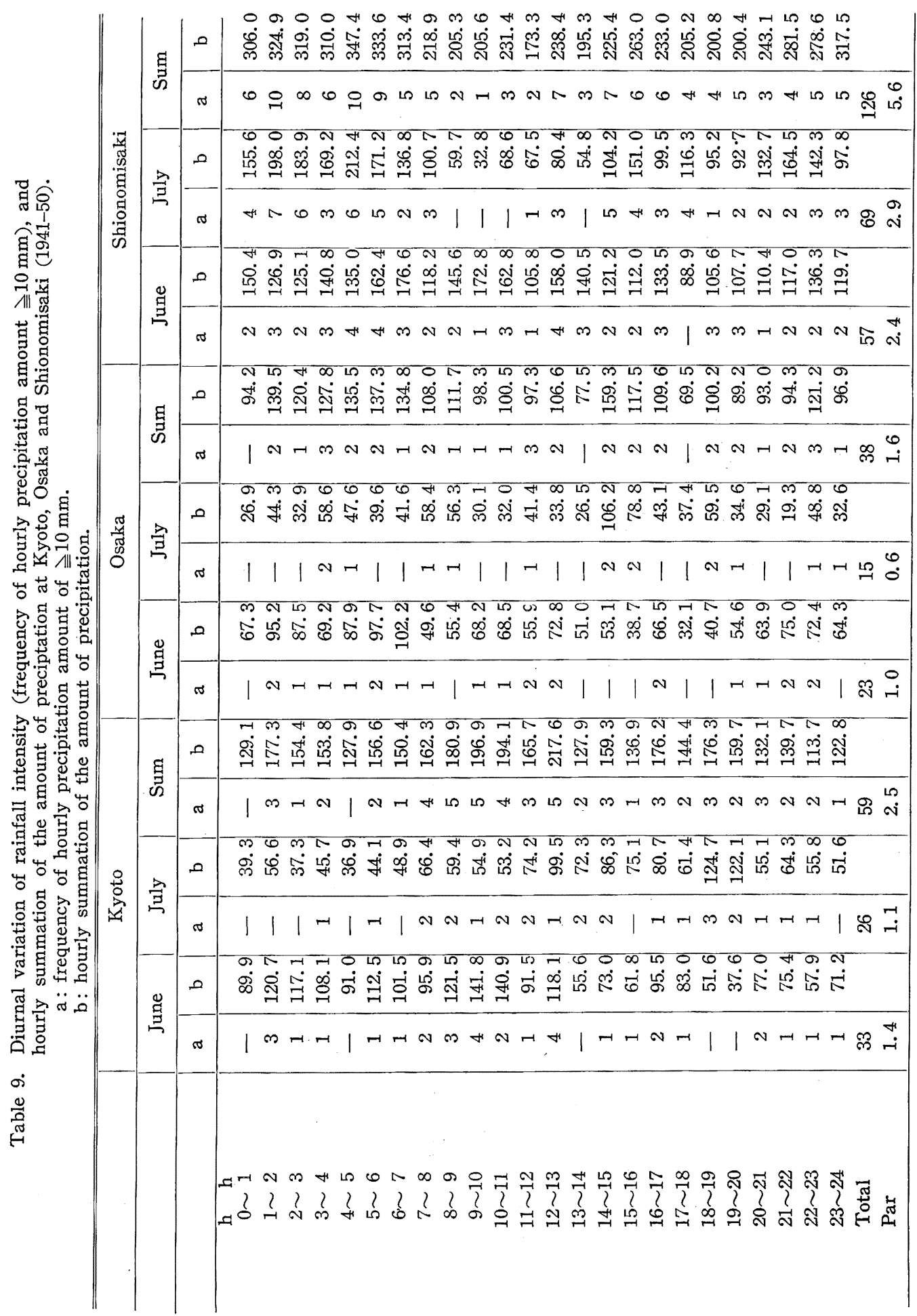


部との境界など，粗度の異なる境界域では何処にでも現われること，現象の強さは粗度の違い の大きいほど大であることを指摘するにとどめ，熱的原因のものについて述べる。

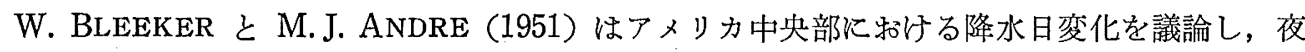
間に降雨度数の多い現象がアメリカ大陸に和ける熱収支の日変化による循環系の変化によって ひき起こされることを明らかにした。また，C.S RAMAGE（1951）は日本を含む極東域の夏に ついて，午前と午後のどちらに降水量の極大が現われるかを検討し，極大の現われる時刻が系 統的であることを見出した。そして，日本について九州の内陸部で曊著な午後の極大，沿岸部 （鹿児島）で顕著な午前となるほか，本州，四国ではやや不明となり，北日本では日変化が小さ いという結論を得ている。

H. LANDSBERG (1950) は, “Physical Climatology”に拈いて, 1 時間雨量の日変化には一 般に地域的特性が現われるが，合計雨量の代りに雨量強度をとったならば，ほとんどの地域で 午後の極大が現われるだろうと結論している。

われわれはこの問題を調べるために，まず「気象要覧」の天候状態の章に揭載の大雨表から， 気圧系の変化の少ない 6,7 月の前線性降雨の場合のみを選び出し, 最多 1 時間雨量が $20 \mathrm{~mm}$ 以 上となった時刻の度数を各地点毎に求めた。統計期間は $1951 〜 65$ 年である。1 時間雨量 $\geqq 20$ $\mathrm{mm}$ という制約から，北日本の地点はほとえど含まれない。Fig. 20 の上段は各時刻別度数を全 地点について集計したもので，5〜 6 時が最多，3〜4 時が次多となり，以下， 6〜7 時， 10〜11 時, 17〜18 時, 23〜24 時の順となっている。これを内陸と沿岸に地域区分して集計すると, 下 段の図のようになる。沿岸地域では5～6時の最多が顕著となり, 次多は 3〜4 時, 17〜 18 時, 23〜 24時で, 日出時刻付近に雨量強度の強い雨が降りやすいことを示している。これに対して，内陸 部は日出時刻前後の極大が消えて 13〜14 時が極大となるが, 日変化が沿岸部ほど顕著ではない。

これをさらに明確に把握するために, 京都, 大阪, 潮岬の 6,7 月の各時刻毎の合計雨量と 1 時間雨量 $10 \mathrm{~mm}$ 以上の度数を 1941〜 50 年の期間について集計した（Table 9)。表から明らかな ょうに, 京都と潮岬とでは明らかに違った日変化を示し, 京都は Fig. 20 の内陸地域の度数分 布々ほぼ類似し，潮岬は同じく沿岸地域のそれに類似の分布をしている。大阪は日変化の幅が 雨量合計, 度数ともに小さく, 中間地帯の性格を帯びている。

これらの事実から見て, LANDSBERG の指摘した一般的傾向とは異なり, 沿岸地域では大雨 時の 1 時間雨量強度にも日出前後の時刻をピークとする度数の日変化が明白に存在する。そし て, 京都, 大阪, 潮岬の日変化が異なるところから, BLEEKER 等の指摘したような局地循環 が大雨時にも加わっていることを示すばかりでなく，気温と海水温の日変化の違いによる水蒸 気補給量の日変化や対流雲に対する放射の影響が加わっているものと思われる。

(5) 気象じょう乱の衰弱については本節の (2) に述べたので省略する。

要約

以上，大雨日数を主要素として，日本に和ける大雨の気候学的特性を明らかにしてきたが， これを要約すると次のようになる。

1) 雨量階級別大雨日数によって，地域分布扣よびその季節変化の実状を明らかにし，これら が気象じょう乱出現の季節変化扣よび水蒸気の流入と関係があることを明らかにした。

2 ) 大雨日数の年間日数と季節変化によって, (1)年間少発型, (2) 年間多発型, (3) 冬季多発型, 
(4) 暖候季多発型の主 4 型社よびそれらの中間型に分けられるが，区内観測所の資料を用いるこ とによって，さらに(3)の冬季多発型と(1)の年間少発型から (2) 年間多発型にいたる中間型をる含 む型との組み合わせ，および梅雨期と台風期との大雨日数の対比，6月と 7 月の大雨日数の対 比によって，さらに地域の細分が可能なることを示した。

3 ) 雨量階級別雨天日数は指数型分布をするが, その分布型は大雨の地域区分毎に異なり, 分 布の統計期間による安定性は 50 年以上で汪安定する。この性質を地域区分に利用すれば，地 域区分をより客観化することが可能である。

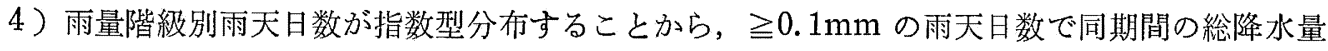
を除した降水密度が地域区分の指標となりらることを理論的に考察し，さらに降水密度と大雨 日数との関係に地域特性があることを実測資料により明らかにした。

5 ）大雨の地域的特性を与える要因について吟味し，次のことを明らかにした。

(1) 水蒸気流入量が大雨の地域的特性を与光るが，水蒸気圧 $13 \mathrm{mb}$ 以上になると水蒸気圧の 増加に比例して, 大雨日数も急増する。水蒸気圧の緯度分布によって大雨日数の緯度分布が 規制される。

(2) 前線や顕著低気圧の度数分布の季節变化によって地域的特性の主要部分が説明される。

(3) 冬季日本海沿岸の大雨多発, 関東地方北部や中部地方内陸部の夏季大雨の多発は大気成 層の不安定化しやすい条件にあることによって説明される。

(4) 同一地域区分間の山岳と平野地点とでは, 山岳地点の大雨日数が約 1.5 倍多く, これは 地形による強制上昇効果が主として働いている。

(5) 西日本の山陰地方, 四国地方特よび紀伊半島の多発地帯が海岸からの距離 15 30km の 間に見られるが，これは海陸の粗度の違いによる粗度効果によって説明される。

(6) 粗度効果による大雨日数の違いは平地と山岳部々の境界域付近にも現われる。瀬戸内海 地方, 長野県長野盆地の少発域は山岳による湿潤気流の遮蔽によって説明される。るた, 瀬 戸内海地方の少発域特よび紀伊半島の多発域の 6 月と 9 月との変化は湿潤気流の流入経路の 変化に帰因する。

(7) 地形による影響のうち，海陸の熱収支などによる局地循環の影響を受けて，大雨時に扣 いても 1 時間雨量強度に日変化が現われ, 海岸地帯では日出前後に極大, 内陸部では午後に 極大を示すような地域的特性を示す。

\section{謝辞}

この論文は東京教育大学の博士論文として作られたものである。この研究に対し，終始適切 かつ懇切なる御指導を賜わった東京教育大学地理学教室の福井英一郎教授に, また諭文作成に 当って懇切な御助言を賜わった同教室の町田・山本・幸田・尾留川の 4 教授に対し，筆者は深 甚なる感謝の意を表するものである。さらに, この研究に対し終始あたたかい御援助を賜わっ た気象研究所台風研究部長須田建博士，友情をもって種々有益なる助言をいただいた測器研究 部第 1 研究室長根本茂博士, 青山学院大学 助教授鈴木栄一博士, 気像研究所調査係長土屋嗾博 士, 法政大学教授吉野正敏博士に深甚なる謝意を表わすとともに, 台風研究部第 2 研究室の 室員諸兄の種々の御援助に対し厚く牤礼を申し上げるものでめる。 
Anderson, E. R., J. L. ANDERson, and J. J. Malciano, 1950: A review of evaporation theory and development of instrumentation. U.S. Navy Electron. Laboratory Rept., Feb. 159.

BALDACCI, Osvaldo, 1952: La intensita medi delle piogge in Italia. Societa Geografica Italiana, Rome, Bolletino, Ser. 8. 5 (3/4), 185-213.

Bergeron, T., 1959: Address of the Honorary Chairman of the Conference, Problems and Methods of Rainfall Investigation. Physics of Precipitation, Geophys. Monograph, No. 5, Washington D.C., Amer. Geophys. Union, 5-30.

BLEEKER, W. and M. J. ANDRE, 1951: On the diurnal variation of precipitation, particularly over central U.S.A., and its relation to large-scale orographic circulation systems. Quart. J. Roy. Met. Soc., I7, 260-272.

Bowen, I. S., 1926: The ratio of heat losses by conduction and by evaporation from any water surface. Phys. Rev., Ser. 2, 27, 779-787.

BRAhAM, R. R., 1952: The water and energy budgets of thunderstorms and their relation to thunderstorm development. J. Met., 9, 227-242.

Chandler, T. J., 1965: The Climate of London. Hutchinson of London Press.

Cresssman, G. P., 1960: Improved terrain effects in barotropic forecasts. Mon. Wea. Rev., 88, 327-342.

FleTCHER, R. D., 1950: A relation between maximum observed point and areal rainfall values. Trans. Amer. Geophys. Union, 31, 344-348.

FuJiTA, T., 1960: Mesometeorological study of pressure and wind fields beneath isolated radar echoes. Proceedings of Eight Weather Radar Conference, Boston, Ame. Met. Soc., 151-158.

1960: A detailed analysis of the Fargo tornadoes of June 20, 1957. Research Paper, No. 42, Washington D.C., U.S.Weath. Bur. 67 p.

FujitA, T. and H. R. BYers, 1960: Model of a hail cloud as revealed by photogrammetric analysis. Techn. Rep., No. 3, Univ. of Chicago, $63 \mathrm{p}$.

Kurashima, A., 1968: Studies on the winter and summer monsoons in East Asia based on the dynamic concept. Geophys. Mag., 34, 145-235.

Landsberg, H., 1950: Physical Climatology. The Pennsylvania State College Press., 122-132.

Morgan, W. A., 1953: Frequency of heavy daily rainfalls in Ireland. Eire. Met. Service, Geophys. Publications, 4(1), $17 \mathrm{p}$.

MURAKAMI, T., 1959: The general circulation and water-vapour balance over the Far East during the rainy season. Geophys. Mag., Tokyo, 29, 131-171.

Neмото, S., 1968: Similarity between Natural Local Wind in the atmosphere and model wind in a wind tunnel. Pap. Met. Geophys., 19, 131-230.

Priestley, C. H. B., 1959: Turbulent transfer in the lower atmosphere. The Univ. of Chicago Press, pp. 19-38.

RAMAGE, C. S., 1951: Diurnal variation of summer rainfall over East China, Korea and Japan. J. Met., 9, 289-299.

ReichmanN, L., 1964: Stark und Dauerniederschläge im nordsächsischen Flachland. Leipzig Deutsches Institut für Länderkunde, Wissen-Schaftliche Veroffentlichungen, n.s. No. 21/22, 219-266.

SAWYER, J. S., 1959: The introduction of the effects of topography into methods of numerical forecasting. Quart. J. Roy. Met. Soc., 85, 31-43.

SchNeIder-Carius, K., 1955: Zur Frage der statistischen Behandlung von NiederschlagsBeobachtungen, Erste Mitt. Zeits. für Met., 9, 129-135.

SutTon, O. G., 1952: Micrometeorology. p. 333. 
TAYloR, R. J., 1962: Small-scale advection and the neutral wind profile. J. Fluid Mechanics, 13, 529-539.

Thornthwaite, C. W., and B. Holzman, 1939: The determination of evaporation from land and water surfaces. Monthly Weath. Rev., 67, 4-11.

江原貞吉, 桃井治三郎, 1915，1917：男体山に拈㺭る気象観測. 森林測候所特別報告, 2, 79-116, 4, 107131.

藤村有雄, 1952：標高と降水量. 東京管区気象台研究会誌, 11, 229-302.

福井英一郎, 1928：我邦に於沙る気候分類に就いて. 地理学評論, 4, 841-853. ，1933：日本の気候区，第 2 報. 地理学評論, 9, 1-17, 109-127, 195-219, 271-300.

- 1934 : 本邦に於ける降水変化量の研究 (第 1 報). 地理学評論, 10, 755-771. , 1938：気候学. 古今書院刊.

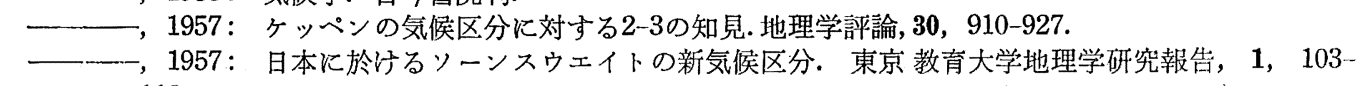
112.

———, 1967：日本に就集中豪雨の研究. 東京教育大学地理学研究報告, 11, 83-95.

岸保勘三郎その他, 1956: 下層大気の気圧場並びに降雨量の量的予報. 硎究時報, 8, 473-494.

石原健二, 1956：雨量の短期予報について. 総理府資源調査会事務局「雨量の観測と予報」, 88-93.

石原健二その他, 1957： Small-scale の雨量予報 (第 1 報). 研究時報, 9, 615-632.

石崎潑雄, 光田寧, 1967：地形々風速. 鋼構造物の耐風設計講習会テキスト, No. 3, p. 14 .

磯崎 優, 1934：ソーソスウエイトの新気候分類と本邦に於けるその適応について. 地学雑誌, 45, 234.

河村 武, 1967：気候学的にみた索雨と地形. 天気, 14, 335-338.

児玉良三, 1954：伊吹山に挌ける山岳雨量 (1). 研究時報, 6, 333-338.

草野和夫その他, 1957：地形性降雨の数值予報. 研究時報, 9, 811-822.

水越允治, 1962：日本に拈ける豪雨の原因. 三重大学学芸学部紀要, 25, 1-17.

- 1962 ：梅雨前線活動に伴ら降水量の分布. 地理学評論, 35, 35-44.

野口和則, 1964: 雨量予報. 気象研究ノート, 15, 372-381.

奥田 穣, 1968： 日本に拈ける大雨の気候学的特性 (第 1 報). Pap. Met. Geophys., 19, 277-308.

斎藤直輔, 1957: 雨量予報序論. 気象協会刊.

関口 武, 1949: 本邦に打ける微雨日数の分布. 地理学評論, 20, 238-237.

- 1949: 日本に打怡るケッペンの気候区. 社会地理, No. 15, 12-16.

関口 武, 1949：本邦付近の降雨日数の分布並びにとれによる気候区分. 地理学評論, 21, 361-367.

ㄴ. 1959: 日本の気候区分. 東京教育大学地理学研究報告, 3, 65-78.

$\longrightarrow$ - 1965: 台風時の雨量分布. 地理学評論, 38, 501-508.

関口 武と協力者, 1965: 東京の大雨の気候学. 東京教育大学地理学研究報告, 9, 143-167.

関口 武, 井上修一, 1967: 関東地方の大雨の気候学. 東京教育大学地理学研究報告, 11, 37-52.

土屋正孝, 1960：わが国に特ける雨の強さならびにとれによる地域区分. (未印刷)

内海德太郎, 1959: 降水量分布と代表地点. 気象研究ノ一ト, 10, 111-124.

和達清夫 (監修), 1958: 日本の気候. 東京堂刊.

矢沢大二, 1949：本邦各地の雨量推移の特性について. 地理学評論, 22, 274-279.

吉田作松, 1951：岩手山に和仔る雨量の高度分布. 研究時報, 3, 364-367.

吉野正敏, 1960：日本に打汀る雨量最大観測值・雨量一時間曲線・雨量強度一時間曲線の特性ととの分布. 気象集誌, 38, 27-46.

- 1961 : 小気候. 地人書館刊.

農林水産技術会議, 1960：日本の気候分類図集.

\title{
日本における大雨の気候学的研究
}

\author{
奥 田穣
}

日本に持ける大雨を日雨量階級別の度数を用いて, まず, その地域特性を統計的に明らかにし, 次に, 地 域特性を与える諸要因について動気候学的立場から考察を行なった。 
大雨の地域特性は，その大勢は日本列島上拈よびその周辺に現われる気象じょう乱の出現度数の地域分布 牤よびその变化と対応して現われる。

大雨の出現度数拉よびその年変化から大雨の気候区分を行ならことは可能で，西日本については区内観測 所資料を用いて地域区分の細分を試みた。との結果は，福井（1933）による気候区分とよく対応する。

日雨量階級別度数分布が指数関数型分布を示すことから，降水密度が大雨度数の良い指標となりらること を理論的にも解析的にも明らかにしたが，その関係は大雨の気候区分によって相違がある。

大雨の地域特性を与える要因には, 流入水蒸気量の多㙞特よび地域的に持続する上昇気流の存否が大別し てあげられる。

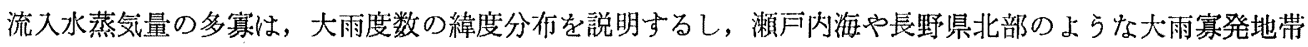
は流入水蒸気量の山岳地形による遮蔽効果によって説明される。また, 紀伊半島を例として, $850 \mathrm{mb}$ 面の風 向度数と半島の東西両側の大雨度数の相違との関係を明らかにした。

地域的に持続する上昇気流を与兄る要因については，気象じょら乱をれ自体によるるのと，地形に上る影 響とに分けて考察される。地形による影響はさらに力学的作用と, 蓺学的作用とに細分されるが，特に，海 岸地帯や, 山岳部縁辺に現われる大雨多発地帯については, 地表面の粗度効果による収束帯の形成が取り上 け゚られたし, 蓺的な作用として, 大雨時に和ける 1 時間雨量強度の日変化が海岸で日出, 内陸では午後に極 大を持って現われ，この現象は，大雨時にる熱収支の日変化の影響が降雨発生過程に加わっていることを示 与ものとして指摘される。 